In cooperation with the U.S. Environmental Protection Agency

\title{
Sources of Polychlorinated Biphenyls to Devils Swamp Lake Near Baton Rouge, Louisiana
}
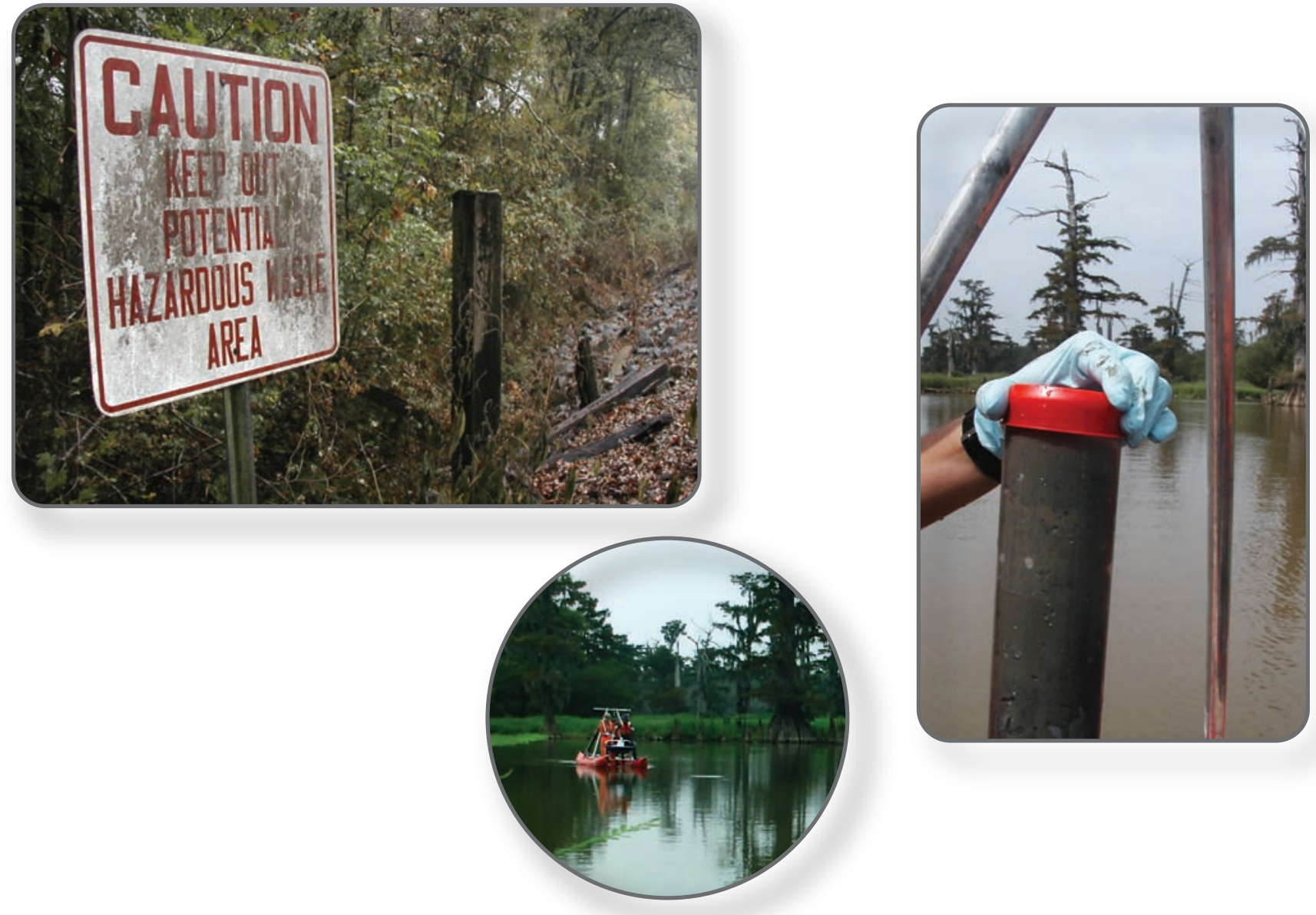

Scientific Investigations Report 2006-5301 


\section{Cover}

Top left: Sign near wastewater drainage ditch that enters Devils Swamp Lake (October 2004).

Top right: Capping gravity core collected from Devils Swamp Lake (October 2004).

Bottom: Portable watercraft on Devils Swamp Lake (October 2004). 


\section{Sources of Polychlorinated Biphenyls to Devils Swamp Lake Near Baton Rouge, Louisiana}

By Peter C. Van Metre, Jennifer T. Wilson, and Briant A. Kimball

In cooperation with the U.S. Environmental Protection Agency

Scientific Investigations Report 2006-5301 


\title{
U.S. Department of the Interior DIRK KEMPTHORNE, Secretary
}

\author{
U.S. Geological Survey \\ Mark D. Myers, Director
}

\section{U.S. Geological Survey, Reston, Virginia: 2006}

For sale by U.S. Geological Survey, Information Services

Box 25286, Denver Federal Center

Denver, CO 80225

For more information about the USGS and its products:

Telephone: 1-888-ASK-USGS

World Wide Web: http://www.usgs.gov/

Any use of trade, product, or firm names in this publication is for descriptive purposes only and does not imply endorsement by the U.S. Government.

Although this report is in the public domain, permission must be secured from the individual copyright owners to reproduce any copyrighted materials contained within this report.

Suggested citation:

Van Metre, P.C., Wilson, J.T., and Kimball, B.A., 2006, Sources of polychlorinated biphenyls to Devils Swamp Lake near Baton Rouge, Louisiana: U.S. Geological Survey Scientific Investigations Report 2006-5301, 50 p. 


\section{Contents}

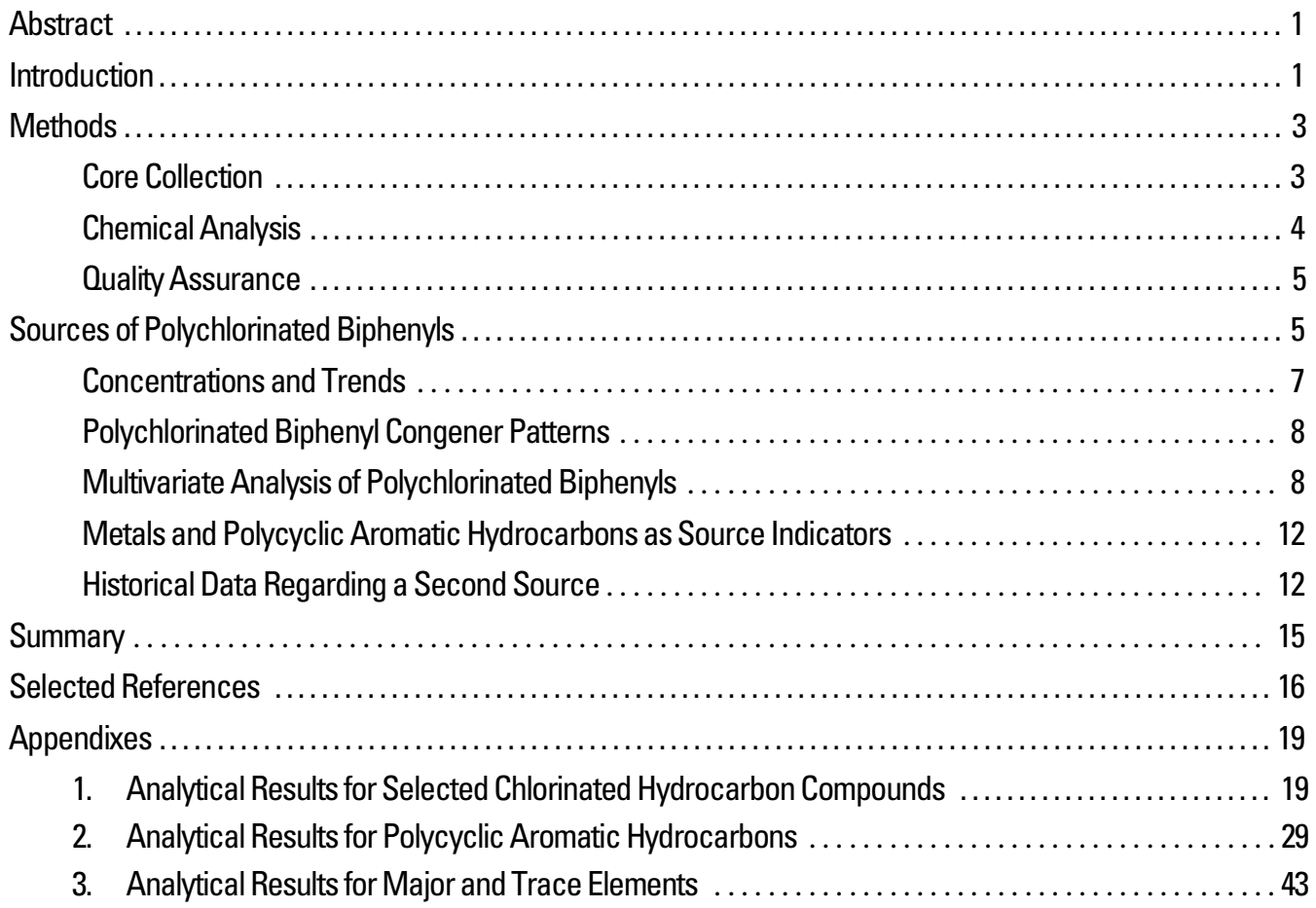

\section{Figures}

1. Aerial images of Devils Swamp Lake near Baton Rouge, Louisiana, showing (A) lake in relation to surrounding features and (B) approximate locations of sites sampled

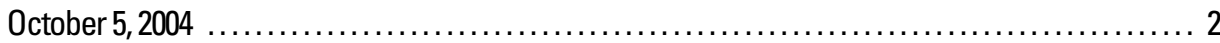

2. Photograph showing core DSL.5 collected from Devils Swamp Lake, Louisiana, October 5,

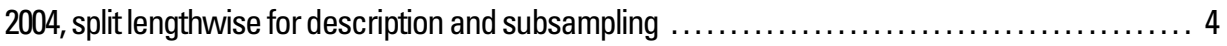

3-7. Graphs showing:

3. Concentrations of polychlorinated biphenyls (PCBs) in Devils Swamp Lake, Louisiana, cores - comparison of immunoassay screening results and laboratory analyses using gas chromatography with electron capture detection (GC-ECD)

4. Polychlorinated biphenyl (PCB) congener patterns in various groups of bed sediment samples collected in and near Devils Swamp Lake, Louisiana .... 9

5. Temporal shifts in relative concentrations (to total) of polychlorinated biphenyl (PCB) Aroclors in Devils Swamp Lake, Louisiana, bed sediments

6. Factor loadings determined using proportions of polychlorinated biphenyl (PCB) congeners in samples from Devils Swamp Lake, Louisiana .... 11

7. Temporal trends in concentrations of selected metals, the sum of polychlorinated biphenyl congeners $\left(\Sigma P C B_{C}\right)$, the sum of selected polycyclic aromatic hydrocarbons $\left(\Sigma \mathrm{PAH}_{\mathrm{SQG}}\right.$ ), and the PAH source ratio (PAH 2+3/comb ratio) in cores DSL2, DSL.4, and DSL.5, Devils Swamp Lake, Louisiana 
8. Aerial images of Devils Swamp Lake, Louisiana, showing concentrations of $(A)$ the sum of polychlorinated biphenyl Aroclors $\left(\Sigma \mathrm{PCB}_{\mathrm{A}}\right)$ and $(\mathrm{B})$ the sum of 13 polycyclic aromatic hydrocarbon compounds used for the probable effects concentration $\left(\Sigma P A H_{S Q G}\right)$ in U.S. Geological Survey (USGS) core samples dated as mid-1980s and in grab samples collected in 1992 by PRC Environmental Management, Inc

\section{Tables}

1. Compound type, common name, abbreviation, and registry number for chlorinated

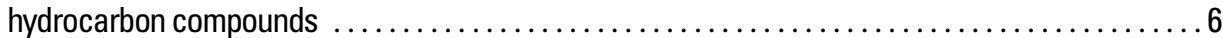

2. Scores for factors representing three end-members determined using EQ-mode factor analysis of polychlorinated biphenyl (PCB) congener concentrations in sediment from Devils Swamp Lake, Louisiana

3. Compositional loadings of three end-members based on EQ-mode factor analysis for sediment samples from Devils Swamp Lake, Louisiana 


\title{
Sources of Polychlorinated Biphenyls to Devils Swamp Lake Near Baton Rouge, Louisiana
}

\author{
By Peter C. Van Metre, Jennifer T. Wilson, and Briant A. Kimball
}

\section{Abstract}

Devils Swamp Lake near Baton Rouge, Louisiana, created in 1973 by dredging in Devils Swamp along the Mississippi River, is contaminated with polychlorinated biphenyls (PCBs) from historical industrial discharges. This study involved the investigation of the occurrence, distribution, and sources of PCBs in the lake, including the possible historical contribution of PCBs from a hazardous-chemical disposal facility by way of a wastewater drainage ditch that was used from 1971 to 1993. Six bed sediment cores from the lake and three bed sediment grab samples from the drainage ditch were collected; 61 subsamples from selected intervals in five of the six cores and the three grab samples from the ditch were analyzed for PCBs using an immunoassay screening method. Sixteen of the core subsamples and one ditch sample were analyzed for organochlorine pesticides, PCBs, polycyclic aromatic hydrocarbons (PAHs) (15 samples), and major and trace elements. PCB congener profiles and a factor analysis of congener composition indicate that PCBs in sediment from the drainage ditch and in lake sediment deposited near the canal since the mid-1980s are similar, which indicates the disposal facility, by way of the wastewater drainage ditch, is the source of the PCBs. Sediment from several hundred meters down the lake to the west, near where Bayou Baton Rouge enters the lake, had a different PCB composition and in a sample deposited in the early 1980s, a much higher concentration, indicating a second source of PCBs in the watershed of Bayou Baton Rouge. Large differences in PAHs and metals between sediment near the ditch and sediment near Bayou Baton Rouge support this conclusion. The identity of the Bayou Baton Rouge source(s) cannot be established using available data. The short duration and relatively high concentrations of PCBs from the bayou source indicate either a spill or a floodrelated release-there was a large flood on the Mississippi River in 1983. Older (deeper) samples from cores near the drainage ditch (dated as deposited before the mid-1980s) had PCB compositions that indicate a mixture of sources (Bayou Baton Rouge and the drainage ditch). Elevated PCB concentrations in sediment from the drainage ditch and cores from near the mouth of the ditch in recent (post-2000) samples indicate that some PCB inputs from the ditch might still be occurring.

\section{Introduction}

Polychlorinated biphenyls (PCBs) were first synthesized in the laboratory in 1929, and an estimated $6.8 \times 10^{8}$ kilograms were produced in the United States prior to cessation of production in 1977 (U.S. Environmental Protection Agency, 2006). PCBs were used in hundreds of commercial and industrial applications, including as plasticizers, as hydraulic lubricants in gas turbines and vacuum pumps, in heat-transfer systems, and as dielectric fluids in electrical transformers. PCBs are, in general, highly resistant to chemical or biological transformation. Because PCBs are persistent in the environment and strongly hydrophobic, sediment deposited in lakes and reservoirs can provide a historical record of PCB contamination in the watershed. Sediment cores have been used to reconstruct waterquality histories in a variety of hydrologic and land-use settings (Davis, 1980). PCBs pose a threat to biota in aquatic systems because they are persistent, bioaccumulative, and toxic (U.S. Environmental Protection Agency, 1997).

Devils Swamp Lake is on the north side of Baton Rouge, La., along the east bank of the Mississippi River (fig. 1). The lake was constructed by dredging in 1973, and the material removed was used to reinforce the levee along the north and west sides of the Baton Rouge Harbor (U.S. Environmental Protection Agency, 2004a). During flooding, the lake and surrounding swamp are inundated by water from the Mississippi River. A hazardous-chemical disposal facility is northeast of the lake. The facility began operating in 1971 and discharged wastewater to the north end of Devils Swamp Lake through a ditch. Presumably, discharges during 1971-73 were to the area of the wetland that was dredged to form the upper (east) end of the lake. The wastewater drainage ditch remained in use until 1993 when a discharge pipe to the Mississippi River was installed and permitted. Runoff from the facility also entered Devils Swamp upstream from the lake through one or more natural drainage areas (U.S. Environmental Protection Agency, 


\section{Sources of Polychlorinated Biphenyls to Devils Swamp Lake Near Baton Rouge, Louisiana}

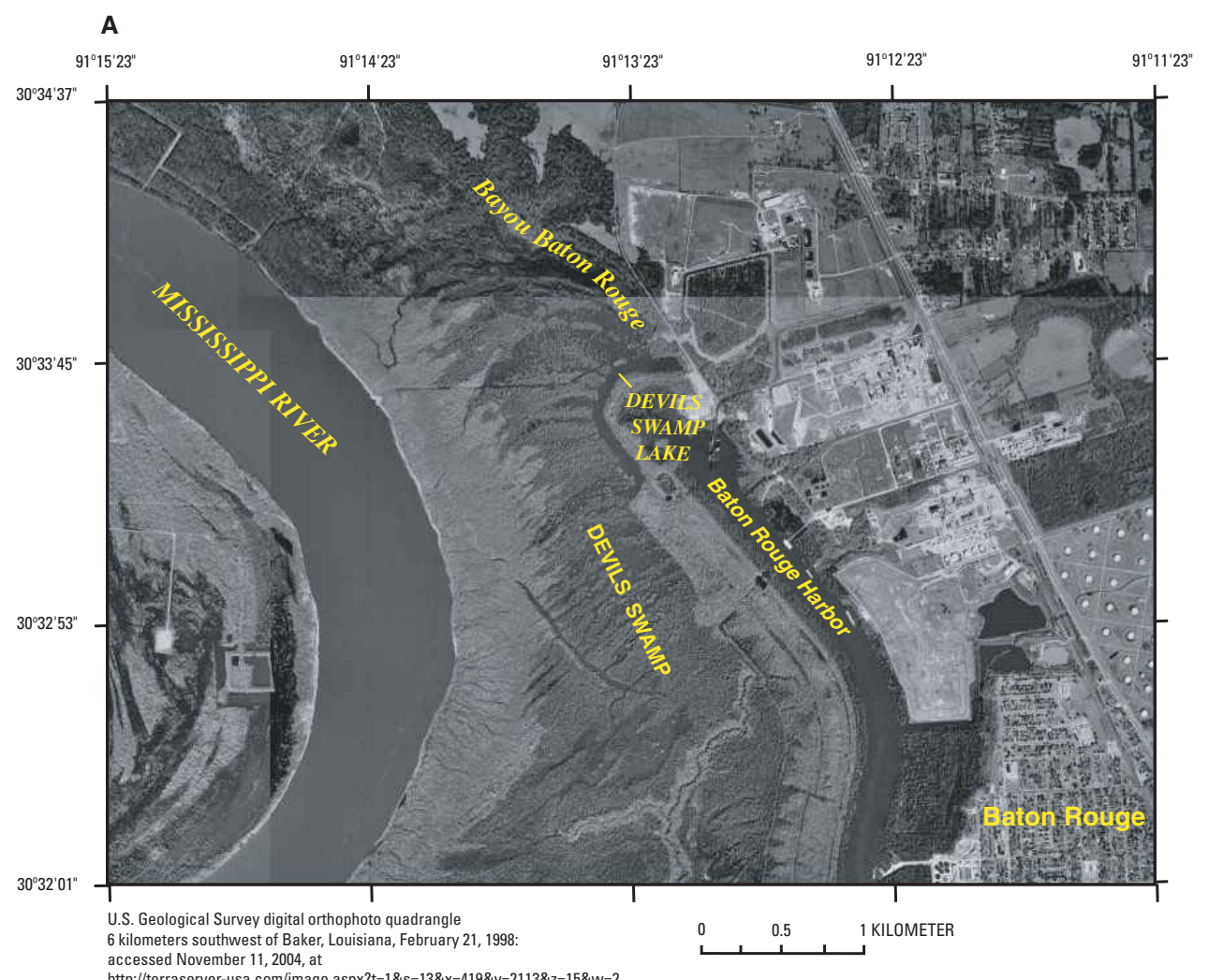

http://terraserver-usa.com/image aspx?t=1\&s=13\&x=419\&y=2113\&z=15\&w=2

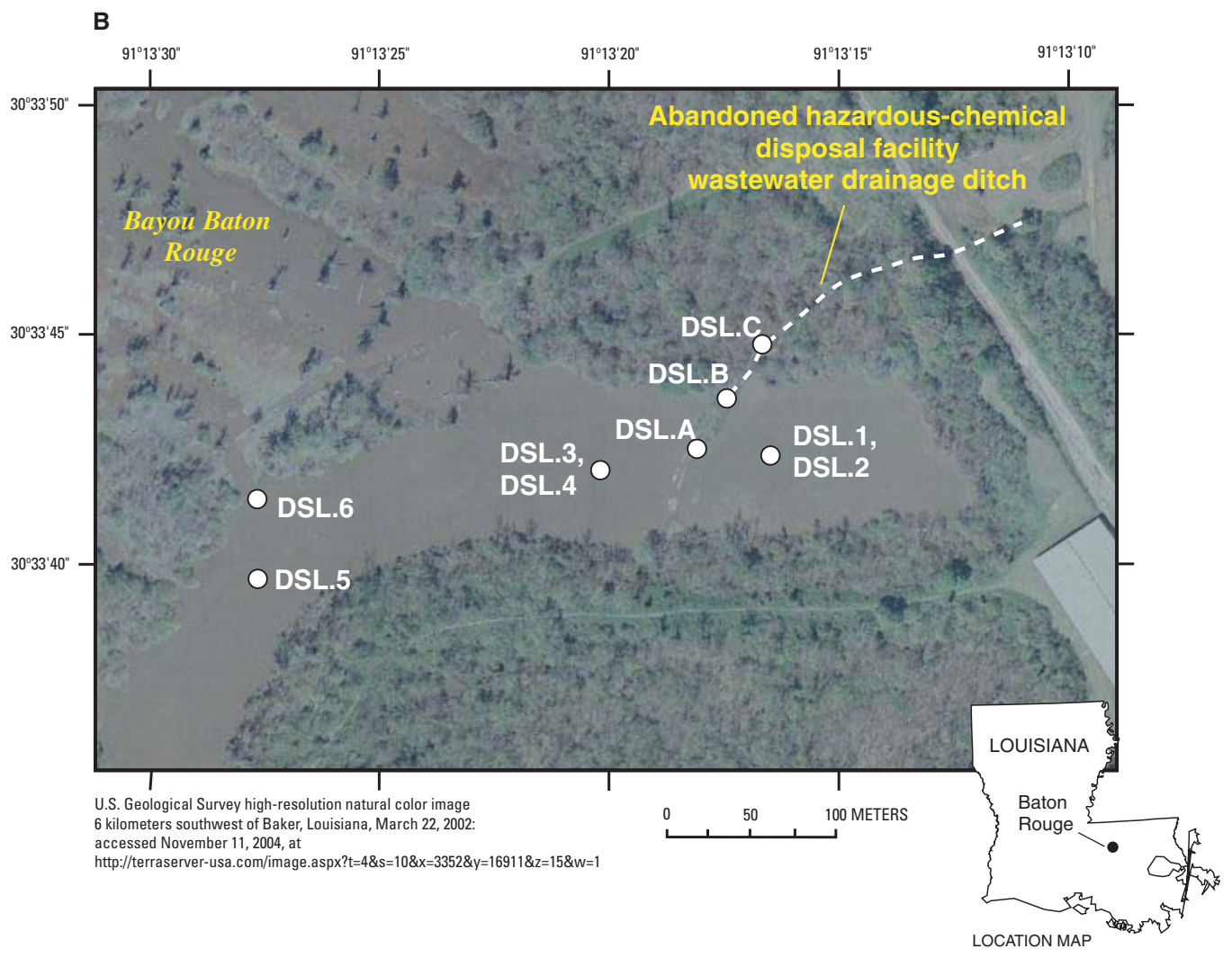

Figure 1. Aerial images of Devils Swamp Lake near Baton Rouge, Louisiana, showing (A) lake in relation to surrounding features and (B) approximate locations of sites sampled October 5, 2004. 
2004b). Sediment sampling done by the Louisiana Department of Environmental Quality and the U.S. Environmental Protection Agency in 1986 yielded PCBs in Devils Swamp Lake and in the wastewater drainage ditch (U.S. Environmental Protection Agency, 2004a; PRC Environmental Management, Inc., 1993).

The objective of this study, done by the U.S. Geological Survey (USGS) in cooperation with the U.S. Environmental Protection Agency, was to determine if PCBs in all or parts of Devils Swamp Lake are from historical discharges into the lake from the hazardous-chemical disposal facility wastewater drainage ditch. Attribution was attempted on the basis of (1) the spatial and temporal record of PCB inputs preserved in bed sediments in relation to the effluent discharge history of the disposal facility, (2) the chemical signature of PCBs preserved in bed sediment in the lake in comparison to the chemical signature of PCBs in bed sediment from the wastewater drainage ditch, and (3) relative concentrations of other anthropogenic contaminants (polycyclic aromatic hydrocarbons [PAHs] and trace elements [metals]) preserved in bed sediments as indicators of anthropogenic sources.

The purpose of this report is to document the findings of the study and describe sources of PCBs to Devils Swamp Lake. Bed sediment samples were collected from the drainage ditch, and bed sediment cores were collected from several sites in Devils Swamp Lake near where the drainage ditch enters the lake and down-lake to the west near where Bayou Baton Rouge enters the lake. Cores were split lengthwise, visually described, photographed, and selected intervals of the cores were subsampled. Sixty-one core subsamples and three drainage ditch bed sediment samples were analyzed for PCBs using an immunoassay screening method. On the basis of those results, 16 of the core subsamples and one drainage ditch bed sediment sample were analyzed for PCB congeners and other organic and inorganic constituents in the laboratory and interpreted to evaluate historical sources of PCBs to the lake.

\section{Methods}

Six bed sediment cores were collected from four sites in Devils Swamp Lake and grab bed sediment samples were collected from three sites in the drainage ditch on October 5, 2004 (Van Metre and Wilson, 2004). Cores DSL.1 and DSL.2 were collected near each other from a site in the upper (east) end of the lake, east of the low spit of land where the drainage ditch enters the lake (fig. 1). This spit separates the upper end from the main body of the lake during low water. Cores DSL. 3 and DSL.4 were collected near each other at the approximate lake center and about the same distance west of the spit as the locations of DSL.1 and DSL. 2 were to the east or about 50 meters. Core DSL.5 was collected from a location about 300 meters southwest of where the drainage ditch enters the lake at the approximate lake center. Core DSL.6 was collected north of DSL.5, near the shore in front of a channel entering the lake from the large area of wetlands to the north and where Bayou Baton Rouge enters the lake. The bayou is a 248-squarekilometer watershed to the north and west of the lake. Three bed sediment samples were collected from the drainage ditch: DSL.A, on the spit of land about 40 meters into the lake from where the canal crosses the north shore of the lake; DSL.B, about even with the north shore of the lake; and DSL.C, about 40 meters upstream from the north shore of the lake. The spit of land containing the drainage ditch extends across the lake and the remains of the ditch banks and bottom were covered with vegetation during sampling in 2004 . The spit probably represents the pre-dredging level of the wetland prior to lake construction in 1973. Except during floods, the spit is exposed and probably contained ditch flow as far as the middle of the lake, where erosion of the ditch banks was apparent in 2004. All three ditch samples were of the top 10 to 15 centimeters $(\mathrm{cm})$ of bed sediment at the center of the 3- to 4-meter-wide canal and were scooped directly into glass jars.

\section{Core Collection}

Cores were collected using a $6.7-\mathrm{cm}$-diameter push corer with a polybutyrate liner attached to a check valve and an aluminum rod that is pushed into the lake bed sediment to obtain a core. The liners were washed with phosphate-free detergent and tap water prior to use and only used once. Cores were pushed into the bed sediment until firm sediment prevented further penetration. Sediment recovery ranged from 51 to $148 \mathrm{~cm}$. Cores were returned to the USGS office in Austin, Tex., where they were sampled the following day. Each core was split lengthwise by cutting most of the way through the liner on opposite sides using a circular saw, cutting the rest of the way through using a utility knife, then slicing the sediment with a washed, Teflon-coated blade. Each core was photographed (fig. 2) and described. Description included color, texture, odor, and presence or absence of visible organic detritus, biota, and gas pockets. Subsamples of selected intervals from the cores were transferred to baked-glass or Nalgene jars for chemical analysis. Intervals were selected either using a constant length (for example, $5 \mathrm{~cm}$ ) or on the basis of distinct changes in color and odor. Color changes were mostly alternating light (olivegray) and dark (black) bands in the cores thought to correspond to less- and more-contaminated sediments, respectively. Sediments, especially in the dark layers, had a hydrocarbon odor. Subsamples for chemical analysis were scooped from the open liner using a Teflon-coated spatula taking care to not include material in contact with the walls of the liner. Subsampling tools were cleaned between each sample by rinsing with tap water, washing with phosphate-free detergent, and rinsing again with tap water. A subsample for analysis of organic compounds was transferred to a baked-glass jar and chilled pending shipment to the laboratory. A subsample for analysis of major and trace elements was transferred to a polypropylene jar, frozen, freeze-dried, and ground to a fine powder before shipment to the laboratory. 


\section{Sources of Polychlorinated Biphenyls to Devils Swamp Lake Near Baton Rouge, Louisiana}

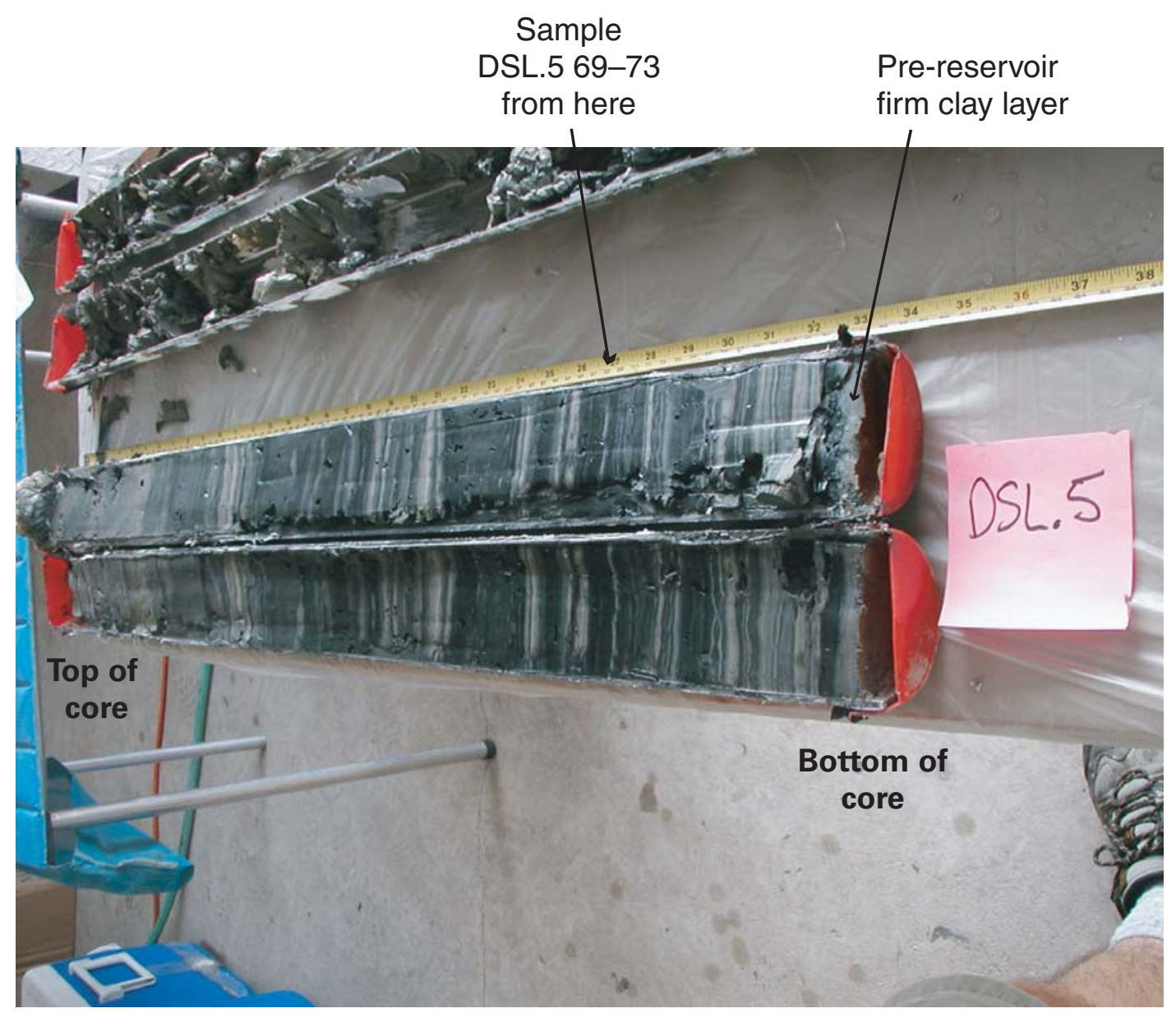

Figure 2. Core DSL.5 collected from Devils Swamp Lake, Louisiana, October 5, 2004, split lengthwise for description and subsampling.

\section{Chemical Analysis}

Selected sediment samples were analyzed for total PCBs using the RaPID Assay ${ }^{\circledR}$ immunoassay kit (Strategic Diagnostics, Inc., 2004) as reported in Van Metre and Wilson (2004). A subset of samples analyzed by immunoassay were analyzed for organochlorine pesticides (OCs), PCBs, PAHs, and major and trace elements at the USGS National Water Quality Laboratory (NWQL).

Organochlorine pesticides, PCBs, PAHs, and alkyl-substituted PAHs (alkyl-PAHs) were extracted, isolated, and analyzed using the procedures of Noriega and others (2003) and Olson and others (2003). Briefly, wet bed sediment was extracted overnight with dichloromethane in a Soxhlet apparatus. The extract was reduced in volume and filtered. Two aliquots of the sample extract were quantitatively injected into a polystyrene-divinylbenzene gel permeation column and eluted with dichloromethane to remove sulfur and partially isolate the target analytes from coextracted high-molecular-weight interferences such as humic substances. The first aliquot was passed through a silica column cleanup step and then analyzed for PAHs and alkyl-PAHs by capillary-column gas chromatography with detection by mass spectrometry. Parent PAHs were identified and quantified by comparison to authentic standards. Individual alkyl-PAHs were quantified when authentic alkyl-substituted standards were available. The multiple isomeric alkyl-PAHs were quantified from mass chromatograms as the sum of all isomers at each alkylation level (C1-naphthalenes, C2-naphthalenes, and so forth). When authentic alkylsubstituted standards were unavailable, a parent PAH was used as the standard for quantification. Nineteen parent PAHs, 10 specific alkyl-PAHs, and the homologous series of alkylPAHs were determined. The second aliquot was further split into two fractions by combined alumina/silica adsorption chromatography followed by a micro Florisil column cleanup step prior to determination of the OCs and PCBs by dual capillarycolumn gas chromatography with electron capture detection (GC-ECD). The OCs were reported as individual compounds. PCBs were reported as individual Aroclor (1016+1242, 1254, or 1260) equivalents (Noriega and others, 2003). 
For this study, fraction 1 (PCB fraction) of the second aliquot was analyzed for 27 (of 209 possible) PCB congeners (table 1) along with the other fraction 1 analytes during GC-ECD analysis. The congeners chosen for this analysis were some of the more dominant congeners in the most widely used Aroclors (1016, 1242, 1254, and 1260). In addition to the dominance of these congeners, potential co-elution issues and signal response for this analytical method also was considered. A series of dilutions of a custom mixture containing the 27 selected PCB congeners was used to make the calibration standards. Calibration standards were prepared at four levels and a minimum of three points was used for the calibration curves. An additional congener solution was prepared at a concentration that was mid-range on the curve and was used as a check standard to verify the calibration curve. The method reporting level (MRL) for PCB Aroclors is 5 micrograms per kilogram $(\mu \mathrm{g} / \mathrm{kg})$. An MRL has not been established for individual congeners because the analytical method is new; however, it is thought to be conservatively about $1 \mu \mathrm{g} / \mathrm{kg}$. Concentrations less thanthe MRL were reported when the analyst was confident in the detection; those concentrations are identified in the tables of analytical results as estimated (E) (appendixes 1,2). The quantification of individual congeners is thought to be more precise than the Aroclor equivalents; hence, the sum of the 27 congeners $\left(\Sigma \mathrm{PCB}_{\mathrm{C}}\right)$ is used for most interpretations. A comparison of all samples indicated that $\Sigma \mathrm{PCB}_{\mathrm{C}}$ accounted for 67 percent (mean), \pm 10 percent ( 1 standard deviation), of the sum of the Aroclors $\left(\Sigma \mathrm{PCB}_{\mathrm{A}}\right)$.

Samples for analysis of major and trace elements were completely digested using a mixture of hydrochloric-nitricperchloric-hydrofluoric acids and analyzed by inductively coupled plasma/mass spectrometry (Briggs and Meier, 2003). Mercury was analyzed by cold vapor atomic absorption spectrometry (Arbogast, 1996).

\section{Quality Assurance}

Quality assurance for chlorinated hydrocarbon compounds and $\mathrm{PAH}$ analyses was provided by analyzing laboratory duplicate, analytical blank, and spiked samples (appendixes 1,2), and by monitoring recovery of surrogate compounds. The NWQL analyzes one duplicate, one analytical blank, and one spiked sample with each set of 12 environmental samples (not necessarily all from the same study) (Noriega and others, 2003; Olson and others, 2003). Two duplicate samples analyzed for this study (both for OCs and PCBs, although PCB congeners were not reported for one of the two) had a median relative percent difference (RPD) of 8.8 percent. There were no detections in the blank samples. Two blank samples (set numbers 200504607 and 200504608) were ruined during preparation at the laboratory, and no results were reported. Median spike recoveries for sample sets that included samples from this study were 84 percent for OCs and PCBs and 72 percent for PAHs. Spike recoveries met control limits in 78 percent of the $\mathrm{OC}$ and PCB and 99 percent of the PAH spike results. All spike results with poor recovery were above control limits. One spiked sample (set number 200503908) was ruined during preparation at the laboratory, and no results were reported. Surrogate recoveries were within acceptable ranges for 98 percent of the samples analyzed for OCs and PCBs, 93 percent of the samples analyzed for PAHs, and 96 percent of the blank and spiked samples. A problem was encountered during preparation of one $\mathrm{OC}$ and PCB sample (DSL.4 99-104) that required a 10-to-1 dilution, which subsequently raised the MRLs by a factor of 10 .

Quality assurance for analyses of major and trace elements was provided by analyzing four standard reference materials (SRMs) (appendix 3). Median RPD for all elements for all SRMs was 3.4 percent.

\section{Sources of Polychlorinated Biphenyls}

Undisturbed bed sediment cores from lakes and reservoirs can be used to reconstruct contaminant release histories in the watershed for persistent, hydrophobic compounds like PCBs if a sediment chronology can be established (Eisenreich and others, 1989; Van Metre and others, 1998). In reservoirs, one useful date marker is the boundary between lacustrine sediment and pre-reservoir material (Van Metre and others, 1997; Van Metre and others, 2004). That interface usually is characterized by an abrupt change from soft, fine-grained, highporosity sediment typical of lake-bottom environments to firmer, drier soil or sandy sediment. The nature of the prereservoir sediment varies depending on what existed at the location prior to the emplacement of the lake. Devils Swamp Lake was created by dredging, so it is expected that material underlying the lacustrine sediment is an alluvial clay or a deeper soil horizon and that it is much firmer and of lower porosity than the overlying lacustrine sediment.

Six cores were collected using a push corer. Each time, the push corer initially encountered little resistance as it penetrated the lacustrine sediment, then encountered firm resistance, relatively suddenly, at depth. Maximum recovery was $148 \mathrm{~cm}$ at DSL.2. No obvious pre-reservoir material was recovered in the cores, with the possible exception of a 1-cm layer of firm, silty clay at the bottom of DSL.5 (fig. 2). The initial ease of penetration and the relatively abrupt resistance to penetration at depth indicate the corer could easily penetrate soft lacustrine sediment but was stopped by pre-reservoir soil or clay. Deposition dates for samples from cores DSL.2, DSL.4, and DSL.5 were assigned assuming cores penetrated almost to the prereservoir soil marking 1973, when dredging formed the lake, and assuming a constant mass accumulation rate of sediment for each core. Mass accumulation rate in each core was calculated using measured porosity and an assumed density of solids (2.0 grams per cubic centimeter, typical of lake sediments with moderate organic carbon content [Van Metre and others, 2004]) for sediment samples over the time interval thought to be represented by the core. The time interval was from 1975 (the bottom of the core, assuming the bottom was just above the late-1973 


\section{Sources of Polychlorinated Biphenyls to Devils Swamp Lake Near Baton Rouge, Louisiana}

Table 1. Compound type, common name, abbreviation, and registry number for chlorinated hydrocarbon compounds.

[CAS, Chemical Abstracts Service; $\mu \mathrm{g} / \mathrm{kg}$, micrograms per kilogram --, none assigned]

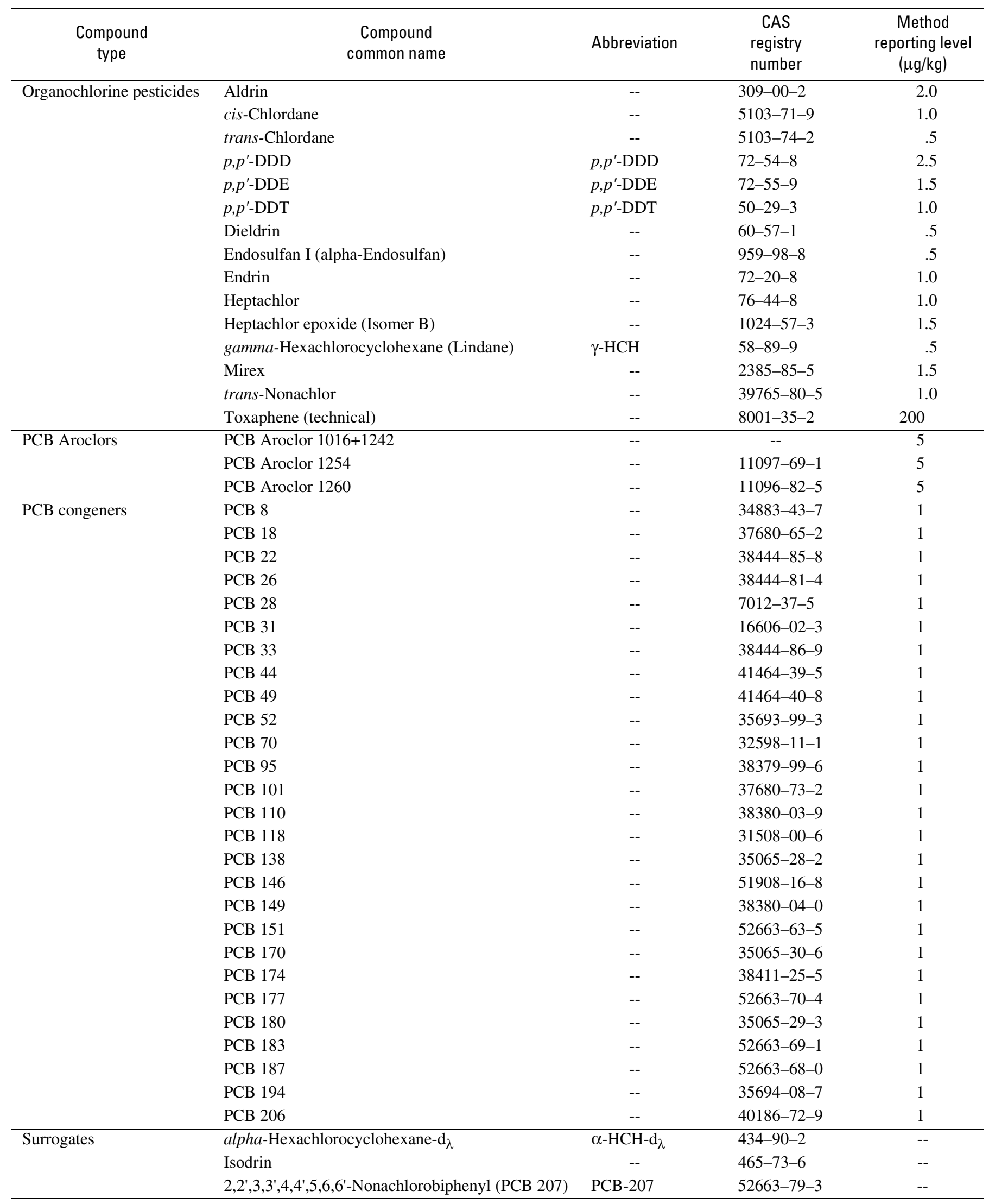


Core DSL.2

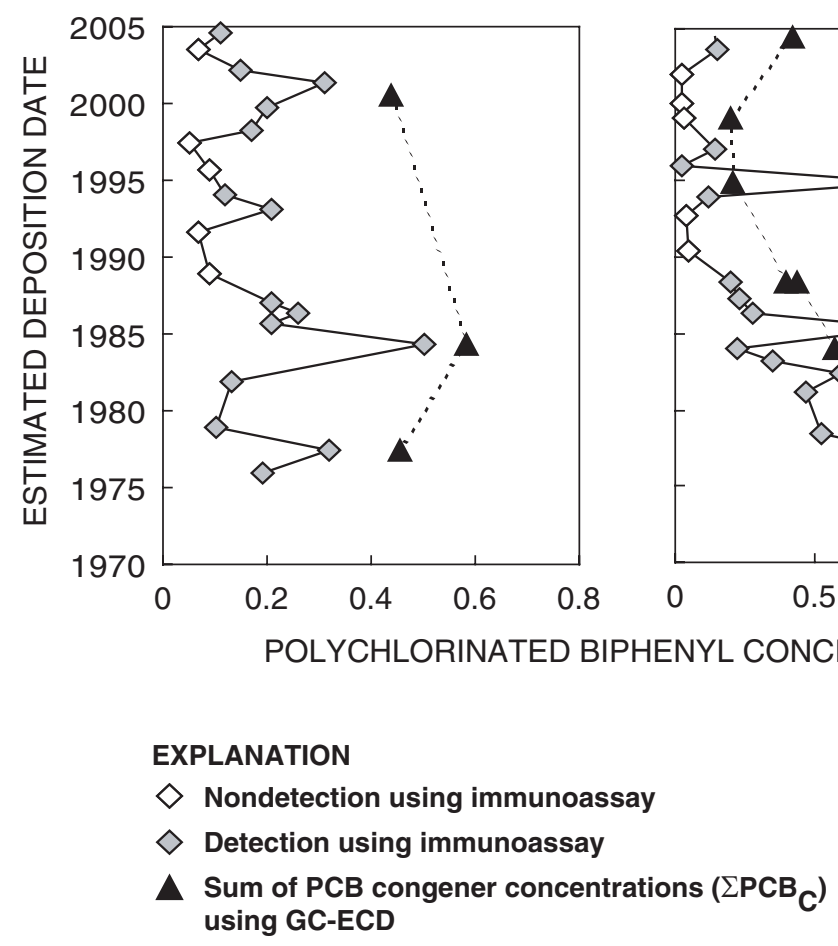

Core DSL.4

Core DSL.5

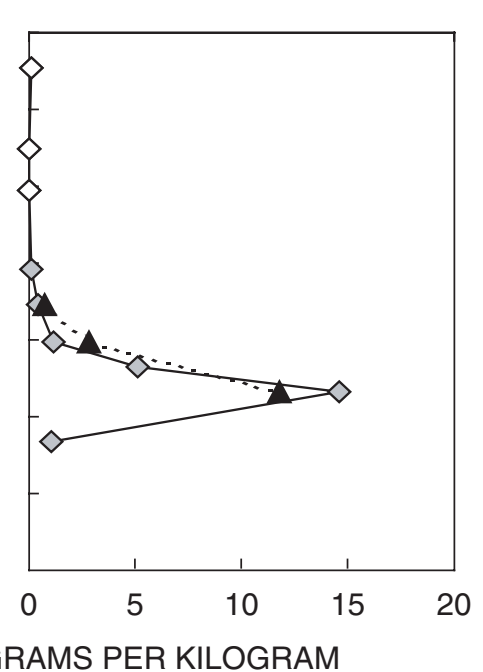

Figure 3. Concentrations of polychlorinated biphenyls (PCBs) in Devils Swamp Lake, Louisiana, cores-comparison of immunoassay screening results and laboratory analyses using gas chromatography with electron capture detection (GC-ECD).

completion of dredging) to the sampling date in October 2004 (the top of the core). This approach is similar to the approach used by Van Metre and others (2004) for reservoir cores where a single depth-date marker was known at depth in the core, usually either the construction date of the reservoir or the peak in radioactive cesium-137 activity.

All five cores from along the axis of the lake (excluding core DSL.6) had alternating light and dark layering, with dark layers more common in deeper sediments (Van Metre and Wilson, 2004). DSL.2, for example, was a relatively uniform olive gray to a depth of $75 \mathrm{~cm}$, then alternated between streaks of olive gray and black, some as thick as $2 \mathrm{~cm}$, to the bottom of the core at $148 \mathrm{~cm}$. Although the overall pattern of increasing numbers of dark sediment layers with increasing depth occurred in all five cores, there were differences between cores, and the dark layers could not be directly correlated between cores, even for cores collected close to one another.

\section{Concentrations and Trends}

PCBs were detected in about 70 percent of the 64 samples analyzed by immunoassay (excluding duplicates) (Van Metre and Wilson, 2004) and in all 16 samples analyzed in the laboratory (appendix 1). Immunoassay concentrations generally were lower than laboratory analyses of PCBs-the immunoassay results were 57 and 42 percent (median) of $\Sigma \mathrm{PCB}_{\mathrm{C}}$ and $\Sigma \mathrm{PCB}_{\mathrm{A}}$ concentrations, respectively-but reasonably represented the occurrence and patterns in trends (fig. 3). The highest concentrations were less than $58 \mathrm{~cm}$ (1985) in core DSL.5; the maximum $\Sigma \mathrm{PCB}_{\mathrm{C}}$ concentration was $12,000 \mu \mathrm{g} / \mathrm{kg}$ in sample DSL.5 69-73 (1982). $\Sigma \mathrm{PCB}_{\mathrm{A}}$ and the immunoassay concentrations were 20,000 and $14,500 \mu \mathrm{g} / \mathrm{kg}$ in this sample, respectively. The large, narrow peak in concentration and the nondetections using immunoassay in the upper part of the core indicate a short-term release for most of the PCBs and that the most contaminated bed sediment has since been buried by subsequent sediment deposition.

Concentrations of PCBs in cores DSL. 4 and DSL. 2 are about 10 to 20 times lower than the peak concentration in DSL.5 but are high compared with urban lake sediments in the United States and sediment-quality guidelines. The median $\Sigma \mathrm{PCB}_{\mathrm{A}}$ concentrations in the 1970s and 1990s in 14 densely urban lakes (greater than 50-percent urban land use in the watershed) in 10 major urban areas across the United States were 275 and 108 $\mu \mathrm{g} / \mathrm{kg}$, respectively (Van Metre and Mahler, 2005). The probable effect concentration (PEC) for PCBs is $676 \mu \mathrm{g} / \mathrm{kg}$ (MacDonald and others, 2000). The PEC is the concentration above which adverse effects on benthic biota in freshwater systems are expected. The PEC does not consider bioaccumulation in wildlife and its consequences, such as human health risk from ingestion of contaminated fish. Concentrations of $\Sigma \mathrm{PCB}_{\mathrm{A}}$ in DSL.4 


\section{Sources of Polychlorinated Biphenyls to Devils Swamp Lake Near Baton Rouge, Louisiana}

range from 350 to $2,000 \mu \mathrm{g} / \mathrm{kg}$ and in DSL.2 range from 610 to $910 \mu \mathrm{g} / \mathrm{kg}$ (appendix 1). Temporal trends in these two cores are not as pronounced as in core DSL.5, although the decrease in $\Sigma \mathrm{PCB}_{\mathrm{C}}$ over time in DSL.4 is statistically significant (using Kendall's tau: tau $=-.79$, $\mathrm{p}$-value $=.003$ ).

Samples were collected from two sites to provide possible source characterization. Site DSL.6 is about 50 meters north of DSL.5 at the mouth of Bayou Baton Rouge, the main inflow to the lake (fig. 1). The drainage area of that inflow contains industrial land uses on the north side of Baton Rouge. Immunoassay results from DSL.6 indicated moderately high PCB concentrations (less than 90 to $960 \mu \mathrm{g} / \mathrm{kg}$ ) and possibly a decrease over time (Van Metre and Wilson, 2004). The sample from DSL.6 with the highest immunoassay concentration (DSL.6 45-51) was analyzed at the laboratory and had a $\Sigma \mathrm{PCB}_{\mathrm{C}}$ of $1,400 \mu \mathrm{g} / \mathrm{kg}$ (appendix 1). The other area sampled for source characterization is the wastewater drainage ditch. PCBs were detected using immunoassay in the three bottom-material samples from the ditch at 1,800 (DSL.A), 2,200 (DSL.B), and 1,200 (DSL.C) $\mu \mathrm{g} / \mathrm{kg}$ for sites progressively toward the head of the ditch. Sample DSL.C was analyzed in the laboratory and had a $\Sigma \mathrm{PCB}_{\mathrm{C}}$ concentration of $970 \mu \mathrm{g} / \mathrm{kg}$. This sample was chosen because it was unlikely to have been influenced by any source other than the hazardous-chemical disposal facility.

\section{Polychlorinated Biphenyl Congener Patterns}

Patterns of PCB congener distributions in samples of sediment, water, and tissue have been used to evaluate sources of PCBs (Besse and others, 2005; Johnson and others, 2000; Meharg and others, 2003; Monosson and others, 2003) and PCB transformations in the environment (Karcher and others, 2004). To facilitate comparison of samples with different total PCB concentrations, each congener concentration was divided by the $\Sigma \mathrm{PCB}_{\mathrm{C}}$ concentration of the sample, yielding proportional values. Plots (profiles) of these patterns were overlaid to assess which samples were most like each other and which were different (fig. 4). The congener profile of DSL.C is shown on the first five plots (4A-E) as a bold black line. Profiles of DSL.4 and DSL. 2 show similarities to that of DSL.C but with large peaks in a few less-chlorinated congeners in some samples (fig. 4A, B). The samples with those large peaks are all from the deep parts of the cores; samples from the shallow parts of these cores (deposited after the mid-1980s) are very similar to the ditch sample in their PCB congener profiles (fig. 4C). The next deep sample in both cores was dated as 1984. The deep samples have PCB signatures that are different from that of DSL.C but similar to each other (fig. 4D). This indicates either a change in the nature of PCB discharges from the ditch in the mid-1980s (for example, a shift in the dominant Aroclor mixture being processed at the facility and discharged through the ditch) or input of PCBs from some other source. Not surprisingly, there is a shift in the relative proportions of Aroclors as well as congeners in these cores (fig. 5). Aroclor 1016+1242 is less chlorinated than Aroclor 1254 or 1260 and accounts for a higher proportion of PCBs in the deep samples. Since the mid-1980s the Aroclor and congener fractions are quite stable, with Aroclor 1254 dominating, similar to that of sample DSL.C.

PCB congener profiles from all four of the samples from DSL.5 and DSL. 6 are different from that of DSL.C, with the greatest difference in DSL.5 69-73 (fig. 4E), the sample with the highest concentration measured $\left(12,000 \mu \mathrm{g} / \mathrm{kg} \Sigma \mathrm{PCB}_{\mathrm{C}}\right)$. Relatively high concentrations also were measured in shallow intervals in DSL.5 (dated as 1985 and 1987) and in the sample from DSL.6 (45-51 cm down core) (appendix 1). The much higher concentration in DSL.5 69-73 than in samples closer to and in the ditch (DSL.2, DSL.4 and DSL.C) and the very different congener profile indicate that the large peak in PCBs in DSL.5 is not from the ditch. The proximity of the site to the mouth of Bayou Baton Rouge indicates the source is in that watershed; but if so, the source(s) in Bayou Baton Rouge appears to have changed over time because DSL.5 69-73 and DSL.6 45-51 have different congener patterns (fig. 4E). The congener patterns in the two shallower samples from core DSL.5 are similar in many respects to those in sample DSL.6, but different from those in DSL.5 69-73 and DSL.C. With only one sample from DSL.6 analyzed and no deposition dating information for the core, it is possible that the sample (DSL.6 45-51) was deposited after sample DSL.5 69-73 was deposited. The DSL.6 site is in shallow water (1.0 meters), and the core had zones with sand and root hairs, which indicate periodic exposure during low-water periods and possibly periodic erosion. No attempt was made to assign dates to samples from core DSL.6 because of uncertainty as to how stable deposited sediment was at the site over time. The Bayou Baton Rouge source responsible for the PCB peak at site DSL.5 also could have affected sediments nearer to the ditch. The congener patterns in the deep samples from cores DSL. 2 and DSL. 4 are similar to the pattern in sample DSL.5 69-73 (fig. 4F), and all of these samples were dated as deposited in the late 1970s and early 1980s.

\section{Multivariate Analysis of Polychlorinated Biphenyls}

Multivariate statistical techniques are available that can facilitate the comparison of congener patterns among samples. The technique used here is extended Q-mode (EQ-mode) factor analysis (Miesch, 1976), which was chosen because it is designed to work with compositional (proportional) data. As with all factor analytical techniques, the EQ-mode method is used to detect underlying structure in a multivariate dataset. A Q-mode analysis evaluates similarities between objects (samples) to discern patterns or groups that provide both classification of samples and explanation of provenance or sample origin (Davis, 1986). Each congener concentration was divided by the $\Sigma \mathrm{PCB}_{\mathrm{C}}$ concentration for the sample to convert concentrations to proportions of the total. When analyzing proportional data using factor analysis, a complication arises in that each row of data sums to a constant value ( 1 in this case), causing what it known as "closure" or the forced correlation among variables. 
A. Site DSL.4, all samples

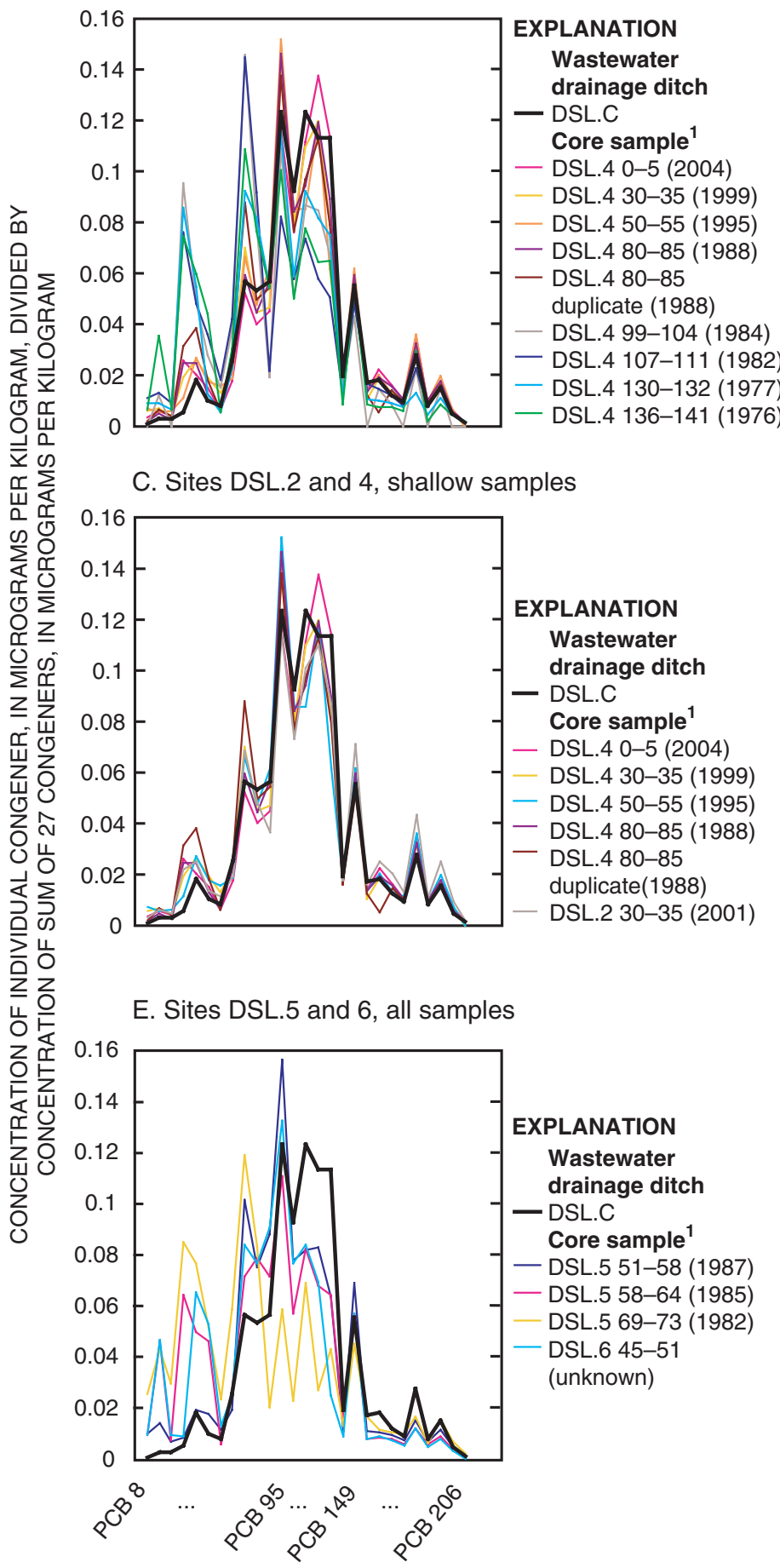

27 PCB CONGENERS
B. Site DSL.2, all samples

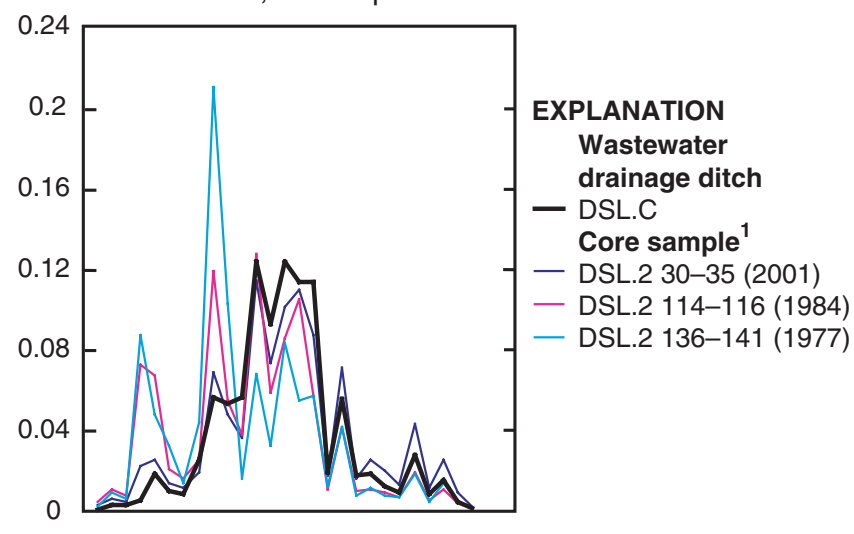

D. Sites DSL.2 and 4, deep samples

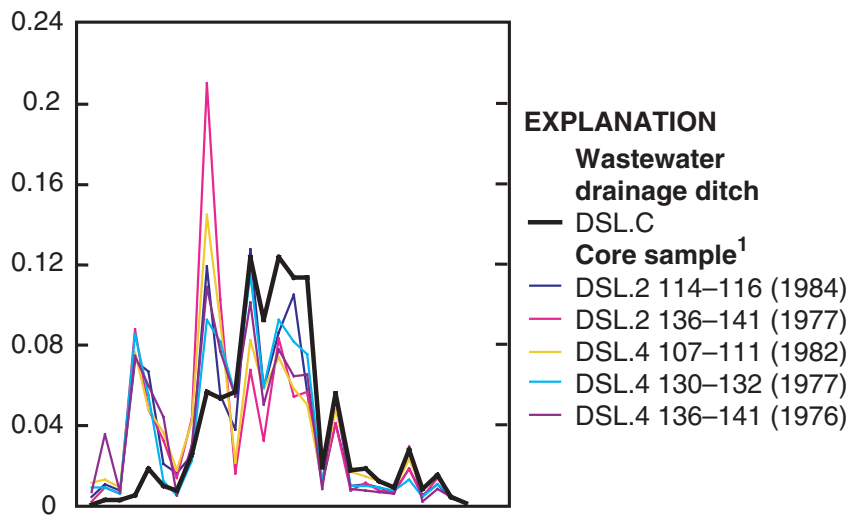

F. Sites DSL.5 69-73 and DSL.2 and DSL.4, deep samples

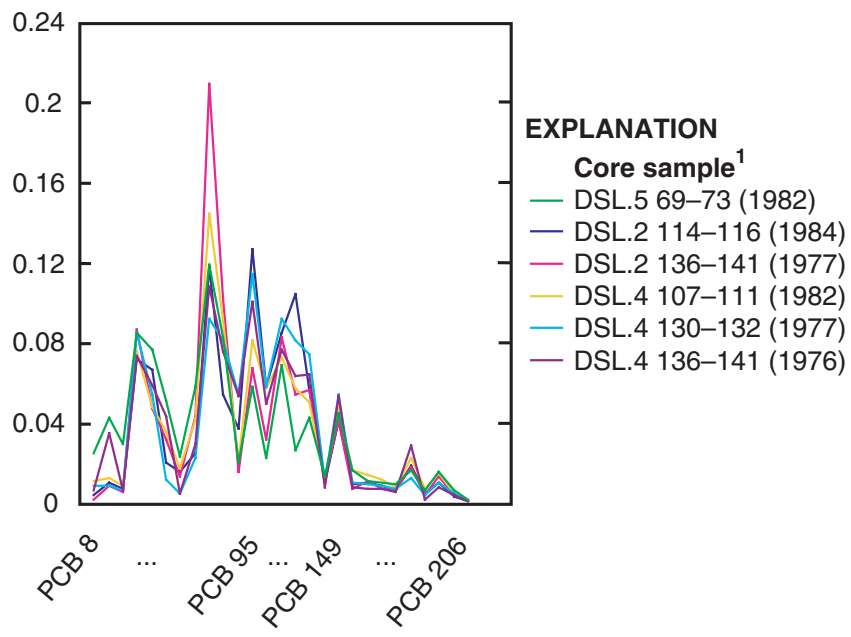

27 PCB CONGENERS

\footnotetext{
${ }^{1}$ Range in sample identifier indicates sample depth (centimeters) down core. Estimated sediment deposition date of samples follows in parenthesis.
}

Figure 4. Polychlorinated biphenyl (PCB) congener patterns in various groups of bed sediment samples collected in and near Devils Swamp Lake, Louisiana. 


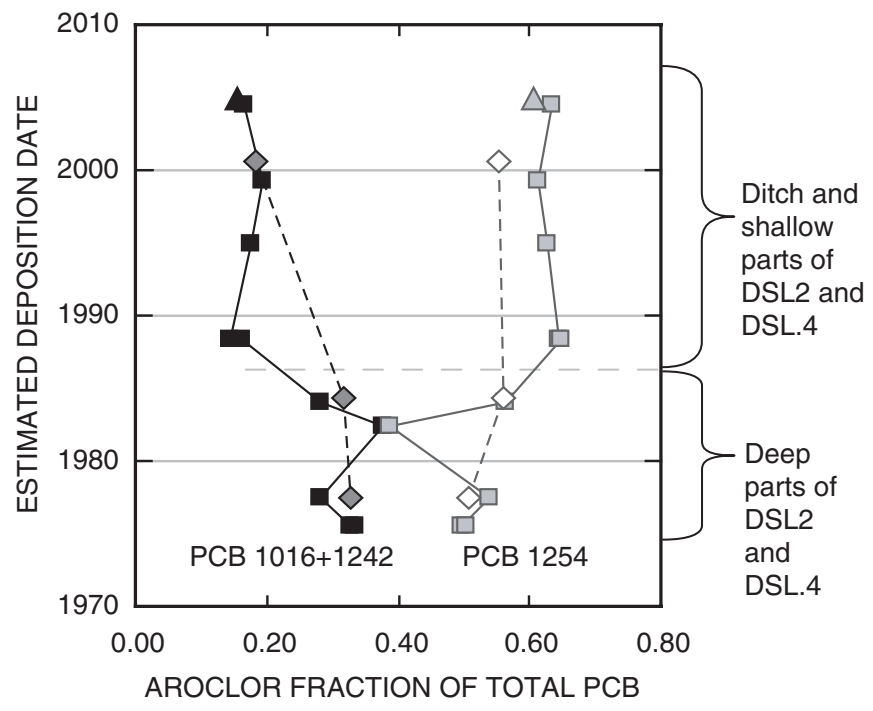

EXPLANATION

PCB 1016+1242, by site

- Core DSL.4

$\diamond$ Core DSL.2

$\triangle$ Ditch DSL.C

PCB 1254, by site

$\square$ Core DSL.4

$\diamond$ Core DSL.2

$\triangle$ Ditch DSL.C

Figure 5. Temporal shifts in relative concentrations (to total) of polychlorinated biphenyl (PCB) Aroclors in Devils Swamp Lake, Louisiana, bed sediments.

The special routines of EQ-mode analysis were developed to handle such data (Miesch, 1976).

Results of EQ-mode factor analysis are expressed as compositional loadings for each sample. These loadings represent the proportion of each end-member in a given sample. On the basis of eigenvalues and the evaluation of plots of congener profiles (fig. 4), three end-members adequately accounted for the variance in PCB congener composition among the samples. Three factors were determined using EQ-mode analysis and varimax normalized rotation, an orthogonal rotation technique that maximizes the variance of the elements in the columns of a factor matrix. These three factors accounted for 81.3 percent of the variance in the data. Scores that represent an idealized composition of the end-members in terms of the congeners and compositional loadings for samples are listed in tables 2 and 3 , respectively. Because the loadings are compositional, they sum to 1 for each sample.

Plotting compositional loadings on a tri-linear graph indicates which samples are most similar to the end-members, which samples should represent distinct sources, and which samples are most affected by those sources (fig. 6). DSL.C is most similar to end-member 1, indicating that this end-member represents sediment influenced by the wastewater drainage ditch source. Samples DSL.5 69-73 and DSL.6 45-51 are most similar to end-members 2 and 3, respectively, indicating two other PCB sources. The locations of cores DSL.5 and DSL.6 near the mouth of Bayou Baton Rouge and the different compositional loadings from samples near the wastewater drainage ditch, including DSL.C, indicate Bayou Baton Rouge as the source of end-members 2 and 3 . As noted above, the deposition date of DSL.6 45-51 is unknown, and it is possible that this sample and DSL.5 69-73 represent Bayou Baton Rouge sources active during different time periods.

Table 2. Scores for factors representing three end-members determined using EQ-mode factor analysis of polychlorinated biphenyl (PCB) congener concentrations in bed sediment from Devils Swamp Lake, Louisiana.

\begin{tabular}{|c|c|c|c|}
\hline Congener & Factor 1 & Factor 2 & Factor 3 \\
\hline PCB 8 & -0.01214 & 0.01647 & 0.01866 \\
\hline PCB 18 & -.05722 & .01661 & .11603 \\
\hline PCB 22 & -.01230 & .02203 & .01145 \\
\hline PCB 26 & -.07536 & .23367 & -.06497 \\
\hline PCB 28 & -.05172 & .10364 & .07816 \\
\hline PCB 31 & -.04802 & .05029 & .09132 \\
\hline PCB 33 & .00249 & .02630 & .00095 \\
\hline PCB 44 & -.00900 & .08080 & .00008 \\
\hline РСB 49 & -.03516 & .30550 & -.03231 \\
\hline PCB 52 & -.02393 & .13889 & .08125 \\
\hline PCB 70 & .05620 & -.07520 & .22721 \\
\hline РCB 95 & .20932 & -.02979 & .21394 \\
\hline PCB 101 & .14710 & -.03802 & .10949 \\
\hline PCB 110 & .15435 & .04733 & .06731 \\
\hline PCB 118 & .24214 & -.01771 & .04430 \\
\hline PCB 138 & .17339 & .02943 & -.01036 \\
\hline PCB 146 & .02834 & .00916 & .00157 \\
\hline PCB 149 & .07897 & .01149 & .08513 \\
\hline PCB 151 & .02158 & .01368 & -.00277 \\
\hline PCB 170 & .03775 & .00743 & -.00922 \\
\hline PCB 174 & .02784 & .00450 & -.00101 \\
\hline PCB 177 & .01833 & .00688 & -.00186 \\
\hline PCB 180 & .06412 & .01226 & -.01231 \\
\hline PCB 183 & .01838 & .00222 & -.00060 \\
\hline PCB 187 & .03238 & .01425 & -.00990 \\
\hline PCB 194 & .01010 & .00504 & -.00034 \\
\hline PCB 206 & .00209 & .00285 & -.00118 \\
\hline
\end{tabular}




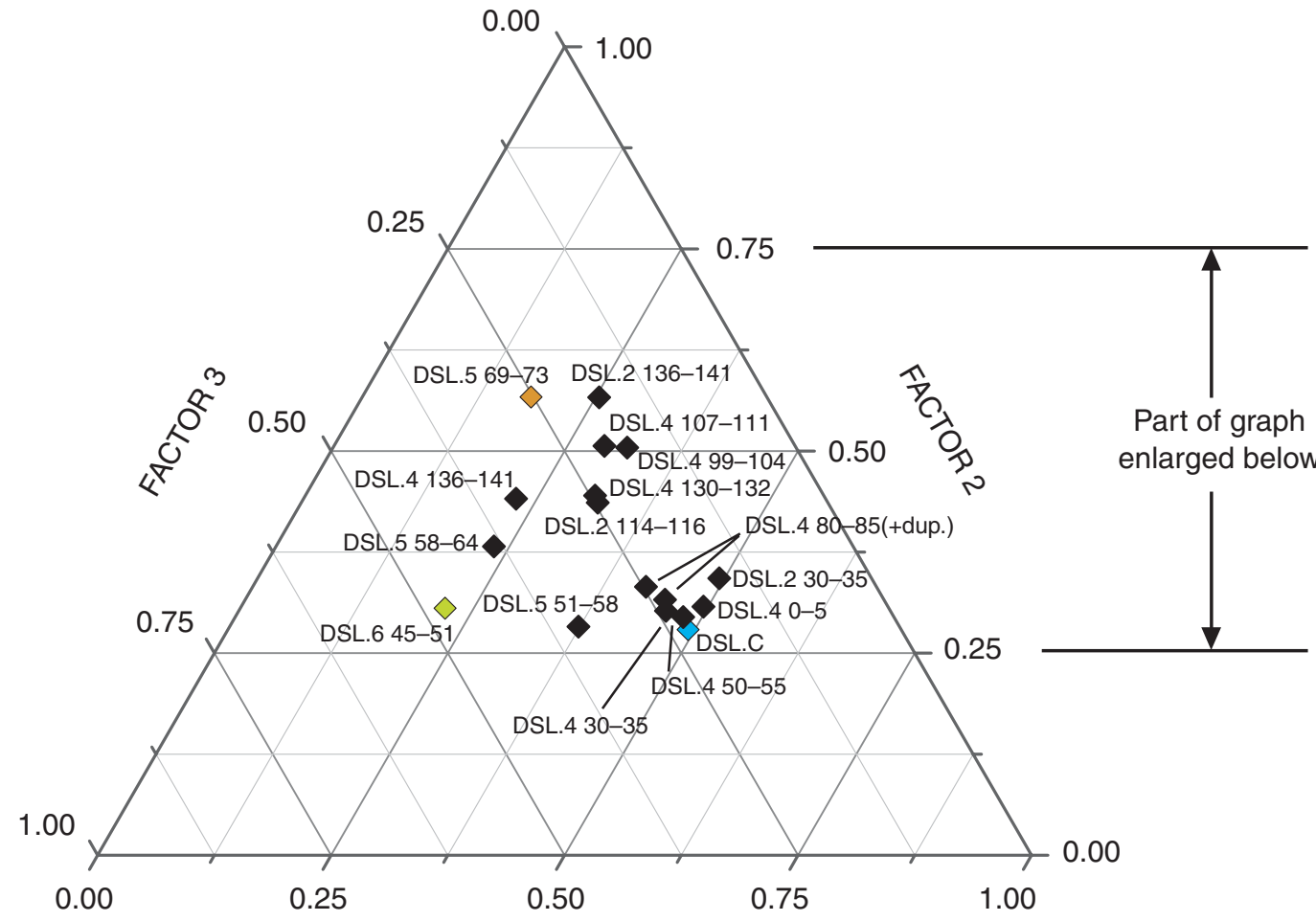

FACTOR 1

\section{Hypothetical mixing}

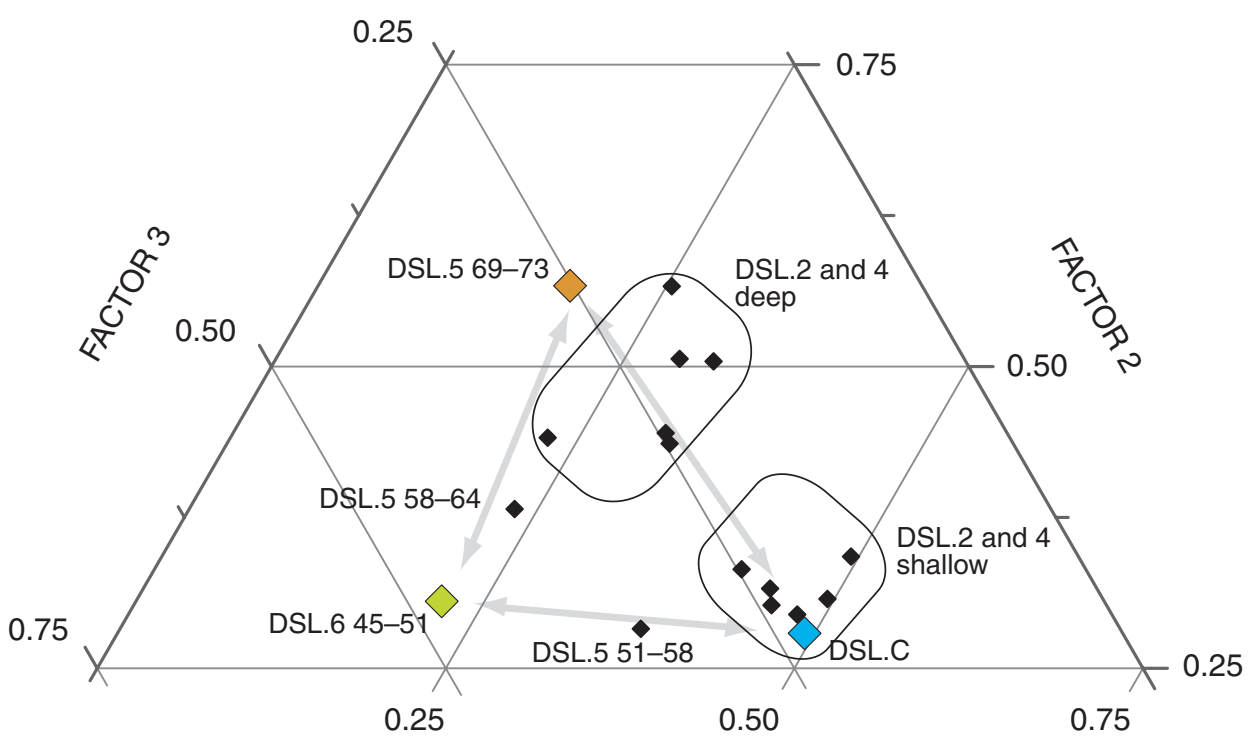

FACTOR 1

Figure 6. Factor loadings determined using proportions of polychlorinated biphenyl (PCB) congeners in samples from Devils Swamp Lake, Louisiana. Plotting positions of points on the two graphs are the same. 
Table 3. Compositional loadings of three end-members based on EQ-mode factor analysis for bed sediment samples from Devils Swamp Lake, Louisiana.

[lab. dup., laboratory duplicate]

\begin{tabular}{|c|c|c|c|}
\hline $\begin{array}{c}\text { Sample ID and interval } \\
\text { (centimeters), where } \\
\text { applicable }\end{array}$ & Factor 1 & Factor 2 & Factor 3 \\
\hline DSL.2 30-35 & 0.494 & 0.343 & 0.163 \\
\hline DSL.2 114-116 & .310 & .445 & .245 \\
\hline DSL.2 136-141 & .254 & .566 & .180 \\
\hline DSL.C & .493 & .279 & .228 \\
\hline DSL.4 0-5 & .495 & .308 & .198 \\
\hline DSL.4 30-35 & .450 & .316 & .235 \\
\hline DSL.4 50-55 & .458 & .302 & .240 \\
\hline DSL.4 80-85 & .480 & .295 & .226 \\
\hline DSL.4 80-85 lab. dup. & .421 & .332 & .247 \\
\hline DSL.4 99-104 & .315 & .504 & .181 \\
\hline DSL.4 107-111 & .290 & .506 & .204 \\
\hline DSL.4 130-132 & .317 & .436 & .247 \\
\hline DSL.4 136-141 & .228 & .441 & .331 \\
\hline DSL. 5 51-58 & .374 & .283 & .344 \\
\hline DSL.5 58-64 & .233 & .382 & .385 \\
\hline DSL.5 69-73 & .181 & .567 & .253 \\
\hline DSL.6 45-51 & .219 & .306 & .475 \\
\hline
\end{tabular}

PCBs in all of the other samples are mixtures of the three end-members (fig. 6). Samples that are most similar to DSL.C and are strongly affected by the drainage ditch (end-member 1) include all of the shallow (post mid-1980s) samples from DSL.2 and DSL.4. Samples from the deeper parts of cores DSL.2 and DSL.4 plot between DSL.5 69-73 and DSL.C, indicating a mixture of the ditch and Bayou Baton Rouge sources. Only two samples plot relatively closer to DSL.6 45-51, and both are from DSL.5 up-core from sample DSL.5 69-73 (more recently deposited).

The hypothesis that DSL.5 and DSL.6 are affected by Bayou Baton Rouge sources and that there was a temporal shift in those sources is supported by the factor analysis. Sample DSL.5 58-64, deposited about 2 years after DSL.5 69-73, is a mixture of end-members 2 and 3. Sample DSL.5 51-58, deposited about 2 years after DSL.5 58-64 (1987), is a mixture of end-members 3 (DSL.6) and 1 (DSL.C). This shift in the mixture of sources in the shallower (more recent) samples from DSL.5 is consistent with a temporal shift and decrease in importance in sources from Bayou Baton Rouge. Bayou Baton Rouge appears to have been a large source of PCBs to Devils Swamp Lake only during the early 1980s. The PCB concentration in sample DSL.5 77-83 (deposited about 1978) was $1,000 \mu \mathrm{g} / \mathrm{kg}$ by immunoassay, one-twentieth the concentration in DSL.5 69-73. PCB concentrations were low or not detected ( $150 \mu \mathrm{g} / \mathrm{kg}$ or less by immunoassay) in the four samples from core DSL.5 deposited after about 1988 and low or not detected (330 $\mu \mathrm{g} / \mathrm{kg}$ or less) in the three samples deposited after sample DSL.6 45-51 in core DSL.6 (fig. 3) (Van Metre and Wilson, 2004).

\section{Metals and Polycyclic Aromatic Hydrocarbons as Source Indicators}

Corroboration of different PCB sources to the middle-lake (DSL.5 and DSL.6) and upper-lake (DSL.2 and DSL.4) coring sites is provided by analyses of other anthropogenic contaminants in the cores. There are large differences in concentrations of antimony, cadmium, mercury, zinc, and PAHs among cores (fig. 7). Concentrations of four of five constituents (excluding cadmium) and the PAH source ratio shown in figure 7 are very different in sample DSL.5 69-73 than constituent concentrations and the PAH source ratio in cores DSL.2 and DSL.4. Differences in PAHs are especially notable. Concentrations of $\Sigma \mathrm{PAH}_{\mathrm{SQG}}$ (the summation used for the consensus-based sediment-quality guideline [Ingersoll and others, 2000]) are 37 times greater on average in sample DSL.5 69-73 than in the upper-lake cores, and the PAH assemblage is different. Petrogenic sources of PAHs (fuels) are dominated by the lower molecular weight (2- and 3-ringed) PAHs and alkyl-PAHs, whereas pyrogenic sources (combustion products) are dominated by the higher molecular weight (4-ringed and greater) parent compounds. The ratio of 2- and 3-ringed PAH plus alkyl$\mathrm{PAH}$ to 4 - and 5-ringed parent PAH $(2+3 / \mathrm{comb})$ indicates the relative dominance of pyrogenic (ratios less than about 1) or petrogenic PAHs (Van Metre and others, 2000). The 2+3/comb ratio in sample DSL.5 69-73 indicates a strongly petrogenic source (value of 4.0), whereas the sources of PAHs to the upperlake cores are both pyrogenic and petrogenic $(1.1 \pm 0.55)$. Thus, the mixture of contaminants in sample DSL.5 69-73 is different from those of other sites in the lake, including all samples from nearer the wastewater drainage ditch, and different from those of shallower zones in the same core.

\section{Historical Data Regarding a Second Source}

Support for the hypothesis of two different sources of PCBs also can be found in the historical data. The most comprehensive historical sampling at Devils Swamp Lake was done in 1992 by PRC Environmental Management, Inc. (PRC), for the U.S. Environmental Protection Agency (PRC Environmental Management, Inc., 1993). PRC collected bed sediment grab samples from 15 sites in the part of Devils Swamp Lake that this study sampled and from two sites in the wastewater drainage ditch (fig. 8) and detected elevated concentrations of PCBs at many sites. The highest concentrations in the PRC samples were from sites at the mouth of Bayou Baton Rouge, and relatively high concentrations were detected in samples from sites 

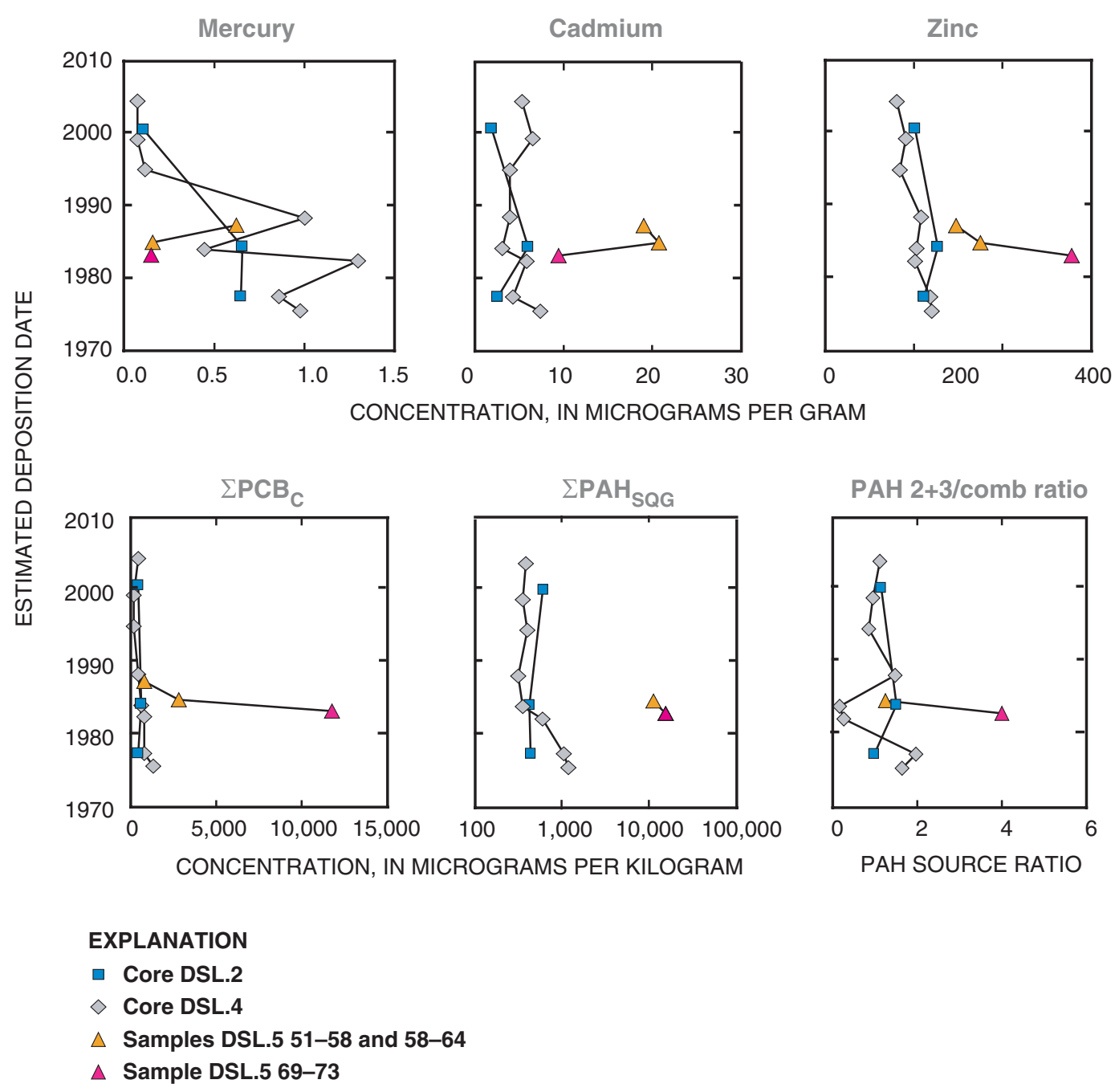

Note: The PAH source ratio is the sum of 2- and 3-ringed PAH plus alkyl-PAHs divided by the sum of 4- and 5-ringed parent PAH.

Figure 7. Temporal trends in concentrations of selected metals, the sum of polychlorinated biphenyl congeners $\left(\Sigma \mathrm{PCB}_{C}\right)$, the sum of selected polycyclic aromatic hydrocarbons $\left(\Sigma \mathrm{PAH}_{\mathrm{SQG}}\right.$ ), and the PAH source ratio (PAH 2+3/comb ratio) in cores DSL.2, DSL.4, and DSL.5, Devils Swamp Lake, Louisiana.

near the mouth of the drainage ditch and the far east end of the lake. Although there are differences in concentrations from the PRC study and this study, the general pattern of concentrations in samples from the USGS cores dated as deposited in the 1980s is similar to the pattern of PRC concentrations. It is unlikely that the PCBs in the samples near the mouth of Bayou Baton Rouge came from the drainage ditch because they are at higher concentrations than samples near the mouth of the ditch. Higher concentrations in bottom sediments farther from an inflow source can occur if, for example, the area closer to the inflow is a shallower or higher-energy environment, or both (resulting in primarily sandy sediments), and the area farther away is deeper and calmer, where fine-grained sediments accumulate. This, however, is not the case for the applicable part of Devils Swamp Lake. Water depth was 2.4 meters at sites DSL.2, DSL.4, and
DSL.5. Particle size was not analyzed in these samples, but aluminum, an element strongly associated with clays and sometimes used to normalize sediment samples for the effects of surface area, had similar concentrations in the cores (range from 59,400 to 87,600 micrograms per gram) (appendix 3).

PAHs also were measured by PRC, and the concentration distribution is consistent with that from this study and the conclusion of two sources of contamination to the lake. Much higher $\Sigma$ PAH ${ }_{\mathrm{SQG}}$ concentrations were detected by PRC in samples with high PCBs at the mouth of Bayou Baton Rouge than in samples from near the wastewater drainage ditch and from the far east end of the lake (fig. 8B). Viewing the PAHs as tracers of anthropogenic contamination, it appears that the contamination that entered Devils Swamp Lake from Bayou Baton 


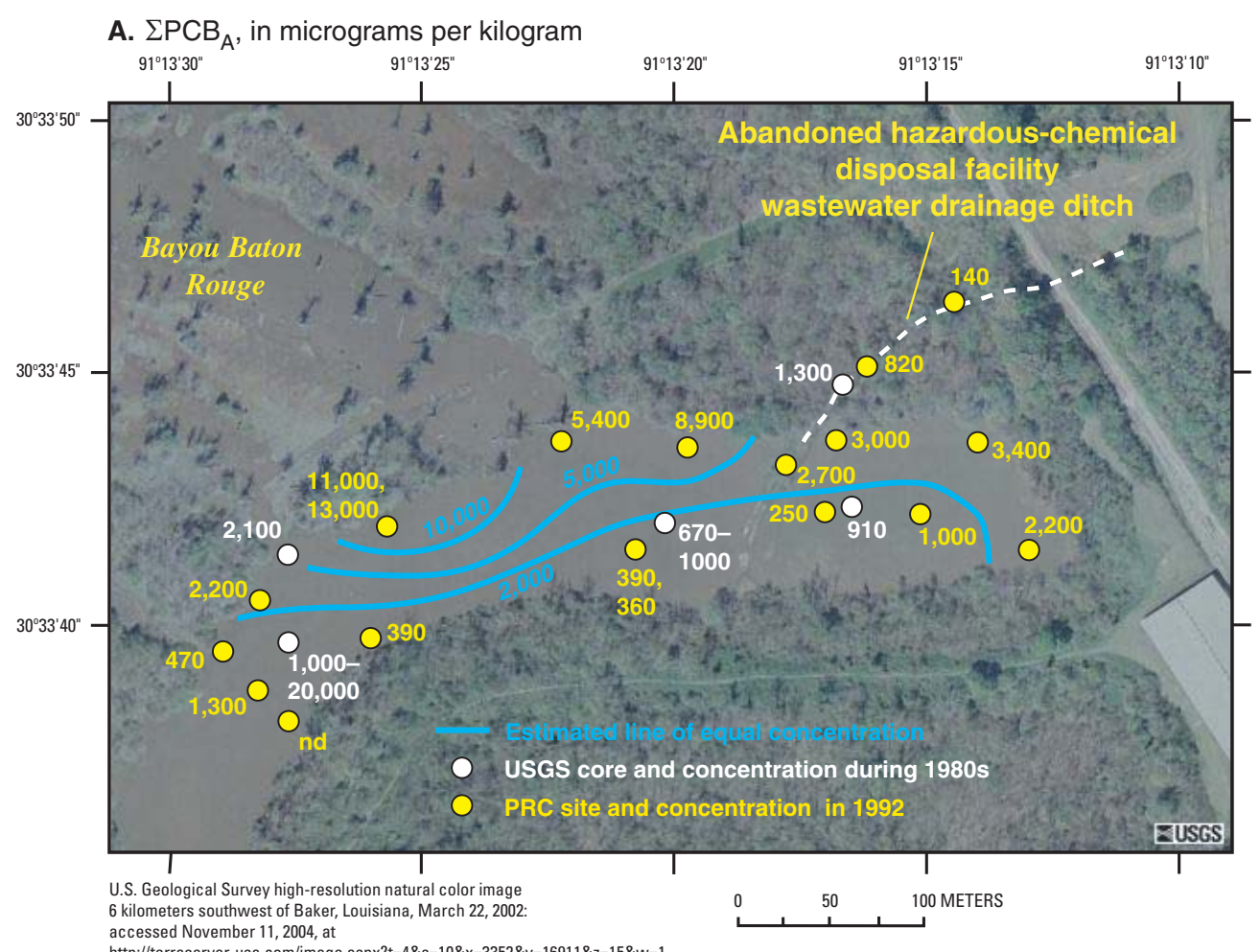

accessed November 11, 2004, at

B. $\Sigma \mathrm{PAH}_{\mathrm{SQG}}$, in micrograms per kilogram

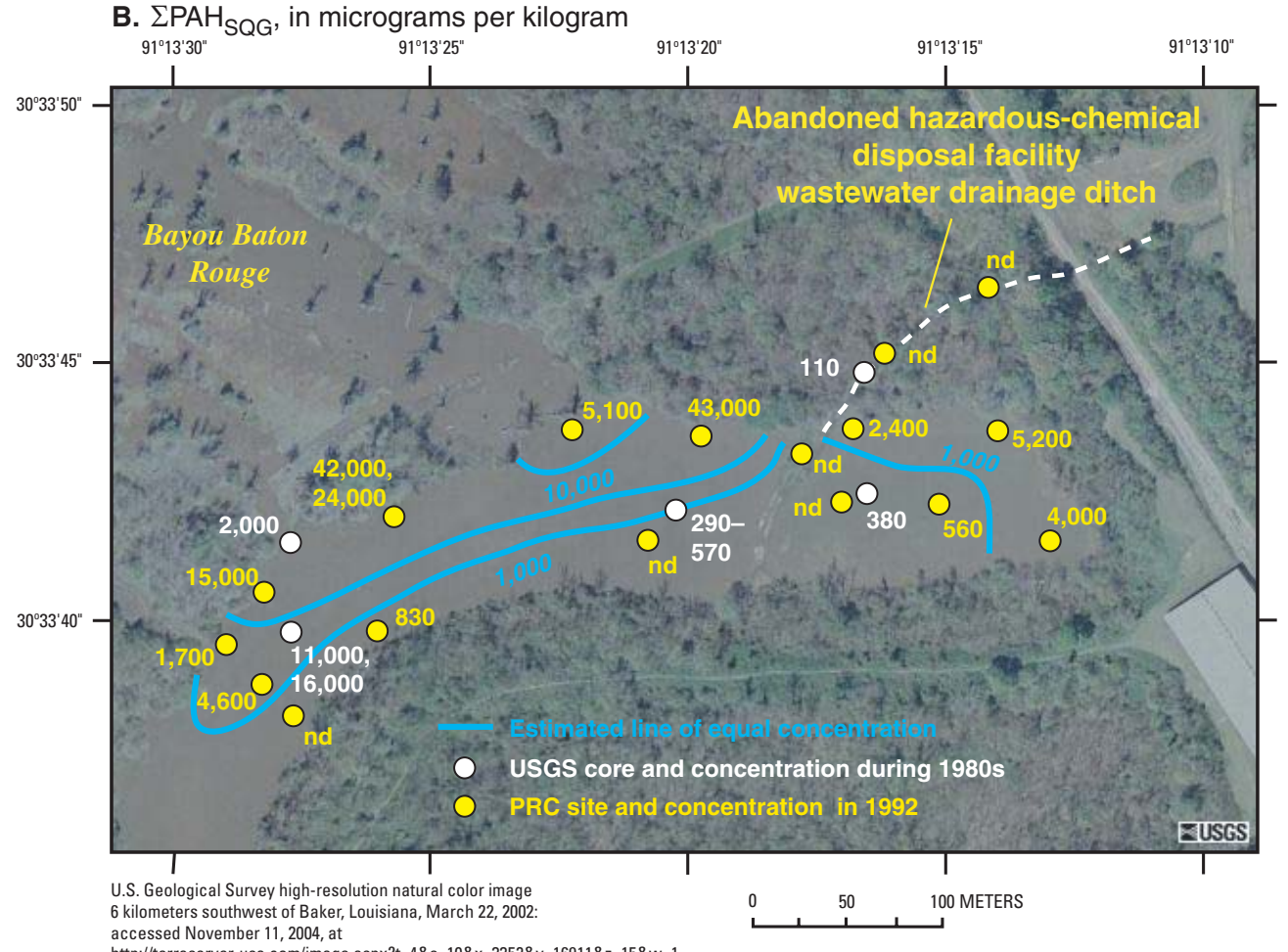

Figure 8. Aerial images of Devils Swamp Lake, Louisiana, showing concentrations of (A) the sum of polychlorinated biphenyl Aroclors $\left(\Sigma \mathrm{PCB}_{\mathrm{A}}\right)$ and $(\mathrm{B})$ the sum of 13 polycyclic aromatic hydrocarbon compounds used for the probable effects concentration $\left(\Sigma \mathrm{PAH} \mathrm{SOG}_{\mathrm{S}}\right.$ [Ingersoll and others, 2000]) in U.S. Geological Survey (USGS) core samples dated as mid-1980s and in grab samples collected in 1992 by PRC Environmental Management, Inc. (PRC Environmental Management, Inc., 1993). Lines of equal concentration on both maps are based on the PRC data. [nd = nondetection for all compounds in summations; nd for individual compounds treated as zero values in summations] 
Rouge had high concentrations of PCBs and PAHs, whereas the contamination that entered from the wastewater drainage ditch had high concentrations of PCBs but low concentrations of PAHs (fig. 8). A similar conclusion, higher concentrations from the Bayou Baton Rouge source, can be drawn for most metals. Metals with notably higher concentrations in cores DSL.5 and DSL.6 (and sample DSL.5 69-73) compared with those in cores DSL. 2 and DSL. 4 include antimony, arsenic, cadmium, chromium, lead, nickel, and zinc (appendix 3).

The duration of the PCB inputs varied as well, with a relatively short period of input from Bayou Baton Rouge and a much longer period of input from the drainage ditch. The short period of input from Bayou Baton Rouge is indicated by PCB concentration trends in core DSL.5 (fig. 3) and by the PCB congener profiles in deeper, older samples from DSL. 2 and DSL.4 that show inputs from the Bayou Baton Rouge source(s) only in intervals deposited in the late 1970s and early 1980s (fig. 4D). The long duration of PCB inputs from the drainage ditch is indicated by PCB concentrations and congener profiles in cores DSL.2 and DSL.4, which indicate a mixture of sources (Bayou Baton Rouge and the drainage ditch) in the late 1970s and early 1980s and primarily the drainage ditch source after the mid1980s. On the basis of the elevated PCB concentrations (greater than the median of $108 \mu \mathrm{g} / \mathrm{kg}$ from urban lakes and in many cases greater than the PEC of $676 \mu \mathrm{g} / \mathrm{kg}$ ) in recent (post-2000) drainage ditch sediment and in recently deposited sediments at DSL.2 and DSL.4, some PCB inputs from the ditch might still be occurring.

The identity of the Bayou Baton Rouge source(s) could not be established using available data. The short duration and relatively high concentration of PCBs from the bayou source (as indicated by PCB concentration trends in core DSL.5 and concentration in sample DSL.5 69-73) indicate either a spill or a flood-related release. There was a large flood on the Mississippi River in 1983, and a sediment plume was visible emanating from a natural drainage channel from the hazardous-chemical disposal facility in an aerial photograph taken in 1984 (U.S. Environmental Protection Agency, 2004b). The natural channel entered Bayou Baton Rouge upstream from Devils Swamp Lake and flowed through a "soil-borrow pit" at the disposal facility that was filled with "standing-liquid" pits. Other industrial and waste-processing facilities are in the watershed of Bayou Baton Rouge (Agency for Toxic Substances and Disease Registry, 1996). PCB congener data and other chemical data that might help identify sources, however, are not available from the other disposal facility channel(s), Bayou Baton Rouge, or other industrial sites in its watershed. If the source was the disposal facility by way of another channel, it must have come from a very different waste stream than material discharged by the wastewater drainage ditch sampled in this study. Alternatively, if the source was another facility farther upstream, a chemical record of those releases during the early 1980s might not be preserved in bottom sediments in Bayou Baron Rouge because of the dynamic nature of stream channels, where higher flows can remobilize and transport deposited sediments.

\section{Summary}

Devils Swamp Lake near Baton Rouge, La., created by dredging in 1973 in Devils Swamp along the Mississippi River, is contaminated with PCBs from historical industrial discharges. This report describes a study, done by the U.S. Geological Survey in cooperation with the U.S. Environmental Protection Agency, involved investigation of the occurrence and sources of PCBs in the lake, including the possible historical contribution of PCBs from a hazardous-chemical disposal facility by way of a wastewater drainage ditch that was used from 1971 to 1993. Six bed sediment cores from the lake and three bed sediment grab samples from the drainage ditch were collected; 61 subsamples from five of the six cores and the three grab samples from the ditch were analyzed for PCBs using an immunoassay screening method. Sixteen of the core subsamples and one ditch sample were analyzed for organochlorine pesticides, PCBs as Aroclor mixtures and as 27 specific congeners, PAHs (15 samples), and major and trace elements. The immunoassay screening method reasonably represented the overall patterns in concentrations in the laboratory analytical data.

The highest concentration of PCBs was in a sample deposited in about 1983 in core DSL.5, about 300 meters southwest of where the drainage ditch enters the lake and near the mouth of Bayou Baton Rouge. The PCB profile in this core defined a sharp peak in the early 1980s, with low concentrations after about 1990, indicating a short-term release in the early 1980s. Concentrations decreased much more slowly in core DSL. 4 and have remained variable but elevated over the past 25 years in core DSL.2, both of those sites about 50 meters west and east, respectively, from the low spit of land that marks the entrance of the ditch into the lake. PCBs were elevated in three samples of bed sediment from the ditch analyzed by immunoassay and confirmed in the one sample analyzed using GC-ECD at the laboratory.

PCB congener profiles and a factor analysis of congener composition indicate that PCBs in bed sediment from the drainage ditch and in lake bed sediment deposited near the ditch (cores DSL.2 and DSL.4) since the mid-1980s are similar, which indicate the hazardous-chemical disposal facility, by way of the wastewater drainage ditch, is the source of the PCBs. Bed sediment from several hundred meters to the west, near where Bayou Baton Rouge enters the lake (cores DSL.5 and DSL.6), had a different PCB composition, and in one sample deposited in the early 1980s, a much higher concentration, which indicates a second source of PCBs in the watershed of Bayou Baton Rouge. Large differences in PAHs and metals in cores from the two areas of the lake support the conclusion that there was a second PCB source. Older (deeper) samples from cores near the ditch (before the mid-1980s; cores DSL.2 and DSL.4) had PCB compositions indicating a mixture of the ditch source and the Bayou Baton Rouge source.

PCB profiles in the sediment cores indicate that the Bayou Baton Rouge source was large but of short duration, whereas 
the drainage ditch source appears to have introduced PCBs to the lake at relatively steady, elevated levels, since the lake was formed. The long duration of PCB releases from the drainage ditch source is indicated by PCB concentrations and congener profiles in cores DSL.2 and DSL.4, which reflect a mixture of sources (Bayou Baton Rouge and the drainage ditch) in the late 1970s and early 1980s and primarily the drainage ditch source after the mid-1980s. Elevated PCB concentrations (greater than the median of $108 \mu \mathrm{g} / \mathrm{kg}$ from urban lakes and in many cases above the PEC of $676 \mu \mathrm{g} / \mathrm{kg}$ ) in recent (pre-2000) drainage ditch sediment and in recently deposited sediment at DSL.2 and DSL.4 indicate that some PCB inputs from the ditch might still be occurring.

The identity of the Bayou Baton Rouge source(s) could not be established using available data. The short duration and relatively high concentrations of PCBs of the bayou source (as indicated by PCB concentration trends in core DSL.5 and concentration in sample DSL.5 69-73) indicate either a spill or a flood-related release- there was a large flood on the Mississippi River in 1983.

\section{Selected References}

Arbogast, B.F, ed., 1996, Analytical methods manual for the Mineral Resource Surveys Program: U.S. Geological Survey Open-File Report 96-525, 248 p.

Agency for Toxic Substances and Disease Registry, 1996, Public health assessment-Petro-Processors of Louisiana Incorporated, Baton Rouge, East Baton Rouge Parish, Louisiana: Agency for Toxic Substances and Disease Registry, accessed June 19, 2006, at http://www.atsdr.cdc.gov/ HAC/PHA/petro/pet_p1.html

Besse, R.E., Van Metre, P.C., and Wilson, J.T., 2005, Distribution and sources of polychlorinated biphenyls in Woods Inlet, Lake Worth, Fort Worth, Texas, 2003: U.S. Geological Survey Scientific Investigations Report 2005-5064, 46 p.

Briggs, P.H., and Meier, A.L., 2003, The determination of forty-two elements in geological materials by inductivelycoupled plasma-mass spectrometry for NAWQA, in Taggart, J.E.J., ed., Analytical methods for chemical analysis of geologic and other materials, U.S. Geological Survey: U.S. Geological Survey Open-File Report 2002-223, 16 p.

Davis, J.C., 1986, Statistics and data analysis in geology (2d ed.): New York, Wiley, 646 p.

Davis, R.B., 1980, The scope of Quaternary paleolimnology, in Davis, R.B., ed., Paleolimnology and the reconstruction of ancient environments: Boston, Kluwer Academic, p. 1-24.

Eisenreich, S.J., Capel, P.D., Robbins, J.A., and Boubonniere, R.A., 1989, Accumulation and diagenesis of chlorinated hydrocarbons in lacustrine sediments: Environmental Science and Technology, v. 23, no. 9, p. 1,116-1,126.

Ingersoll, C.G., MacDonald, D.D., Wang, N., Crane, J.L., Field, L.J., Haverland, P.S., Kemble, N.E., Lingskoog, R.A., Severn C., and Smorong, D.E., 2000, Prediction of sediment toxicity using consensus-based freshwater sediment quality guidelines: U.S. Environmental Protection Agency EPA 905/R-00/007, 25 p.

Johnson, G.W., Jarman, W.M., Bacon, C.E., Davis, J.A., Ehrlich, R., and Risenbough, R.W., 2000, Resolving polychlorinated biphenyl source fingerprints in suspended particulate matter of San Francisco Bay: Environmental Science and Technology, v. 34, no. 4, p. 552-559.

Karcher, S.C., Small, J.M., and Vanbriesen, J.M., 2004, Statistical method to evaluate the occurrence of PCB transformations in river sediments with application to Hudson River data: Environmental Science and Technology, v. 38, no. 24, p. 6,760-6,766.

MacDonald, D.D., Ingersoll, C.G., and Berger, T.A., 2000, Development and evaluation of consensus-based sediment quality guidelines for freshwater ecosystems: Archives of Environmental Contamination and Toxicology, v. 39, p. 20-31.

Meharg, A.A., Wright, J., Leeks, G.J.L., Wass, P.D., Owens, P.N., Walling, D.E., and Osborn, D., 2003, PCB congener dynamics in a heavily industrialized river catchment: The Science of the Total Environment, v. 314-316, p. 439-450.

Miesch, A.T., 1976, Interactive computer programs for petrologic modeling with extended Q-mode factor analysis: Computers and Geosciences, v. 2, p. 439-492.

Monosson, E., Ashley, J.T.F., McElroy, A.E., Woltering, D., and Elshus, A.A., 2003, PCB congener distributions in muscle, liver and gonad of Fundulus heteroclitus from the lower Hudson River Estuary and Newark Bay: Chemosphere, v. 52, p. 777-787.

Noriega, M.C., Wydoski, D.S., and Foreman, W.T., 2003, Methods of analysis by the U.S. Geological Survey National Water Quality Laboratory-Determination of organochlorine pesticides and polychlorinated biphenyls in bottom and suspended sediment by gas chromatography with electroncapture detection: U.S. Geological Survey Water-Resources Investigations Report 03-4293, 46 p.

Olson, M.C., Iverson, J.L., Furlong, E.T., and Schroeder, M.P., 2003, Methods of analysis by the U.S. Geological Survey National Water Quality Laboratory-Determination of polycyclic aromatic hydrocarbon compounds in sediment by gas chromatography/mass spectrometry: U.S. Geological Survey Water-Resources Investigations Report 03-4318, 45 p.

Potts, P.J., Tindle, A.G., and Webb, P.C., 1992, Geochemical reference material compositions-Rocks, minerals, sediments, soils, carbonates, refractories, and ores used in research and industry: Boca Raton, Fla., CRC Press, 313 p.

PRC Environmental Management, Inc., 1993, Expanded site inspection for Devil's Swamp Lake, East Baton Rouge Parish, Louisiana-Final report: U.S. Environmental Protection Agency LAD985202464.

Strategic Diagnostics, Inc., 2004, Remediation, assessment, \& industrial testing: RaPID Assay, [description], accessed October 2, 2006, at http://www.sdix.com/PDF/Products/ rapcbpp.pdf 
U.S. Environmental Protection Agency, 1997, The incidence and severity of sediment contamination in surface waters of the United States: Volume 1-National sediment quality survey: U.S. Environmental Protection Agency EPA 823-R-97-006.

U.S. Environmental Protection Agency, 2004a, Devil's Swamp Lake, Baton Rouge, Louisiana: U.S. Environmental Protection Agency, accessed June 19, 2006, at http://www.epa.gov/ earth1r6/6sf/pdffiles/devils_swamp.pdf

U.S. Environmental Protection Agency, 2004b, Aerial photographic analysis of Devil's Swamp Lake site, Scotlandville, Louisiana: U.S. Environmental Protection Agency Report no. TS-PIC-20506006S.

U.S. Environmental Protection Agency, 2006, Polychlorinated biphenyls (PCBs): U.S. Environmental Protection Agency, accessed June 19, 2006, at http://www.epa.gov/pcb/ index.html

Van Metre, P.C., Callender, Edward, and Fuller, C.C., 1997, Historical trends in organochlorine compounds in river basins identified using sediment cores from reservoirs: "Environmental Science and Technology, v. 31, no. 8, p. 2,339-2,344.
Van Metre, P.C., and Mahler, B.J., 2005, Trends in hydrophobic organic contaminants in lake sediments across the United States, 1970-2001: Environmental Science and Technology, v. 39 , no. 15 , p. $5,567-5,574$.

Van Metre, P.C., Mahler, B.J., and Furlong, E.T., 2000, Urban sprawl leaves its $\mathrm{PAH}$ signature: Environmental Science and Technology, v. 34, p. 4,064-4,070.

Van Metre, P.C., and Wilson, J.T., 2004, Immunoassay screening of sediment cores for polychlorinated biphenyls, Devils Swamp Lake near Baton Rouge, Louisiana, 2004: U.S. Geological Survey Open-File Report 2004-1397, 10 p.

Van Metre, P.C., Wilson, J.T., Callender, Edward, and Fuller, C.C., 1998, Similar rates of decrease of persistent, hydrophobic contaminants in riverine systems: Environmental Science and Technology, v. 32, no. 21, p. 3,312-3,317.

Van Metre, P.C., Wilson, J.T., Fuller, C.C., Callender, Edward, and Mahler, B.J., 2004, Collection, analysis, and age-dating of sediment cores from 56 U.S. lakes and reservoirs sampled by the U.S. Geological Survey, 1992-2001: U.S. Geological Survey Scientific Investigations Report 2004-5184, 180 p. 
Blank Page 


\section{Appendix 1-Analytical Results for Selected Chlorinated Hydrocarbon Compounds}


Blank Page 
Appendix 1. Analytical results for selected chlorinated hydrocarbon compounds from samples collected 0 ctober 5,2004 , from Devils Swamp Lake, Louisiana.

[In micrograms per kilogram except as indicated. Concentration in bold exceeds probable effect concentration (MacDonald and others, 2000). ID, identifier; $<$, nondetection at indicated value; E, estimated; --, not calculated; lab dup, laboratory duplicate; lab, laboratory; nr, not reported]

\begin{tabular}{|c|c|c|c|c|c|c|c|}
\hline $\begin{array}{c}\text { Sample ID and interval } \\
\text { (centimeters), where applicable }\end{array}$ & $\begin{array}{c}\text { Estimated } \\
\text { deposition } \\
\text { date }\end{array}$ & $\begin{array}{l}\text { Laboratory } \\
\text { set number }\end{array}$ & $\begin{array}{l}p, p^{\prime}- \\
D D D\end{array}$ & $\begin{array}{l}p, p^{\prime}- \\
\text { DDE }\end{array}$ & $\begin{array}{l}p, p^{\prime}- \\
\text { DDT }\end{array}$ & Dieldrin & $\begin{array}{l}\text { Heptachlor } \\
\text { epoxide }\end{array}$ \\
\hline DSL.2 114-116 & 1984 & 200503908 & $<5.0$ & E1.5 & $<2.0$ & $<1.0$ & $<2.0$ \\
\hline DSL.2 136-141 & 1977 & 200503908 & 1.3 & 1.7 & $<1.0$ & $<.5$ & $<1.0$ \\
\hline DSL.4 0-5 & 2004 & 200503908 & $<2.5$ & E1.0 & E1.0 & $<.5$ & $<1.0$ \\
\hline DSL.4 30-35 & 1999 & 200503908 & $<2.5$ & E.9 & E. 8 & $<.5$ & $<1.0$ \\
\hline DSL.4 50-55 & 1995 & 200503908 & $<2.5$ & E1.1 & $<1.0$ & $<.5$ & $<1.0$ \\
\hline DSL.4 99-104 & 1984 & 200503908 & $<25$ & $<15$ & $<10$ & $<5.0$ & $<10$ \\
\hline DSL.4 107-111 & 1982 & 200506805 & 2.9 & 5.8 & $<1.0$ & $<.5$ & $<1.0$ \\
\hline DSL.4 130-132 & 1977 & 200504607 & E1.4 & 2.9 & $<1.0$ & $<.5$ & $<1.0$ \\
\hline DSL.4 136-141 & 1976 & 200504607 & $<2.5$ & 4.2 & $<1.0$ & $<.5$ & $<1.0$ \\
\hline DSL.4 136--141 lab dup & 1976 & 200504607 & $<2.5$ & 3.8 & $<1.0$ & $<.5$ & E.9 \\
\hline DSL.5 51-58 & 1987 & 200504607 & E1.6 & 2.7 & $<1.0$ & $<.5$ & E.6 \\
\hline DSL.5 58-64 & 1985 & 200504607 & 5.6 & 10.5 & 6.9 & $<1.0$ & $<2.0$ \\
\hline DSL.5 69-73 & 1982 & 200504607 & 19 & 34 & 2.7 & 2.3 & $<1.0$ \\
\hline \multicolumn{8}{|l|}{ Quality assurance samples } \\
\hline Lab blank & -- & 200503908 & $<2.5$ & $<1.5$ & $<1$ & $<.5$ & $<1.5$ \\
\hline $\begin{array}{l}\text { Lab spike, in percent recovered } \\
\text { (acceptable range) }\end{array}$ & -- & 200503908 & $\mathrm{nr}$ & $\mathrm{nr}$ & $\mathrm{nr}$ & $\mathrm{nr}$ & $\mathrm{nr}$ \\
\hline Lab blank & -- & 200504607 & $\mathrm{nr}$ & $\mathrm{nr}$ & $\mathrm{nr}$ & $\mathrm{nr}$ & $\mathrm{nr}$ \\
\hline $\begin{array}{l}\text { Lab spike, in percent recovered } \\
\text { (acceptable range) }\end{array}$ & -- & 200504607 & $70(22-110)$ & $81(49-121)$ & $102(37-99)$ & $93(40-98)$ & $94(43-88)$ \\
\hline Lab blank & -- & 200506805 & $<2.5$ & $<1.5$ & $<1$ & $<.5$ & $<1.5$ \\
\hline $\begin{array}{l}\text { Lab spike, in percent recovered } \\
\text { (acceptable range) }\end{array}$ & -- & 200506805 & $84(22-110)$ & $75(49-121)$ & nr (37-99) & $64(40-98)$ & $57(43-88)$ \\
\hline
\end{tabular}




\section{Sources of Polychlorinated Biphenyls to Devils Swamp Lake Near Baton Rouge, Louisiana}

Appendix 1. Analytical results for selected chlorinated hydrocarbon compounds from samples collected October 5, 2004, from Devils Swamp Lake, Louisiana—Continued.

\begin{tabular}{|c|c|c|c|c|c|c|}
\hline $\begin{array}{c}\text { Sample ID and interval } \\
\text { (centimeters), where applicable }\end{array}$ & $\begin{array}{l}\text { Estimated } \\
\text { deposition } \\
\text { date }\end{array}$ & $\begin{array}{l}\text { Laboratory } \\
\text { set number }\end{array}$ & $\begin{array}{l}\text { Hexa- } \\
\text { chloro- } \\
\text { benzene }\end{array}$ & $\begin{array}{l}\text { PCB } \\
\text { Aroclor } \\
1254\end{array}$ & $\begin{array}{l}\text { PCB } \\
\text { Aroclor } \\
1260\end{array}$ & $\begin{array}{c}\text { PCB } \\
\text { Aroclor } \\
1016+1242\end{array}$ \\
\hline DSL. $230-35$ & 2001 & 200503908 & E2.2 & 420 & 200 & 140 \\
\hline DSL.2 114-116 & 1984 & 200503908 & E4.9 & 510 & 110 & 290 \\
\hline DSL.2 136-141 & 1977 & 200503908 & E1.5 & 310 & 100 & 200 \\
\hline DSL.C & -- & 200506805 & 1.9 & E780 & E310 & 200 \\
\hline DSL. $40-5$ & 2004 & 200503908 & $\mathrm{E} 2.2$ & 500 & 160 & 130 \\
\hline DSL.4 30-35 & 1999 & 200503908 & E2.4 & 220 & 69 & 70 \\
\hline DSL.4 50-55 & 1995 & 200503908 & E3.7 & 220 & 69 & 62 \\
\hline DSL.4 80-85 & 1988 & 200503908 & E2.9 & 430 & 140 & 96 \\
\hline DSL.4 80-85 lab dup & 1988 & 200503908 & E3.1 & 440 & 130 & 110 \\
\hline DSL.4 99-104 & 1984 & 200503908 & $<30$ & E440 & E120 & E220 \\
\hline DSL.4 107-111 & 1982 & 200506805 & 4.2 & 400 & 240 & 390 \\
\hline DSL.4 130-132 & 1977 & 200504607 & 4.1 & 628 & 207 & 327 \\
\hline DSL.4 136-141 & 1976 & 200504607 & 3.9 & 935 & 323 & 618 \\
\hline DSL.4 136-141 lab dup & 1976 & 200504607 & 5.0 & 1,030 & 333 & 683 \\
\hline DSL. 5 51-58 & 1987 & 200504607 & 4.9 & 561 & 181 & 318 \\
\hline DSL.5 58-64 & 1985 & 200504607 & E5.2 & 1790 & 628 & 552 \\
\hline DSL.5 69-73 & 1982 & 200504607 & 3.1 & $\mathrm{E} 5,760$ & 2,300 & E11,900 \\
\hline DSL.6 45-51 & -- & 200504607 & E1.9 & 1,110 & 246 & 754 \\
\hline \multicolumn{7}{|l|}{ Sediment-quality guidelines } \\
\hline $\begin{array}{l}\text { Threshold effect concentration } \\
\text { (TEC) }\end{array}$ & -- & none & -- & -- & -- & -- \\
\hline $\begin{array}{l}\text { Probable effect concentration } \\
\text { (PEC) }\end{array}$ & -- & none & -- & -- & -- & -- \\
\hline \multicolumn{7}{|l|}{ Quality assurance samples } \\
\hline Lab blank & -- & 200503908 & $<3$ & $<5$ & $<5$ & $<5$ \\
\hline $\begin{array}{l}\text { Lab spike, in percent recovered } \\
\text { (acceptable range) }\end{array}$ & -- & 200503908 & $\mathrm{nr}$ & $\mathrm{nr}$ & $\mathrm{nr}$ & $\mathrm{nr}$ \\
\hline Lab blank & -- & 200504607 & $\mathrm{nr}$ & $\mathrm{nr}$ & $\mathrm{nr}$ & $\mathrm{nr}$ \\
\hline $\begin{array}{l}\text { Lab spike, in percent recovered } \\
\text { (acceptable range) }\end{array}$ & -- & 200504607 & $67(29-83)$ & $102(43-131)$ & $93(50-122)$ & $90(29-109)$ \\
\hline Lab blank & -- & 200506805 & $<3$ & $<5$ & $<5$ & $<5$ \\
\hline $\begin{array}{l}\text { Lab spike, in percent recovered } \\
\text { (acceptable range) }\end{array}$ & -- & 200506805 & $65(29-83)$ & $99(43-131)$ & $87(50-122)$ & $84(29-109)$ \\
\hline
\end{tabular}


Appendix 1. Analytical results for selected chlorinated hydrocarbon compounds from samples collected 0 ctober 5, 2004, from Devils Swamp Lake, Louisiana—Continued.

\begin{tabular}{|c|c|c|c|c|c|c|c|}
\hline $\begin{array}{c}\text { Sample ID and interval } \\
\text { (centimeters), where applicable }\end{array}$ & $\begin{array}{c}\text { Estimated } \\
\text { deposition } \\
\text { date }\end{array}$ & $\begin{array}{l}\text { Laboratory } \\
\text { set number }\end{array}$ & $\begin{array}{l}\text { cis- } \\
\text { Chlordane }\end{array}$ & $\begin{array}{l}\text { trans- } \\
\text { Chlordane }\end{array}$ & $\begin{array}{l}\text { trans- } \\
\text { Nonachlor }\end{array}$ & $\begin{array}{l}\mathrm{PCB} \\
8\end{array}$ & $\begin{array}{l}\text { PCB } \\
18\end{array}$ \\
\hline DSL.2 30-35 & 2001 & 200503908 & $<1.0$ & $<0.5$ & $<1.0$ & 1.3 & 2.8 \\
\hline DSL.2 114-116 & 1984 & 200503908 & $<2.0$ & $<1.0$ & $<2.0$ & 2.9 & 6.5 \\
\hline DSL.2 136-141 & 1977 & 200503908 & $<1.0$ & 1.0 & $<1.0$ & 1.1 & 4.4 \\
\hline DSL.C & -- & 200506805 & E.6 & E.6 & $<1.0$ & E. 8 & 3.1 \\
\hline DSL.4 0-5 & 2004 & 200503908 & $<1.0$ & $<.5$ & $<1.0$ & 1.6 & 2.5 \\
\hline DSL.4 30-35 & 1999 & 200503908 & $<1.0$ & $<.5$ & $<1.0$ & 1.2 & 1.4 \\
\hline DSL.4 50-55 & 1995 & 200503908 & $<1.0$ & $<.5$ & $<1.0$ & 1.5 & 1.2 \\
\hline DSL.4 80-85 & 1988 & 200503908 & $<1.0$ & $<.5$ & $<1.0$ & E. 9 & 2.0 \\
\hline DSL.4 80-85 lab dup & 1988 & 200503908 & $<1.0$ & $<.5$ & $<1.0$ & 1.0 & 3.0 \\
\hline DSL.4 99-104 & 1984 & 200503908 & $<10$ & $<5.0$ & $<10$ & $<10$ & E6.9 \\
\hline DSL.4 107-111 & 1982 & 200506805 & $<1.0$ & $<.5$ & $<1.0$ & 9.4 & 11 \\
\hline DSL.4 130-132 & 1977 & 200504607 & $<1.0$ & E.7 & E.9 & 6.8 & 7.0 \\
\hline DSL.4 136-141 & 1976 & 200504607 & $<1.0$ & $<.5$ & $<1.0$ & 8.7 & 46 \\
\hline DSL.4 136-141 lab dup & 1976 & 200504607 & $<1.0$ & $<.8$ & $<1.0$ & $\mathrm{nr}$ & $\mathrm{nr}$ \\
\hline DSL.5 51-58 & 1987 & 200504607 & $<1.0$ & $<.5$ & $<1.0$ & 7.9 & 11 \\
\hline DSL.5 58-64 & 1985 & 200504607 & $<2.0$ & $<1.0$ & $<2.0$ & 28 & 130 \\
\hline DSL.5 69-73 & 1982 & 200504607 & 4.2 & 3.4 & $<1.0$ & 300 & 510 \\
\hline DSL.6 45-51 & -- & 200504607 & $<1.0$ & $<.50$ & $<1.0$ & 14 & 67 \\
\hline \multicolumn{8}{|l|}{ Sediment-quality guidelines } \\
\hline $\begin{array}{l}\text { Threshold effect concentration } \\
\text { (TEC) }\end{array}$ & -- & none & -- & -- & -- & -- & -- \\
\hline $\begin{array}{l}\text { Probable effect concentration } \\
\text { (PEC) }\end{array}$ & -- & none & -- & -- & -- & -- & -- \\
\hline \multicolumn{8}{|l|}{ Quality assurance samples } \\
\hline Lab blank & -- & 200503908 & $<1$ & $<.5$ & $<1$ & $\mathrm{nr}$ & $\mathrm{nr}$ \\
\hline $\begin{array}{l}\text { Lab spike, in percent recovered } \\
\text { (acceptable range) }\end{array}$ & -- & 200503908 & $\mathrm{nr}$ & $\mathrm{nr}$ & $\mathrm{nr}$ & $\mathrm{nr}$ & $\mathrm{nr}$ \\
\hline Lab blank & -- & 200504607 & $\mathrm{nr}$ & $\mathrm{nr}$ & $\mathrm{nr}$ & $\mathrm{nr}$ & $\mathrm{nr}$ \\
\hline $\begin{array}{l}\text { Lab spike, in percent recovered } \\
\text { (acceptable range) }\end{array}$ & -- & 200504607 & $102(43-87)$ & $103(48-84)$ & $102(46-90)$ & $\mathrm{nr}$ & $\mathrm{nr}$ \\
\hline Lab blank & -- & 200506805 & $<1$ & $<.5$ & $<1$ & $\mathrm{nr}$ & $\mathrm{nr}$ \\
\hline $\begin{array}{l}\text { Lab spike, in percent recovered } \\
\text { (acceptable range) }\end{array}$ & -- & 200506805 & $59(43-87)$ & $60(48-84)$ & $53(46-90)$ & $\mathrm{nr}$ & $\mathrm{nr}$ \\
\hline
\end{tabular}




\section{Sources of Polychlorinated Biphenyls to Devils Swamp Lake Near Baton Rouge, Louisiana}

Appendix 1. Analytical results for selected chlorinated hydrocarbon compounds from samples collected 0ctober 5, 2004, from Devils Swamp Lake, Louisiana-Continued.

\begin{tabular}{|c|c|c|c|c|c|c|c|c|}
\hline $\begin{array}{l}\text { Sample ID and interval } \\
\text { (centimeters), where applicable }\end{array}$ & $\begin{array}{c}\text { Estimated } \\
\text { deposition } \\
\text { date }\end{array}$ & $\begin{array}{l}\text { Laboratory } \\
\text { set number }\end{array}$ & $\begin{array}{l}\text { PCB } \\
22\end{array}$ & $\begin{array}{l}\text { PCB } \\
26\end{array}$ & $\begin{array}{c}\text { PCB } \\
28\end{array}$ & $\begin{array}{l}\text { PCB } \\
31\end{array}$ & $\begin{array}{l}\mathrm{PCB} \\
33\end{array}$ & $\begin{array}{l}\mathrm{PCB} \\
44\end{array}$ \\
\hline DSL.2 30-35 & 2001 & 200503908 & 2.1 & 9.7 & 11 & 5.9 & 5.0 & 8.5 \\
\hline DSL.2 114-116 & 1984 & 200503908 & 4.4 & 42 & 39 & 12 & 9.4 & 15 \\
\hline DSL.2 136-141 & 1977 & 200503908 & 3.0 & 40 & 22 & 15 & 6.3 & 20 \\
\hline DSL.C & -- & 200506805 & 3.2 & 5.6 & 18 & 10 & 7.9 & 25 \\
\hline DSL.4 0-5 & 2004 & 200503908 & 1.8 & 11 & 8.5 & 6.4 & 2.7 & 7.5 \\
\hline DSL.4 30-35 & 1999 & 200503908 & E. 8 & 3.9 & 5.3 & 3.9 & 2.6 & 4.4 \\
\hline DSL.4 50-55 & 1995 & 200503908 & 1.3 & 2.4 & 5.7 & 3.7 & 3.3 & 4.0 \\
\hline DSL.4 80-85 & 1988 & 200503908 & 1.1 & 10 & 10 & 5.2 & 2.6 & 9.3 \\
\hline DSL.4 80-85 lab dup & 1988 & 200503908 & 1.9 & 14 & 17 & 8.2 & 2.7 & 12 \\
\hline DSL.4 99-104 & 1984 & 200503908 & $<10$ & E55 & E28 & E16 & E8.7 & E22 \\
\hline DSL.4 107-111 & 1982 & 200506805 & 7.5 & E63 & 40 & 30 & 15 & 35 \\
\hline DSL.4 130-132 & 1977 & 200504607 & 4.9 & 64 & 41 & 9.5 & 4.3 & 17 \\
\hline DSL.4 136-141 & 1976 & 200504607 & 8.7 & 96 & 77 & 57 & 7.0 & 39 \\
\hline DSL.4 136-141 lab dup & 1976 & 200504607 & $\mathrm{nr}$ & $\mathrm{nr}$ & $\mathrm{nr}$ & $\mathrm{nr}$ & $\mathrm{nr}$ & $\mathrm{nr}$ \\
\hline DSL.5 51-58 & 1987 & 200504607 & 5.7 & 6.6 & 15 & 14 & 9.1 & 15 \\
\hline DSL.5 58-64 & 1985 & 200504607 & 22 & 180 & 140 & 130 & 18 & 75 \\
\hline DSL.5 69-73 & 1982 & 200504607 & 350 & $\mathrm{E} 1,000$ & E900 & E610 & 280 & E690 \\
\hline DSL.6 45-51 & -- & 200504607 & 14 & 13 & 94 & 76 & 19 & 36 \\
\hline \multicolumn{9}{|l|}{ Sediment-quality guidelines } \\
\hline $\begin{array}{l}\text { Threshold effect concentration } \\
\text { (TEC) }\end{array}$ & -- & none & -- & -- & -- & -- & -- & -- \\
\hline $\begin{array}{l}\text { Probable effect concentration } \\
\text { (PEC) }\end{array}$ & -- & none & -- & -- & -- & -- & -- & -- \\
\hline \multicolumn{9}{|l|}{ Quality assurance samples } \\
\hline Lab blank & -- & 200503908 & $\mathrm{nr}$ & $\mathrm{nr}$ & $\mathrm{nr}$ & $\mathrm{nr}$ & $\mathrm{nr}$ & $\mathrm{nr}$ \\
\hline $\begin{array}{l}\text { Lab spike, in percent recovered } \\
\text { (acceptable range) }\end{array}$ & -- & 200503908 & $\mathrm{nr}$ & $\mathrm{nr}$ & $\mathrm{nr}$ & $\mathrm{nr}$ & $\mathrm{nr}$ & $\mathrm{nr}$ \\
\hline Lab blank & -- & 200504607 & $\mathrm{nr}$ & $\mathrm{nr}$ & $\mathrm{nr}$ & $\mathrm{nr}$ & $\mathrm{nr}$ & $\mathrm{nr}$ \\
\hline $\begin{array}{l}\text { Lab spike, in percent recovered } \\
\text { (acceptable range) }\end{array}$ & -- & 200504607 & $\mathrm{nr}$ & $\mathrm{nr}$ & $\mathrm{nr}$ & $\mathrm{nr}$ & $\mathrm{nr}$ & $\mathrm{nr}$ \\
\hline Lab blank & -- & 200506805 & $\mathrm{nr}$ & $\mathrm{nr}$ & $\mathrm{nr}$ & $\mathrm{nr}$ & $\mathrm{nr}$ & $\mathrm{nr}$ \\
\hline $\begin{array}{l}\text { Lab spike, in percent recovered } \\
\text { (acceptable range) }\end{array}$ & -- & 200506805 & $\mathrm{nr}$ & $\mathrm{nr}$ & $\mathrm{nr}$ & $\mathrm{nr}$ & $\mathrm{nr}$ & $\mathrm{nr}$ \\
\hline
\end{tabular}


Appendix 1. Analytical results for selected chlorinated hydrocarbon compounds from samples collected 0ctober 5, 2004, from Devils Swamp Lake, Louisiana-Continued.

\begin{tabular}{|c|c|c|c|c|c|c|c|c|c|c|}
\hline $\begin{array}{c}\text { Sample ID and interval } \\
\text { (centimeters), where applicable }\end{array}$ & $\begin{array}{l}\text { Estimated } \\
\text { deposition } \\
\text { date }\end{array}$ & $\begin{array}{l}\text { Laboratory } \\
\text { set number }\end{array}$ & $\begin{array}{l}\text { PCB } \\
49\end{array}$ & $\begin{array}{l}\text { PCB } \\
52\end{array}$ & $\begin{array}{l}\text { PCB } \\
70\end{array}$ & $\begin{array}{l}\text { PCB } \\
95\end{array}$ & $\begin{array}{l}\text { PCB } \\
101\end{array}$ & $\begin{array}{c}\text { PCB } \\
110\end{array}$ & $\begin{array}{c}\text { PCB } \\
118\end{array}$ & $\begin{array}{l}\text { PCB } \\
138\end{array}$ \\
\hline DSL.2 30-35 & 2001 & 200503908 & 30 & 21 & 16 & 50 & 32 & 44 & 48 & 38 \\
\hline DSL.2 114-116 & 1984 & 200503908 & 69 & 32 & 22 & 74 & 34 & 50 & 61 & 33 \\
\hline DSL.2 136-141 & 1977 & 200503908 & E96 & 47 & 7.3 & 31 & 15 & 38 & 25 & 26 \\
\hline DSL.C & -- & 200506805 & E55 & E52 & E55 & E120 & E90 & E120 & E110 & E110 \\
\hline DSL.4 0-5 & 2004 & 200503908 & 22 & 17 & 19 & 49 & 32 & 47 & 58 & 48 \\
\hline DSL.4 30-35 & 1999 & 200503908 & 14 & 9.0 & 9.4 & 28 & 16 & 22 & 24 & 16 \\
\hline DSL.4 50-55 & 1995 & 200503908 & 14 & 10 & 13 & 32 & 18 & 18 & 25 & 13 \\
\hline DSL.4 80-85 & 1988 & 200503908 & 24 & 18 & 23 & 59 & 34 & 38 & 48 & 36 \\
\hline DSL.4 80-85 lab dup & 1988 & 200503908 & 39 & 22 & 24 & 61 & 34 & 43 & 50 & 35 \\
\hline DSL.4 99-104 & 1984 & 200503908 & E84 & E46 & E11 & E63 & E29 & E50 & E49 & E39 \\
\hline DSL.4 107-111 & 1982 & 200506805 & E120 & E76 & 18 & 68 & 48 & E61 & 48 & 42 \\
\hline DSL.4 130-132 & 1977 & 200504607 & 69 & 61 & 41 & 86 & 44 & 69 & 61 & 56 \\
\hline DSL.4 136-141 & 1976 & 200504607 & 140 & 99 & 70 & 130 & 65 & 100 & 83 & 84 \\
\hline DSL.4 136-141 lab dup & 1976 & 200504607 & $\mathrm{nr}$ & $\mathrm{nr}$ & $\mathrm{nr}$ & $\mathrm{nr}$ & $\mathrm{nr}$ & $\mathrm{nr}$ & $\mathrm{nr}$ & $\mathrm{nr}$ \\
\hline DSL.5 51-58 & 1987 & 200504607 & 78 & 58 & 68 & 120 & 60 & 63 & 64 & 49 \\
\hline DSL.5 58-64 & 1985 & 200504607 & 200 & 220 & 200 & 310 & 160 & 230 & 190 & 180 \\
\hline DSL.5 69-73 & 1982 & 200504607 & $\mathrm{E} 1,400$ & E980 & 240 & E690 & 270 & E810 & 320 & E510 \\
\hline DSL.6 45-51 & -- & 200504607 & 120 & 110 & 130 & 190 & 110 & 120 & 100 & 36 \\
\hline \multicolumn{11}{|l|}{ Sediment-quality guidelines } \\
\hline Threshold effect concentration (TEC) & -- & none & -- & -- & -- & -- & -- & -- & -- & -- \\
\hline Probable effect concentration (PEC) & -- & none & -- & -- & -- & -- & -- & -- & -- & -- \\
\hline \multicolumn{11}{|l|}{ Quality assurance samples } \\
\hline Lab blank & -- & 200503908 & $\mathrm{nr}$ & $\mathrm{nr}$ & $\mathrm{nr}$ & $\mathrm{nr}$ & $\mathrm{nr}$ & $\mathrm{nr}$ & $\mathrm{nr}$ & $\mathrm{nr}$ \\
\hline $\begin{array}{l}\text { Lab spike, in percent recovered } \\
\text { (acceptable range) }\end{array}$ & -- & 200503908 & $\mathrm{nr}$ & $\mathrm{nr}$ & $\mathrm{nr}$ & $\mathrm{nr}$ & $\mathrm{nr}$ & $\mathrm{nr}$ & $\mathrm{nr}$ & $\mathrm{nr}$ \\
\hline Lab blank & -- & 200504607 & $\mathrm{nr}$ & $\mathrm{nr}$ & $\mathrm{nr}$ & $\mathrm{nr}$ & $\mathrm{nr}$ & $\mathrm{nr}$ & $\mathrm{nr}$ & $\mathrm{nr}$ \\
\hline $\begin{array}{l}\text { Lab spike, in percent recovered } \\
\text { (acceptable range) }\end{array}$ & -- & 200504607 & $\mathrm{nr}$ & $\mathrm{nr}$ & $\mathrm{nr}$ & $\mathrm{nr}$ & $\mathrm{nr}$ & $\mathrm{nr}$ & $\mathrm{nr}$ & $\mathrm{nr}$ \\
\hline Lab blank & -- & 200506805 & $\mathrm{nr}$ & $\mathrm{nr}$ & $\mathrm{nr}$ & $\mathrm{nr}$ & $\mathrm{nr}$ & $\mathrm{nr}$ & $\mathrm{nr}$ & $\mathrm{nr}$ \\
\hline $\begin{array}{l}\text { Lab spike, in percent recovered } \\
\text { (acceptable range) }\end{array}$ & -- & 200506805 & $\mathrm{nr}$ & $\mathrm{nr}$ & $\mathrm{nr}$ & $\mathrm{nr}$ & $\mathrm{nr}$ & $\mathrm{nr}$ & $\mathrm{nr}$ & $\mathrm{nr}$ \\
\hline
\end{tabular}




\section{Sources of Polychlorinated Biphenyls to Devils Swamp Lake Near Baton Rouge, Louisiana}

Appendix 1. Analytical results for selected chlorinated hydrocarbon compounds from samples collected 0ctober 5, 2004, from Devils Swamp Lake, Louisiana-Continued.

\begin{tabular}{|c|c|c|c|c|c|c|c|c|c|c|}
\hline $\begin{array}{c}\text { Sample ID and interval } \\
\text { (centimeters), where applicable }\end{array}$ & $\begin{array}{l}\text { Estimated } \\
\text { deposition } \\
\text { date }\end{array}$ & $\begin{array}{l}\text { Laboratory } \\
\text { set number }\end{array}$ & $\begin{array}{l}\text { PCB } \\
146\end{array}$ & $\begin{array}{l}\text { PCB } \\
149\end{array}$ & $\begin{array}{l}\text { PCB } \\
151\end{array}$ & $\begin{array}{l}\text { PCB } \\
170\end{array}$ & $\begin{array}{l}\text { PCB } \\
174\end{array}$ & $\begin{array}{l}\text { PCB } \\
177\end{array}$ & $\begin{array}{c}\text { PCB } \\
180\end{array}$ & $\begin{array}{c}\text { PCB } \\
183\end{array}$ \\
\hline DSL.2 114-116 & 1984 & 200503908 & 6.5 & 24 & 5.7 & 6.2 & 5.3 & 3.9 & 11 & 3.2 \\
\hline DSL.2 136-141 & 1977 & 200503908 & 5.8 & 19 & 3.6 & 5.2 & 3.4 & 3.2 & 8.6 & 2.2 \\
\hline DSL.C & -- & 200506805 & 19 & E54 & 17 & 18 & 12 & 9.2 & 27 & 8.0 \\
\hline DSL.4 0-5 & 2004 & 200503908 & 6.8 & 24 & 6.0 & 9.5 & 6.8 & 4.5 & 15 & 4.1 \\
\hline DSL.4 30-35 & 1999 & 200503908 & 3.2 & 12 & 2.1 & 3.8 & 2.6 & 2.0 & 6.4 & 1.7 \\
\hline DSL.4 99-104 & 1984 & 200503908 & E8.8 & E25 & $<10$ & E8.5 & E5.0 & $<10$ & E13 & $<10$ \\
\hline DSL.4 107-111 & 1982 & 200506805 & 10 & 40 & 14 & 12 & 10 & 6.9 & 19 & 6.2 \\
\hline DSL.4 130-132 & 1977 & 200504607 & 8.6 & 41 & 7.8 & 7.5 & 7.0 & 5.8 & 9.8 & 3.5 \\
\hline DSL.4 136-141 & 1976 & 200504607 & 11 & 70 & 11 & 10 & 9.5 & 7.6 & 38 & 2.9 \\
\hline DSL.4 136-141 lab dup & 1976 & 200504607 & $\mathrm{nr}$ & $\mathrm{nr}$ & $\mathrm{nr}$ & $\mathrm{nr}$ & $\mathrm{nr}$ & $\mathrm{nr}$ & $\mathrm{nr}$ & $\mathrm{nr}$ \\
\hline DSL.5 51-58 & 1987 & 200504607 & 8.8 & 53 & 8.7 & 8.4 & 7.6 & 6.1 & 12 & 5.6 \\
\hline \multicolumn{11}{|l|}{ Sediment-quality guidelines } \\
\hline Threshold effect concentration (TEC) & -- & none & -- & -- & -- & -- & -- & -- & -- & -- \\
\hline Probable effect concentration (PEC) & -- & none & -- & -- & -- & -- & -- & -- & -- & -- \\
\hline \multicolumn{11}{|l|}{ Quality assurance samples } \\
\hline Lab blank & -- & 200503908 & $\mathrm{nr}$ & $\mathrm{nr}$ & $\mathrm{nr}$ & $\mathrm{nr}$ & $\mathrm{nr}$ & $\mathrm{nr}$ & $\mathrm{nr}$ & $\mathrm{nr}$ \\
\hline $\begin{array}{l}\text { Lab spike, in percent recovered } \\
\text { (acceptable range) }\end{array}$ & -- & 200503908 & $\mathrm{nr}$ & $\mathrm{nr}$ & $\mathrm{nr}$ & $\mathrm{nr}$ & $\mathrm{nr}$ & $\mathrm{nr}$ & $\mathrm{nr}$ & $\mathrm{nr}$ \\
\hline Lab blank & -- & 200504607 & $\mathrm{nr}$ & $\mathrm{nr}$ & $\mathrm{nr}$ & $\mathrm{nr}$ & $\mathrm{nr}$ & $\mathrm{nr}$ & $\mathrm{nr}$ & $\mathrm{nr}$ \\
\hline $\begin{array}{l}\text { Lab spike, in percent recovered } \\
\text { (acceptable range) }\end{array}$ & -- & 200504607 & $\mathrm{nr}$ & $\mathrm{nr}$ & $\mathrm{nr}$ & $\mathrm{nr}$ & $\mathrm{nr}$ & $\mathrm{nr}$ & $\mathrm{nr}$ & $\mathrm{nr}$ \\
\hline Lab blank & -- & 200506805 & $\mathrm{nr}$ & $\mathrm{nr}$ & $\mathrm{nr}$ & $\mathrm{nr}$ & $\mathrm{nr}$ & $\mathrm{nr}$ & $\mathrm{nr}$ & $\mathrm{nr}$ \\
\hline $\begin{array}{l}\text { Lab spike, in percent recovered } \\
\text { (acceptable range) }\end{array}$ & -- & 200506805 & $\mathrm{nr}$ & $\mathrm{nr}$ & $\mathrm{nr}$ & $\mathrm{nr}$ & $\mathrm{nr}$ & $\mathrm{nr}$ & $\mathrm{nr}$ & $\mathrm{nr}$ \\
\hline
\end{tabular}


Appendix 1. Analytical results for selected chlorinated hydrocarbon compounds from samples collected 0 ctober 5, 2004, from Devils Swamp Lake, Louisiana-Continued.

\begin{tabular}{|c|c|c|c|c|c|c|c|c|}
\hline \multirow{2}{*}{$\begin{array}{c}\text { Sample ID and interval } \\
\text { (centimeters), where applicable }\end{array}$} & \multirow{2}{*}{$\begin{array}{c}\text { Estimated } \\
\text { deposition } \\
\text { date }\end{array}$} & \multirow{2}{*}{$\begin{array}{l}\text { Laboratory } \\
\text { set number }\end{array}$} & \multirow{2}{*}{$\begin{array}{l}\text { PCB } \\
187\end{array}$} & \multirow{2}{*}{$\begin{array}{l}\text { PCB } \\
194\end{array}$} & \multirow{2}{*}{$\begin{array}{l}\text { PCB } \\
206\end{array}$} & \multicolumn{3}{|c|}{ Calculated values } \\
\hline & & & & & & $\begin{array}{l}\text { Total } \\
\text { DDT }\end{array}$ & $\Sigma \mathrm{PCB}_{\mathrm{C}}$ & $\Sigma \mathrm{PCB}_{\mathrm{A}}$ \\
\hline DSL.2 30-35 & 2001 & 200503908 & 11 & 4.1 & E1.0 & E1.8 & E440 & 760 \\
\hline DSL.2 114-116 & 1984 & 200503908 & 6.4 & 2.1 & E. 8 & E1.5 & E580 & 910 \\
\hline DSL.2 136-141 & 1977 & 200503908 & 6.5 & 2.1 & E.7 & E3.0 & E460 & 610 \\
\hline DSL.C & -- & 200506805 & 15 & 4.8 & 1.3 & E15 & E970 & $\mathbf{E} 1,300$ \\
\hline DSL.4 0-5 & 2004 & 200503908 & 7.2 & 2.8 & E.7 & E2.0 & $\mathrm{E} 420$ & 790 \\
\hline DSL.4 30-35 & 1999 & 200503908 & 3.4 & 1.3 & $<1.0$ & E1.8 & E200 & 360 \\
\hline DSL.4 50-55 & 1995 & 200503908 & 4.2 & 1.5 & $<1.0$ & E1.1 & E210 & 350 \\
\hline DSL.4 80-85 & 1988 & 200503908 & 7.1 & 2.4 & E.6 & E2.5 & $\mathrm{E} 400$ & 670 \\
\hline DSL.4 80-85 lab dup & 1988 & 200503908 & 7.2 & 2.3 & E.7 & E2.3 & E440 & 680 \\
\hline DSL.4 99-104 & 1984 & 200503908 & E8.5 & $<10$ & $<10$ & $<50$ & E580 & E780 \\
\hline DSL.4 107-111 & 1982 & 200506805 & 13 & 4.3 & 1.3 & E8.7 & E830 & 1,000 \\
\hline DSL.4 130-132 & 1977 & 200504607 & 8.3 & 3.9 & 1.4 & E4.3 & 750 & 1,200 \\
\hline DSL.4 136-141 & 1976 & 200504607 & 11 & 5.8 & 2.3 & $\mathrm{E} 4.2$ & 1,300 & 1,900 \\
\hline DSL.4 136-141 lab dup & 1976 & 200504607 & $\mathrm{nr}$ & $\mathrm{nr}$ & $\mathrm{nr}$ & E3.8 & -- & 2,000 \\
\hline DSL.5 51-58 & 1987 & 200504607 & 9.0 & 4.0 & E1.0 & E4.3 & E770 & 1,100 \\
\hline DSL.5 58-64 & 1985 & 200504607 & 26 & 12 & 3.3 & 23 & 2,800 & 3,000 \\
\hline DSL.5 69-73 & 1982 & 200504607 & 190 & 84 & 28 & 56 & E12,000 & $\mathbf{E 2 0 , 0 0 0}$ \\
\hline DSL.6 45-51 & -- & 200504607 & 12 & 5.0 & E. 5 & E7.9 & E1,400 & 2,100 \\
\hline \multicolumn{9}{|l|}{ Sediment-quality guidelines } \\
\hline Threshold effect concentration (TEC) & -- & none & -- & -- & -- & 5.28 & 59.8 & 59.8 \\
\hline Probable effect concentration (PEC) & -- & none & -- & -- & -- & 572 & 676 & 676 \\
\hline \multicolumn{9}{|l|}{ Quality assurance samples } \\
\hline Lab blank & -- & 200503908 & $\mathrm{nr}$ & $\mathrm{nr}$ & $\mathrm{nr}$ & -- & -- & -- \\
\hline $\begin{array}{l}\text { Lab spike, in percent recovered } \\
\text { (acceptable range) }\end{array}$ & -- & 200503908 & $\mathrm{nr}$ & $\mathrm{nr}$ & $\mathrm{nr}$ & -- & -- & -- \\
\hline Lab blank & -- & 200504607 & $\mathrm{nr}$ & $\mathrm{nr}$ & $\mathrm{nr}$ & -- & -- & -- \\
\hline $\begin{array}{l}\text { Lab spike, in percent recovered } \\
\text { (acceptable range) }\end{array}$ & -- & 200504607 & $\mathrm{nr}$ & $\mathrm{nr}$ & $\mathrm{nr}$ & -- & -- & -- \\
\hline Lab blank & -- & 200506805 & $\mathrm{nr}$ & $\mathrm{nr}$ & $\mathrm{nr}$ & -- & -- & -- \\
\hline $\begin{array}{l}\text { Lab spike, in percent recovered } \\
\text { (acceptable range) }\end{array}$ & -- & 200506805 & $\mathrm{nr}$ & $\mathrm{nr}$ & $\mathrm{nr}$ & -- & -- & -- \\
\hline
\end{tabular}


Appendix 1. Analytical results for selected chlorinated hydrocarbon compounds from samples collected 0ctober 5, 2004, from Devils Swamp Lake, Louisiana-Continued.

\begin{tabular}{|c|c|c|c|c|c|c|}
\hline \multirow{2}{*}{$\begin{array}{c}\text { Sample ID and interval } \\
\text { (centimeters), where applicable }\end{array}$} & \multirow{2}{*}{$\begin{array}{l}\text { Estimated } \\
\text { deposition } \\
\text { date }\end{array}$} & \multirow{2}{*}{$\begin{array}{l}\text { Laboratory } \\
\text { set number }\end{array}$} & \multicolumn{3}{|c|}{$\begin{array}{l}\text { Surrogates, in percent recovered } \\
\text { (acceptable recovery limits) }\end{array}$} & \multirow{2}{*}{$\begin{array}{c}\text { Sample } \\
\text { mass } \\
\text { (grams) }\end{array}$} \\
\hline & & & $\begin{array}{l}\text { Isodrin } \\
\text { (42-94) }\end{array}$ & $\begin{array}{l}\text { alpha- } \\
\text { HCH-d6 } \\
(19-125)\end{array}$ & $\begin{array}{c}\text { Nonachloro- } \\
\text { biphenyl } \\
(21-140)\end{array}$ & \\
\hline DSL.2 30-35 & 2001 & 200503908 & 84 & 70 & 82 & 13.7 \\
\hline DSL.2 114-116 & 1984 & 200503908 & 82 & 63 & 84 & 12.4 \\
\hline DSL.2 136-141 & 1977 & 200503908 & 77 & 72 & 72 & 16.8 \\
\hline DSL.C & -- & 200506805 & 77 & 61 & 79 & 20.7 \\
\hline DSL.4 0-5 & 2004 & 200503908 & 77 & 72 & 72 & 16.8 \\
\hline DSL.4 30-35 & 1999 & 200503908 & 80 & 72 & 73 & 17.4 \\
\hline DSL.4 50-55 & 1995 & 200503908 & 82 & 67 & 93 & 15.7 \\
\hline DSL.4 80-85 & 1988 & 200503908 & 78 & 67 & 87 & 16.0 \\
\hline DSL.4 80-85 lab dup & 1988 & 200503908 & 77 & 70 & 82 & 15.7 \\
\hline DSL.4 99-104 & 1984 & 200503908 & 78 & 66 & 48 & 15.0 \\
\hline DSL.4 107-111 & 1982 & 200506805 & 69 & 63 & 78 & 13.8 \\
\hline DSL.4 130-132 & 1977 & 200504607 & 111 & 63 & 68 & 15.6 \\
\hline DSL.4 136-141 & 1976 & 200504607 & $\mathrm{nr}$ & 81 & 76 & 16.9 \\
\hline DSL.4 136-141 lab dup & 1976 & 200504607 & $\mathrm{nr}$ & 87 & 79 & 16.9 \\
\hline DSL.5 51-58 & 1987 & 200504607 & 82 & 82 & 69 & 15.5 \\
\hline DSL.5 58-64 & 1985 & 200504607 & 89 & 89 & 71 & 8.7 \\
\hline DSL.5 69-73 & 1982 & 200504607 & $\mathrm{nr}$ & 60 & 118 & 14.2 \\
\hline DSL.6 45-51 & -- & 200504607 & 76 & 75 & 66 & 14.3 \\
\hline \multicolumn{7}{|l|}{ Sediment-quality guidelines } \\
\hline Threshold effect concentration (TEC) & -- & none & -- & -- & -- & -- \\
\hline Probable effect concentration (PEC) & -- & none & -- & -- & -- & -- \\
\hline \multicolumn{7}{|l|}{ Quality assurance samples } \\
\hline Lab blank & -- & 200503908 & 80 & 57 & 87 & 25.0 \\
\hline $\begin{array}{l}\text { Lab spike, in percent recovered } \\
\text { (acceptable range) }\end{array}$ & -- & 200503908 & $\mathrm{nr}$ & $\mathrm{nr}$ & $\mathrm{nr}$ & 25.0 \\
\hline Lab blank & -- & 200504607 & $\mathrm{nr}$ & $\mathrm{nr}$ & $\mathrm{nr}$ & 25.0 \\
\hline $\begin{array}{l}\text { Lab spike, in percent recovered } \\
\text { (acceptable range) }\end{array}$ & -- & 200504607 & 72 & 70 & 83 & 25.0 \\
\hline Lab blank & -- & 200506805 & 70 & 54 & 84 & 25.0 \\
\hline $\begin{array}{l}\text { Lab spike, in percent recovered } \\
\text { (acceptable range) }\end{array}$ & -- & 200506805 & 70 & 55 & 82 & 25.0 \\
\hline
\end{tabular}


Appendix 2-Analytical Results for

Polycyclic Aromatic Hydrocarbons 
Blank Page 
Appendix 2. Analytical results for polycyclic aromatic hydrocarbons from samples collected October 5, 2004, from Devils Swamp Lake, Louisiana.

[In micrograms per kilogram except as indicated. Concentration in bold exceeds probable effect concentration (MacDonald and others, 2000). ID, identifier; $<$, nondetection at indicated value; E, estimated value; --, not calculated; lab, laboratory; na, not analyzed; nr, not reported; $\Sigma$ PAH $\mathrm{SQG}_{\mathrm{G}}$, sum of selected polycyclic aromatic hydrocarbons (PAHs) used for probable effect concentration; PAH 2+3/comb ratio, sum of 2- and 3-ringed PAHs plus alkyl-PAH divided by sum of 4- and 5- ringed parent PAHs]

\begin{tabular}{|c|c|c|c|c|c|c|c|}
\hline $\begin{array}{c}\text { Sample ID and interval } \\
\text { (centimeters), where applicable }\end{array}$ & $\begin{array}{l}\text { Estimated } \\
\text { deposition } \\
\text { date }\end{array}$ & $\begin{array}{l}\text { Laboratory } \\
\text { set number }\end{array}$ & $\begin{array}{l}\text { Naphtha- } \\
\text { lene }\end{array}$ & $\begin{array}{c}\text { C1-128 } \\
\text { Isomers, } \\
\text { methylated } \\
\text { naphthalenes }\end{array}$ & $\begin{array}{l}\text { 2-Ethyl- } \\
\text { naphthalene }\end{array}$ & $\begin{array}{c}2,6- \\
\text { Dimethyl- } \\
\text { naphthalene }\end{array}$ & $\begin{array}{l}1,6- \\
\text { Dimethyl- } \\
\text { naphtha- } \\
\text { lene }\end{array}$ \\
\hline DSL.2 30-35 & 2001 & 200503907 & $<18$ & E160 & $<18$ & 150 & 21 \\
\hline DSL.2 114-116 & 1984 & 200503907 & $<20$ & E78 & $<20$ & 160 & 27 \\
\hline DSL.C & -- & 200506806 & $<12$ & $<12$ & $<12$ & $<12$ & $<12$ \\
\hline DSL.4 0-5 & 2004 & 200503907 & $<16$ & E65 & $<16$ & 63 & $<16$ \\
\hline DSL.4 30-35 & 1999 & 200503907 & $<14$ & E66 & $<14$ & 51 & $<14$ \\
\hline DSL.4 99-104 & 1984 & 200503907 & E7.4 & 38 & $<19$ & 30 & $<19$ \\
\hline DSL.4 107-111 & 1982 & 200506806 & $<18$ & E6.6 & $<18$ & 100 & 42 \\
\hline DSL.4 130-132 & 1977 & 200504608 & E13 & E140 & E15 & 76 & 18 \\
\hline DSL.4 136-141 & 1976 & 200504608 & $<15$ & E220 & 24 & 90 & 23 \\
\hline DSL.5 58-64 & 1985 & 200504608 & $<29$ & $\mathrm{E} 1,000$ & 150 & 270 & 120 \\
\hline DSL.5 69-73 & 1982 & 200504608 & 54 & $\mathrm{E} 1,400$ & 320 & 740 & 430 \\
\hline \multicolumn{8}{|l|}{ Quality assurance samples } \\
\hline Lab blank & -- & 200503907 & $<10$ & na & $<10$ & $<10$ & $<10$ \\
\hline $\begin{array}{l}\text { Lab spike, in percent recovered } \\
\text { (acceptable range) }\end{array}$ & -- & 200503907 & $68.7(49-94)$ & na & $69.0(36-92)$ & $70.3(33-94)$ & $69.4(37-89)$ \\
\hline Lab blank & -- & 200504608 & $\mathrm{nr}$ & na & $\mathrm{nr}$ & $\mathrm{nr}$ & $\mathrm{nr}$ \\
\hline $\begin{array}{l}\text { Lab spike, in percent recovered } \\
\text { (acceptable range) }\end{array}$ & -- & 200504608 & $61.1(49-94)$ & na & $63.8(36-92)$ & $63.5(33-94)$ & $65.0(37-89)$ \\
\hline Lab blank & -- & 200506807 & $<10$ & na & $<10$ & $<10$ & $<10$ \\
\hline $\begin{array}{l}\text { Lab spike, in percent recovered } \\
\text { (acceptable range) }\end{array}$ & -- & 200506807 & $73.3(49-94)$ & na & $66.4(36-92)$ & $63.8(33-94)$ & $66.9(37-89)$ \\
\hline
\end{tabular}


Appendix 2. Analytical results for polycyclic aromatic hydrocarbons from samples collected October 5, 2004, from Devils Swamp Lake, Louisiana-Continued.

\begin{tabular}{|c|c|c|c|c|c|c|c|}
\hline $\begin{array}{c}\text { Sample ID and interval } \\
\text { (centimeters), where applicable }\end{array}$ & $\begin{array}{l}\text { Estimated } \\
\text { deposition } \\
\text { date }\end{array}$ & $\begin{array}{l}\text { Laboratory } \\
\text { set number }\end{array}$ & $\begin{array}{c}\text { C2-128 } \\
\text { Isomers, } \\
\text { C2-alkyated } \\
\text { naphthalenes }\end{array}$ & $\begin{array}{l}\text { Acenaph- } \\
\text { thylene }\end{array}$ & $\begin{array}{l}\text { 1,2-Dimethyl- } \\
\text { naphtha- } \\
\text { lene }\end{array}$ & $\begin{array}{l}\text { Acenaph- } \\
\text { thene }\end{array}$ & $\begin{array}{c}\text { C3-128 } \\
\text { Isomers, } \\
\text { C3-alkylated } \\
\text { naphthalenes }\end{array}$ \\
\hline DSL.2 30-35 & 2001 & 200503907 & E220 & 69 & $<18$ & $<18$ & $<55$ \\
\hline DSL.2 114-116 & 1984 & 200503907 & E230 & 37 & $<20$ & $<20$ & E86 \\
\hline DSL.2 136-141 & 1977 & 200503907 & E80 & 43 & $<15$ & E14 & E55 \\
\hline DSL.C & -- & 200506806 & $<12$ & 40 & $<12$ & $<12$ & $<12$ \\
\hline DSL.4 0-5 & 2004 & 200503907 & E100 & 40 & $<16$ & $<16$ & E45 \\
\hline DSL.4 30-35 & 1999 & 200503907 & E85 & 27 & $<14$ & $<14$ & $<40$ \\
\hline DSL.4 50-55 & 1995 & 200503907 & E90 & 28 & $<16$ & E14 & E50 \\
\hline DSL.4 80-85 & 1988 & 200503907 & E170 & 34 & $<16$ & $<16$ & $<50$ \\
\hline DSL.4 99-104 & 1984 & 200503907 & 78 & 42 & $<19$ & E13 & 88 \\
\hline DSL.4 107-111 & 1982 & 200506806 & E19 & 110 & $<18$ & 32 & E12 \\
\hline DSL.4 130-132 & 1977 & 200504608 & E180 & 180 & $<16$ & 18 & E200 \\
\hline DSL.4 136-141 & 1976 & 200504608 & E220 & 260 & $<15$ & 24 & E190 \\
\hline DSL.5 58-64 & 1985 & 200504608 & $\mathrm{E} 1,500$ & 1,600 & 56 & 220 & $\mathrm{E} 2,200$ \\
\hline DSL.5 69-73 & 1982 & 200504608 & $\mathrm{E} 4,000$ & 1,400 & 140 & 410 & E6,900 \\
\hline DSL.6 45-51 & -- & 200504608 & E270 & 290 & $<17$ & 31 & $<270$ \\
\hline \multicolumn{8}{|l|}{ Sediment-quality guidelines } \\
\hline Threshold effect concentration (TEC) & -- & none & -- & -- & -- & -- & -- \\
\hline Probable effect concentration (PEC) & -- & none & -- & -- & -- & -- & -- \\
\hline \multicolumn{8}{|l|}{ Quality assurance samples } \\
\hline Lab blank & -- & 200503907 & na & $<10$ & $<10$ & $<10$ & na \\
\hline $\begin{array}{l}\text { Lab spike, in percent recovered } \\
\text { (acceptable range) }\end{array}$ & -- & 200503907 & na & $69.8(33-84)$ & $69.3(44-89)$ & $71.1(49-81)$ & na \\
\hline Lab blank & -- & 200504608 & na & $\mathrm{nr}$ & $\mathrm{nr}$ & $\mathrm{nr}$ & na \\
\hline $\begin{array}{l}\text { Lab spike, in percent recovered } \\
\text { (acceptable range) }\end{array}$ & -- & 200504608 & na & $67.2(33-84)$ & $65.3(44-89)$ & $70.9(49-81)$ & na \\
\hline Lab blank & -- & 200506807 & na & $<10$ & $<10$ & $<10$ & na \\
\hline $\begin{array}{l}\text { Lab spike, in percent recovered } \\
\text { (acceptable range) }\end{array}$ & -- & 200506807 & na & $71.3(33-84)$ & $73.1(44-89)$ & $72.9(49-81)$ & na \\
\hline
\end{tabular}


Appendix 2. Analytical results for polycyclic aromatic hydrocarbons from samples collected October 5, 2004, from Devils Swamp Lake, Louisiana-Continued.

\begin{tabular}{|c|c|c|c|c|c|c|c|}
\hline $\begin{array}{c}\text { Sample ID and interval } \\
\text { (centimeters), where applicable }\end{array}$ & $\begin{array}{c}\text { Estimated } \\
\text { deposition } \\
\text { date }\end{array}$ & $\begin{array}{l}\text { Laboratory } \\
\text { set number }\end{array}$ & $\begin{array}{c}2,3,6- \\
\text { Trimethyl- } \\
\text { naphthalene }\end{array}$ & $\begin{array}{l}9 \mathrm{H}- \\
\text { Fluorene }\end{array}$ & $\begin{array}{c}\text { C4-128 } \\
\text { Isomers, } \\
\text { C4-alkylated } \\
\text { naphthalenes }\end{array}$ & $\begin{array}{l}\text { 1-Methyl-9H- } \\
\text { fluorene }\end{array}$ & $\begin{array}{l}\text { Phenan- } \\
\text { threne }\end{array}$ \\
\hline DSL.2 30-35 & 2001 & 200503907 & $<18$ & $<18$ & $<40$ & $<18$ & 26 \\
\hline DSL.2 114-116 & 1984 & 200503907 & $<20$ & $<20$ & $<50$ & $<20$ & 28 \\
\hline DSL.2 136-141 & 1977 & 200503907 & $<15$ & $<15$ & $<45$ & $<15$ & 24 \\
\hline DSL.C & -- & 200506806 & $<12$ & $<12$ & $<12$ & $<12$ & 13 \\
\hline DSL.4 0-5 & 2004 & 200503907 & $<16$ & $<16$ & $<30$ & $<16$ & 19 \\
\hline DSL.4 30-35 & 1999 & 200503907 & $<14$ & $<14$ & $<30$ & $<14$ & 20 \\
\hline DSL.4 50-55 & 1995 & 200503907 & $<16$ & $<16$ & $<40$ & $<16$ & 25 \\
\hline DSL.4 80-85 & 1988 & 200503907 & $<16$ & $<16$ & $<30$ & $<16$ & E16 \\
\hline DSL.4 99-104 & 1984 & 200503907 & $<19$ & $<19$ & $<60$ & $<19$ & 28 \\
\hline DSL.4 107-111 & 1982 & 200506806 & $<18$ & 45 & E8.1 & $<18$ & 39 \\
\hline DSL.4 130-132 & 1977 & 200504608 & 20 & 25 & E160 & $<16$ & 68 \\
\hline DSL.4 136-141 & 1976 & 200504608 & 18 & 33 & $<110$ & $<15$ & 76 \\
\hline DSL.5 58-64 & 1985 & 200504608 & 100 & 200 & E920 & 470 & 270 \\
\hline DSL.5 69-73 & 1982 & 200504608 & 420 & 860 & $\mathrm{E} 3,500$ & 1,100 & 2,400 \\
\hline DSL.6 45-51 & -- & 200504608 & 29 & 40 & $<150$ & $<17$ & 120 \\
\hline \multicolumn{8}{|l|}{ Sediment-quality guidelines } \\
\hline Threshold effect concentration (TEC) & -- & none & -- & 77.4 & -- & -- & 204 \\
\hline Probable effect concentration (PEC) & -- & none & -- & 536 & -- & -- & 1,170 \\
\hline \multicolumn{8}{|l|}{ Quality assurance samples } \\
\hline Lab blank & -- & 200503907 & $<10$ & $<10$ & na & $<10$ & $<10$ \\
\hline $\begin{array}{l}\text { Lab spike, in percent recovered } \\
\text { (acceptable range) }\end{array}$ & -- & 200503907 & $69.6(38-95)$ & $71.0(31-96)$ & na & $71.3(37-97)$ & $73.9(52-90)$ \\
\hline Lab blank & -- & 200504608 & $\mathrm{nr}$ & $\mathrm{nr}$ & na & $\mathrm{nr}$ & $\mathrm{nr}$ \\
\hline $\begin{array}{l}\text { Lab spike, in percent recovered } \\
\text { (acceptable range) }\end{array}$ & -- & 200504608 & $69.6(38-95)$ & $72.3(31-96)$ & na & $78.2(37-97)$ & $81.6(52-90)$ \\
\hline Lab blank & -- & 200506807 & $<10$ & $<10$ & na & $<10$ & $<10$ \\
\hline $\begin{array}{l}\text { Lab spike, in percent recovered } \\
\text { (acceptable range) }\end{array}$ & -- & 200506807 & $71.4(38-95)$ & $71.6(31-96)$ & na & $74.9(37-97)$ & $76.4(52-90)$ \\
\hline
\end{tabular}


Appendix 2. Analytical results for polycyclic aromatic hydrocarbons from samples collected October 5, 2004, from Devils Swamp Lake, Louisiana-Continued.

\begin{tabular}{|c|c|c|c|c|c|c|c|}
\hline $\begin{array}{c}\text { Sample ID and interval } \\
\text { (centimeters), where applicable }\end{array}$ & $\begin{array}{l}\text { Estimated } \\
\text { deposition } \\
\text { date }\end{array}$ & $\begin{array}{l}\text { Laboratory } \\
\text { set number }\end{array}$ & $\begin{array}{l}\text { Anthra- } \\
\text { cene }\end{array}$ & $\begin{array}{l}\text { C5-128 } \\
\text { Isomers, } \\
\text { C5-alkylated } \\
\text { naphtha- } \\
\text { lenes }\end{array}$ & $\begin{array}{l}\text { 2-Methyl- } \\
\text { anthracene }\end{array}$ & $\begin{array}{c}\text { 4,5- } \\
\text { Methylene- } \\
\text { phenan- } \\
\text { threne }\end{array}$ & $\begin{array}{c}\text { C1-178 } \\
\text { Isomers, } \\
\text { methylated } \\
\text { phenanthrene/ } \\
\text { anthracenes }\end{array}$ \\
\hline DSL.2 30-35 & 2001 & 200503907 & 48 & $<18$ & $<18$ & $<18$ & E75 \\
\hline DSL.2 114-116 & 1984 & 200503907 & 29 & $<20$ & $<20$ & $<20$ & $<70$ \\
\hline DSL.2 136-141 & 1977 & 200503907 & 40 & $<15$ & $<15$ & 18 & E47 \\
\hline DSL.C & -- & 200506806 & 27 & $<12$ & $<12$ & $<12$ & $<12$ \\
\hline DSL.4 0-5 & 2004 & 200503907 & 25 & $<16$ & $<16$ & $<16$ & E56 \\
\hline DSL.4 30-35 & 1999 & 200503907 & 21 & $<14$ & $<14$ & $<14$ & E48 \\
\hline DSL.4 50-55 & 1995 & 200503907 & 22 & $<16$ & $<16$ & $<16$ & E52 \\
\hline DSL.4 80-85 & 1988 & 200503907 & 21 & $<16$ & $<16$ & $<16$ & E44 \\
\hline DSL.4 99-104 & 1984 & 200503907 & 25 & $<20$ & $<19$ & E12 & 50 \\
\hline DSL.4 107-111 & 1982 & 200506806 & 62 & $<18$ & $<18$ & 26 & E9.7 \\
\hline DSL.4 130-132 & 1977 & 200504608 & 98 & $<45$ & $<16$ & 22 & E150 \\
\hline DSL.4 136-141 & 1976 & 200504608 & 130 & $<35$ & 30 & 34 & E120 \\
\hline DSL.5 58-64 & 1985 & 200504608 & 1,300 & $<170$ & 300 & 1,100 & $\mathrm{E} 1,900$ \\
\hline DSL.5 69-73 & 1982 & 200504608 & 1,700 & E440 & 440 & 1,400 & $\mathrm{E} 5,900$ \\
\hline DSL.6 45-51 & -- & 200504608 & 200 & $<45$ & 54 & 73 & E300 \\
\hline \multicolumn{8}{|l|}{ Sediment-quality guidelines } \\
\hline Threshold effect concentration (TEC) & -- & none & 57.2 & -- & -- & -- & -- \\
\hline Probable effect concentration (PEC) & -- & none & 845 & -- & -- & -- & -- \\
\hline \multicolumn{8}{|l|}{ Quality assurance samples } \\
\hline Lab blank & -- & 200503907 & $<10$ & na & $<10$ & $<10$ & na \\
\hline $\begin{array}{l}\text { Lab spike, in percent recovered } \\
\text { (acceptable range) }\end{array}$ & -- & 200503907 & $69.5(44-77)$ & na & 70.7 (27-93) & $74.2(53-90)$ & na \\
\hline Lab blank & -- & 200504608 & $\mathrm{nr}$ & na & $\mathrm{nr}$ & $\mathrm{nr}$ & na \\
\hline $\begin{array}{l}\text { Lab spike, in percent recovered } \\
\text { (acceptable range) }\end{array}$ & -- & 200504608 & $76.0(44-77)$ & na & $78.3(27-93)$ & $82.0(53-90)$ & na \\
\hline Lab blank & -- & 200506807 & $<10$ & na & $<10$ & $<10$ & na \\
\hline $\begin{array}{l}\text { Lab spike, in percent recovered } \\
\text { (acceptable range) }\end{array}$ & -- & 200506807 & $72.4(44-77)$ & na & $72.6(27-93)$ & $78.9(53-90)$ & na \\
\hline
\end{tabular}


Appendix 2. Analytical results for polycyclic aromatic hydrocarbons from samples collected October 5, 2004, from Devils Swamp Lake, Louisiana-Continued.

\begin{tabular}{|c|c|c|c|c|c|c|c|}
\hline $\begin{array}{c}\text { Sample ID and interval } \\
\text { (centimeters), where applicable }\end{array}$ & $\begin{array}{l}\text { Estimated } \\
\text { deposition } \\
\text { date }\end{array}$ & $\begin{array}{l}\text { Laboratory } \\
\text { set number }\end{array}$ & $\begin{array}{l}\text { 1-Methyl- } \\
\text { phenanthrene }\end{array}$ & $\begin{array}{l}\text { C2-178 Isomers, } \\
\text { C2-alkylated } \\
\text { phenanthrene/ } \\
\text { anthracenes }\end{array}$ & Fluoranthene & Pyrene & $\begin{array}{c}\text { C3-178 } \\
\text { Isomers, } \\
\text { C3-alkylated } \\
\text { phenanthrene/ } \\
\text { anthracenes }\end{array}$ \\
\hline DSL.2 30-35 & 2001 & 200503907 & $<18$ & E61 & 37 & 55 & E63 \\
\hline DSL.2 114-116 & 1984 & 200503907 & $<20$ & $<70$ & 30 & 40 & $<40$ \\
\hline DSL.2 136-141 & 1977 & 200503907 & $<15$ & E52 & 72 & 69 & E47 \\
\hline DSL.C & -- & 200506806 & $<12$ & $<12$ & 16 & 17 & $<12$ \\
\hline DSL.4 0-5 & 2004 & 200503907 & $<16$ & E47 & 29 & 41 & E46 \\
\hline DSL.4 30-35 & 1999 & 200503907 & $<14$ & E50 & 25 & 35 & E40 \\
\hline DSL.4 50-55 & 1995 & 200503907 & $<16$ & E56 & 27 & 38 & $<45$ \\
\hline DSL.4 80-85 & 1988 & 200503907 & $<16$ & E41 & 21 & 28 & $<40$ \\
\hline DSL.4 99-104 & 1984 & 200503907 & $<19$ & 69 & 34 & 38 & 24 \\
\hline DSL.4 107-111 & 1982 & 200506806 & 26 & E9.8 & 50 & 69 & E9.4 \\
\hline DSL.4 130-132 & 1977 & 200504608 & $<16$ & E200 & 82 & 110 & E150 \\
\hline DSL.4 136-141 & 1976 & 200504608 & $<15$ & E110 & 69 & 130 & E100 \\
\hline DSL.5 58-64 & 1985 & 200504608 & 880 & $\mathrm{E} 1,000$ & 1,900 & 2,800 & E680 \\
\hline DSL.5 69-73 & 1982 & 200504608 & 1,200 & E6,600 & 1,800 & 2,600 & $\mathrm{E} 5,500$ \\
\hline DSL.6 45-51 & -- & 200504608 & 56 & E390 & 170 & 340 & E460 \\
\hline \multicolumn{8}{|l|}{ Sediment-quality guidelines } \\
\hline Threshold effect concentration (TEC) & -- & none & -- & -- & 423 & 195 & -- \\
\hline Probable effect concentration (PEC) & -- & none & -- & -- & 2,230 & 1,520 & -- \\
\hline \multicolumn{8}{|l|}{ Quality assurance samples } \\
\hline Lab blank & -- & 200503907 & $<10$ & na & $<10$ & $<10$ & na \\
\hline $\begin{array}{l}\text { Lab spike, in percent recovered } \\
\text { (acceptable range) }\end{array}$ & -- & 200503907 & $75.1(57-87)$ & na & $75.0(65-92)$ & $73.4(64-94)$ & na \\
\hline Lab blank & -- & 200504608 & $\mathrm{nr}$ & na & $\mathrm{nr}$ & $\mathrm{nr}$ & na \\
\hline $\begin{array}{l}\text { Lab spike, in percent recovered } \\
\text { (acceptable range) }\end{array}$ & -- & 200504608 & $85.8(57-87)$ & na & $84.4(65-92)$ & $84.8(64-94)$ & na \\
\hline Lab blank & -- & 200506807 & $<10$ & na & $<10$ & $<10$ & na \\
\hline $\begin{array}{l}\text { Lab spike, in percent recovered } \\
\text { (acceptable range) }\end{array}$ & -- & 200506807 & $77.5(57-87)$ & na & $78.9(65-92)$ & $78.8(64-94)$ & na \\
\hline
\end{tabular}


Appendix 2. Analytical results for polycyclic aromatic hydrocarbons from samples collected October 5, 2004, from Devils Swamp Lake, Louisiana-Continued.

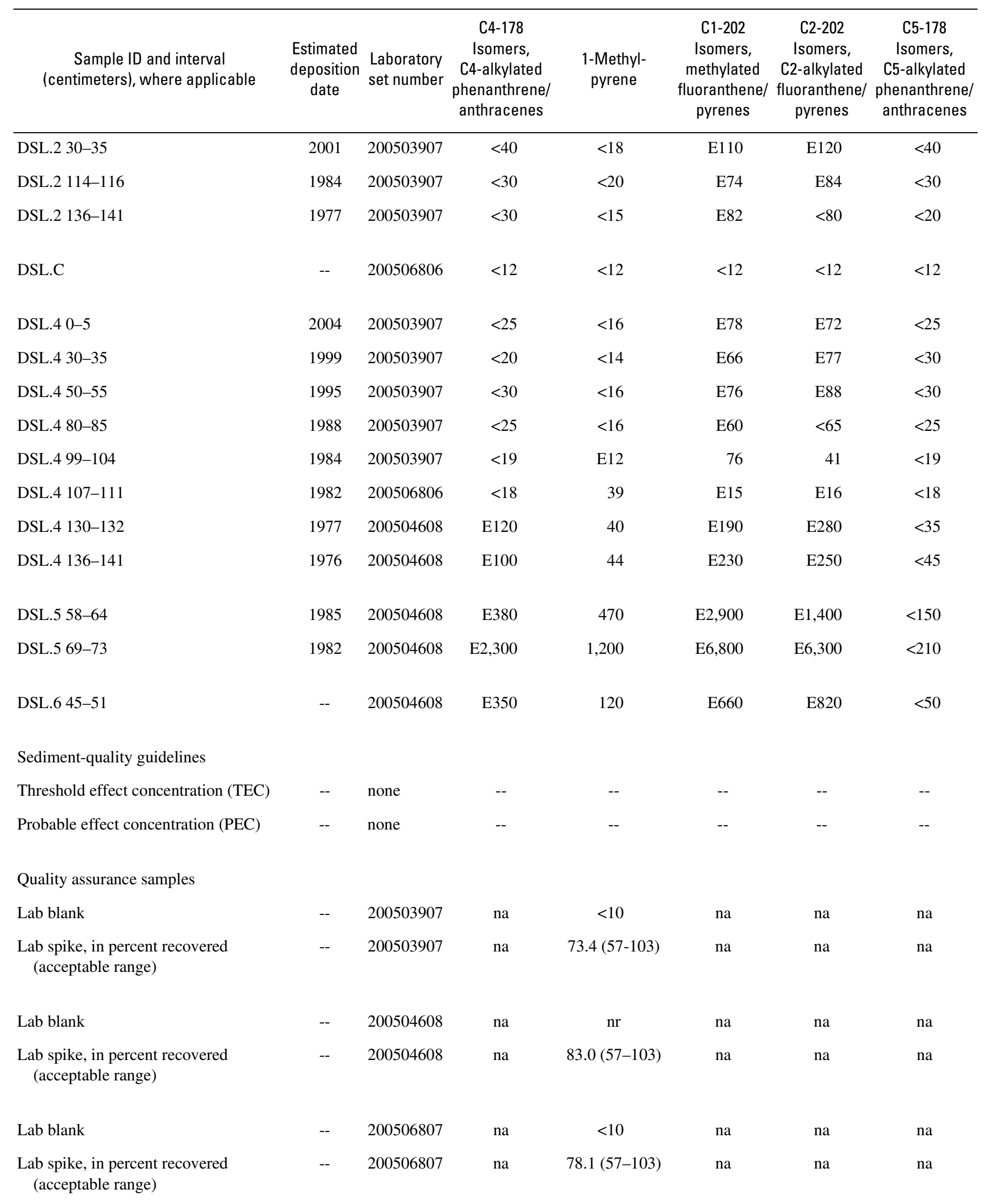


Appendix 2. Analytical results for polycyclic aromatic hydrocarbons from samples collected October 5, 2004, from Devils Swamp Lake, Louisiana-Continued.

\begin{tabular}{|c|c|c|c|c|c|c|}
\hline $\begin{array}{c}\text { Sample ID and interval } \\
\text { (centimeters), where applicable }\end{array}$ & $\begin{array}{l}\text { Estimated } \\
\text { deposition } \\
\text { date }\end{array}$ & $\begin{array}{l}\text { Laboratory } \\
\text { set number }\end{array}$ & $\begin{array}{l}\operatorname{Benz}(a)- \\
\text { anthracene }\end{array}$ & Chrysene & $\begin{array}{c}\text { C3-202 } \\
\text { Isomers, } \\
\text { C3-alkylated } \\
\text { fluoranthene/ } \\
\text { pyrenes }\end{array}$ & $\begin{array}{c}\text { C1-228 } \\
\text { Isomers, } \\
\text { methylated } \\
\text { benzo(a)- } \\
\text { anthracene } \\
\text { chrysenes }\end{array}$ \\
\hline DSL.2 30-35 & 2001 & 200503907 & 51 & 60 & $<80$ & $<100$ \\
\hline DSL.2 114-116 & 1984 & 200503907 & 41 & 40 & $<60$ & $<70$ \\
\hline DSL.2 136-141 & 1977 & 200503907 & 32 & 37 & $<50$ & $<50$ \\
\hline DSL.C & -- & 200506806 & $<12$ & $<12$ & $<12$ & $<12$ \\
\hline DSL.4 0-5 & 2004 & 200503907 & 39 & 44 & $<50$ & $<80$ \\
\hline DSL.4 30-35 & 1999 & 200503907 & 39 & 45 & $<50$ & $<80$ \\
\hline DSL.4 50-55 & 1995 & 200503907 & 42 & 47 & $<55$ & $<80$ \\
\hline DSL.4 80-85 & 1988 & 200503907 & 28 & 31 & $<50$ & $<50$ \\
\hline DSL.4 99-104 & 1984 & 200503907 & 34 & 28 & $<40$ & $<70$ \\
\hline DSL.4 107-111 & 1982 & 200506806 & 40 & 62 & $<18$ & $<18$ \\
\hline DSL.4 130-132 & 1977 & 200504608 & 60 & 80 & $<160$ & $<170$ \\
\hline DSL.4 136-141 & 1976 & 200504608 & 57 & 73 & $<120$ & $<140$ \\
\hline DSL.5 58-64 & 1985 & 200504608 & 570 & 700 & $<490$ & $<720$ \\
\hline DSL.5 69-73 & 1982 & 200504608 & 850 & 1,700 & $\mathrm{E} 2,700$ & $<3,400$ \\
\hline DSL.6 45-51 & -- & 200504608 & 130 & 230 & $<410$ & $<440$ \\
\hline \multicolumn{7}{|l|}{ Sediment-quality guidelines } \\
\hline Threshold effect concentration (TEC) & -- & none & 108 & 166 & -- & -- \\
\hline Probable effect concentration (PEC) & -- & none & 1,050 & 1,290 & -- & -- \\
\hline \multicolumn{7}{|l|}{ Quality assurance samples } \\
\hline Lab blank & -- & 200503907 & $<10$ & $<10$ & na & na \\
\hline Lab spike, in percent recovered (acceptable range) & -- & 200503907 & $73.2(40-115)$ & $73.7(61-94)$ & na & na \\
\hline Lab blank & -- & 200504608 & $\mathrm{nr}$ & $\mathrm{nr}$ & na & na \\
\hline Lab spike, in percent recovered (acceptable range) & -- & 200504608 & $87.9(40-115)$ & 86.9 (61-94) & na & na \\
\hline Lab blank & -- & 200506807 & $<10$ & $<10$ & na & na \\
\hline Lab spike, in percent recovered (acceptable range) & -- & 200506807 & $70.8(40-115)$ & $69.1(61-94)$ & na & na \\
\hline
\end{tabular}


Appendix 2. Analytical results for polycyclic aromatic hydrocarbons from samples collected October 5, 2004, from Devils Swamp Lake, Louisiana-Continued.

\begin{tabular}{|c|c|c|c|c|c|c|c|}
\hline $\begin{array}{c}\text { Sample ID and interval } \\
\text { (centimeters), where applicable }\end{array}$ & $\begin{array}{c}\text { Estimated } \\
\text { deposition } \\
\text { date }\end{array}$ & $\begin{array}{l}\text { Laboratory } \\
\text { set number }\end{array}$ & $\begin{array}{c}\text { C4-202 } \\
\text { Isomers, } \\
\text { C4-alkylated } \\
\text { fluoranthene/ } \\
\text { pyrenes }\end{array}$ & $\begin{array}{c}\text { C5-202 } \\
\text { Isomers, } \\
\text { C5-alkylated } \\
\text { fluoranthene/ } \\
\text { pyrenes }\end{array}$ & $\begin{array}{c}\text { C2-228 } \\
\text { Isomers, } \\
\text { C2-alkylated } \\
\text { benzo(a)- } \\
\text { anthracene/ } \\
\text { chrysenes }\end{array}$ & $\begin{array}{l}\text { Benzo }(b) \text { - } \\
\text { fluoranthene }\end{array}$ & $\begin{array}{l}\text { Benzo(k)- } \\
\text { fluoranthene }\end{array}$ \\
\hline DSL.2 30-35 & 2001 & 200503907 & $<60$ & $<50$ & $<90$ & 40 & 47 \\
\hline DSL.2 114-116 & 1984 & 200503907 & $<50$ & $<50$ & $<60$ & $<20$ & $<20$ \\
\hline DSL.2 136-141 & 1977 & 200503907 & $<40$ & $<30$ & $<40$ & 25 & 34 \\
\hline DSL.C & -- & 200506806 & $<12$ & $<12$ & $<12$ & $<12$ & $<12$ \\
\hline DSL.4 0-5 & 2004 & 200503907 & $<45$ & $<40$ & $<60$ & 31 & 35 \\
\hline DSL.4 30-35 & 1999 & 200503907 & $<40$ & $<40$ & $<60$ & $<14$ & $<14$ \\
\hline DSL.4 50-55 & 1995 & 200503907 & $<50$ & $<50$ & $<60$ & 32 & 37 \\
\hline DSL.4 80-85 & 1988 & 200503907 & $<40$ & $<30$ & $<50$ & $<16$ & $<16$ \\
\hline DSL.4 99-104 & 1984 & 200503907 & $<30$ & $<25$ & $<55$ & E31 & E8.7 \\
\hline DSL.4 107-111 & 1982 & 200506806 & $<18$ & $<18$ & $<18$ & $<18$ & $<18$ \\
\hline DSL.4 130-132 & 1977 & 200504608 & $<70$ & $<50$ & $<160$ & 62 & 33 \\
\hline DSL.4 136-141 & 1976 & 200504608 & $<60$ & $<55$ & $<130$ & 45 & 52 \\
\hline DSL.5 58-64 & 1985 & 200504608 & $<190$ & $<120$ & $<460$ & 260 & 270 \\
\hline DSL.5 69-73 & 1982 & 200504608 & $\mathrm{E} 1,100$ & $<540$ & $<4,000$ & 370 & 350 \\
\hline DSL.6 45-51 & -- & 200504608 & $<190$ & $<80$ & $<440$ & 81 & 73 \\
\hline \multicolumn{8}{|l|}{ Sediment-quality guidelines } \\
\hline Threshold effect concentration (TEC) & -- & none & -- & -- & -- & -- & -- \\
\hline Probable effect concentration (PEC) & -- & none & -- & -- & -- & -- & -- \\
\hline \multicolumn{8}{|l|}{ Quality assurance samples } \\
\hline Lab blank & -- & 200503907 & na & na & na & $<10$ & $<10$ \\
\hline $\begin{array}{l}\text { Lab spike, in percent recovered } \\
\text { (acceptable range) }\end{array}$ & -- & 200503907 & na & na & na & $74.6(49-104)$ & $70.1(40-101)$ \\
\hline Lab blank & -- & 200504608 & na & na & na & $\mathrm{nr}$ & $\mathrm{nr}$ \\
\hline $\begin{array}{l}\text { Lab spike, in percent recovered } \\
\text { (acceptable range) }\end{array}$ & -- & 200504608 & na & na & na & $88.9(49-104)$ & $82.0(40-101)$ \\
\hline Lab blank & -- & 200506807 & na & na & na & $<10$ & $<10$ \\
\hline $\begin{array}{l}\text { Lab spike, in percent recovered } \\
\text { (acceptable range) }\end{array}$ & -- & 200506807 & na & na & na & $64.7(49-104)$ & $62.3(40-101)$ \\
\hline
\end{tabular}


Appendix 2. Analytical results for polycyclic aromatic hydrocarbons from samples collected October 5, 2004, from Devils Swamp Lake, Louisiana-Continued.

\begin{tabular}{|c|c|c|c|c|c|c|c|}
\hline $\begin{array}{c}\text { Sample ID and interval } \\
\text { (centimeters), where applicable }\end{array}$ & $\begin{array}{l}\text { Estimated } \\
\text { deposition } \\
\text { date }\end{array}$ & $\begin{array}{l}\text { Laboratory } \\
\text { set number }\end{array}$ & $\begin{array}{l}\text { Benzo(e)- } \\
\text { pyrene }\end{array}$ & $\begin{array}{l}\text { Benzo(a)- } \\
\text { pyrene }\end{array}$ & Perylene & $\begin{array}{c}\text { C1-252 Isomers, } \\
\text { C1-methylated } \\
\text { benzopyrene/ } \\
\text { perylenes }\end{array}$ & $\begin{array}{c}\text { C3-228 } \\
\text { Isomers, } \\
\text { C3-benzo(a)- } \\
\text { anthracene/ } \\
\text { chrysenes }\end{array}$ \\
\hline DSL.2 30-35 & 2001 & 200503907 & 62 & 67 & 210 & E170 & $<80$ \\
\hline DSL.2 114-116 & 1984 & 200503907 & 50 & 59 & 120 & E120 & $<70$ \\
\hline DSL.2 136-141 & 1977 & 200503907 & 34 & 37 & 44 & $<85$ & $<50$ \\
\hline DSL.C & -- & 200506806 & $<12$ & $<12$ & $<12$ & $<12$ & $<12$ \\
\hline DSL.4 0-5 & 2004 & 200503907 & 48 & 55 & 99 & $<130$ & $<50$ \\
\hline DSL.4 30-35 & 1999 & 200503907 & 50 & 54 & 260 & E140 & $<55$ \\
\hline DSL.4 50-55 & 1995 & 200503907 & 51 & 56 & 330 & E160 & $<60$ \\
\hline DSL.4 80-85 & 1988 & 200503907 & 37 & 44 & 200 & $<100$ & $<45$ \\
\hline DSL.4 99-104 & 1984 & 200503907 & 36 & 35 & 100 & 84 & $<45$ \\
\hline DSL.4 107-111 & 1982 & 200506806 & 51 & 58 & 150 & $<18$ & $<18$ \\
\hline DSL.4 130-132 & 1977 & 200504608 & 60 & 71 & 66 & E170 & $<120$ \\
\hline DSL.4 136-141 & 1976 & 200504608 & 73 & 84 & 100 & E180 & $<120$ \\
\hline DSL.5 58-64 & 1985 & 200504608 & 350 & 490 & 240 & E700 & $<370$ \\
\hline DSL.5 69-73 & 1982 & 200504608 & 570 & 670 & 250 & $\mathrm{E} 1,700$ & $<2,700$ \\
\hline DSL. $645-51$ & -- & 200504608 & 110 & 130 & 330 & E310 & $<380$ \\
\hline \multicolumn{8}{|l|}{ Sediment-quality guidelines } \\
\hline Threshold effect concentration (TEC) & -- & none & -- & 150 & -- & -- & -- \\
\hline Probable effect concentration (PEC) & -- & none & -- & 1,450 & -- & -- & -- \\
\hline \multicolumn{8}{|l|}{ Quality assurance samples } \\
\hline Lab blank & -- & 200503907 & $<10$ & $<10$ & $<10$ & na & na \\
\hline $\begin{array}{l}\text { Lab spike, in percent recovered } \\
\text { (acceptable range) }\end{array}$ & -- & 200503907 & $72.7(35-81)$ & $68.0(26-101)$ & $68.2(53-94)$ & na & na \\
\hline Lab blank & -- & 200504608 & $\mathrm{nr}$ & $\mathrm{nr}$ & $\mathrm{nr}$ & na & na \\
\hline $\begin{array}{l}\text { Lab spike, in percent recovered } \\
\text { (acceptable range) }\end{array}$ & -- & 200504608 & $83.3(35-81)$ & $80.2(26-101)$ & 80.7 (53-94) & na & na \\
\hline Lab blank & -- & 200506807 & $<10$ & $<10$ & $<10$ & na & na \\
\hline $\begin{array}{l}\text { Lab spike, in percent recovered } \\
\text { (acceptable range) }\end{array}$ & -- & 200506807 & $63.1(35-81)$ & $58.4(26-101)$ & $60.0(53-94)$ & na & na \\
\hline
\end{tabular}


Appendix 2. Analytical results for polycyclic aromatic hydrocarbons from samples collected October 5, 2004, from Devils Swamp Lake, Louisiana-Continued.

\begin{tabular}{|c|c|c|c|c|c|c|c|}
\hline $\begin{array}{c}\text { Sample ID and interval } \\
\text { (centimeters), where applicable }\end{array}$ & $\begin{array}{l}\text { Estimated } \\
\text { deposition } \\
\text { date }\end{array}$ & $\begin{array}{l}\text { Laboratory } \\
\text { set number }\end{array}$ & $\begin{array}{c}\text { C2-252 } \\
\text { Isomers, } \\
\text { C2-alkylated } \\
\text { benzo- } \\
\text { pyrene/ } \\
\text { perylenes }\end{array}$ & $\begin{array}{c}\text { C4-228 } \\
\text { Isomers, } \\
\text { C4-benzo(a)- } \\
\text { anthracene/ } \\
\text { chrysenes }\end{array}$ & $\begin{array}{c}\text { Benzo } \\
(g, h, l)- \\
\text { perylene }\end{array}$ & $\begin{array}{c}\text { Indeno- } \\
(1,2,3-c, d)- \\
\text { pyrene }\end{array}$ & $\begin{array}{c}\text { Dibenzo } \\
(a, h)- \\
\text { anthracene }\end{array}$ \\
\hline DSL.2 30-35 & 2001 & 200503907 & $<130$ & $<60$ & 75 & $<18$ & $<18$ \\
\hline DSL.2 114-116 & 1984 & 200503907 & $<90$ & $<70$ & $<20$ & $<20$ & $<20$ \\
\hline DSL.2 136-141 & 1977 & 200503907 & $<50$ & $<30$ & $<15$ & $<15$ & $<15$ \\
\hline DSL.C & -- & 200506806 & $<12$ & $<12$ & $<12$ & $<12$ & $<12$ \\
\hline DSL.4 0-5 & 2004 & 200503907 & $<90$ & $<60$ & $<16$ & $<16$ & $<16$ \\
\hline DSL.4 30-35 & 1999 & 200503907 & $<90$ & $<55$ & 54 & $<14$ & $<14$ \\
\hline DSL.4 50-55 & 1995 & 200503907 & $<95$ & $<60$ & 62 & $<16$ & $<16$ \\
\hline DSL.4 80-85 & 1988 & 200503907 & $<70$ & $<40$ & 44 & $<16$ & $<16$ \\
\hline DSL.4 99-104 & 1984 & 200503907 & $<70$ & $<45$ & 39 & $<19$ & $<19$ \\
\hline DSL.4 107-111 & 1982 & 200506806 & $<18$ & $<18$ & 54 & 26 & $<18$ \\
\hline DSL.4 130-132 & 1977 & 200504608 & $<120$ & $<55$ & 59 & 47 & 36 \\
\hline DSL.4 136-141 & 1976 & 200504608 & $<140$ & $<70$ & 69 & $<15$ & $<15$ \\
\hline DSL.5 58-64 & 1985 & 200504608 & $<350$ & $<140$ & 250 & 210 & 110 \\
\hline DSL.5 69-73 & 1982 & 200504608 & E900 & $<170$ & 250 & $<18$ & $<18$ \\
\hline DSL.6 45-51 & -- & 200504608 & $<230$ & $<70$ & 78 & $<17$ & $<17$ \\
\hline \multicolumn{8}{|l|}{ Sediment-quality guidelines } \\
\hline Threshold effect concentration (TEC) & -- & none & -- & -- & -- & -- & 33 \\
\hline Probable effect concentration (PEC) & -- & none & -- & -- & -- & -- & $\mathrm{nr}$ \\
\hline \multicolumn{8}{|l|}{ Quality assurance samples } \\
\hline Lab blank & -- & 200503907 & na & na & $<10$ & $<10$ & $<10$ \\
\hline $\begin{array}{l}\text { Lab spike, in percent recovered } \\
\text { (acceptable range) }\end{array}$ & -- & 200503907 & na & na & $69.7(37-100)$ & $68.7(31-107)$ & $67.6(21-123)$ \\
\hline Lab blank & -- & 200504608 & na & na & $\mathrm{nr}$ & $\mathrm{nr}$ & $\mathrm{nr}$ \\
\hline $\begin{array}{l}\text { Lab spike, in percent recovered } \\
\text { (acceptable range) }\end{array}$ & -- & 200504608 & na & na & $85.9(37-100)$ & $82.8(31-107)$ & $81.6(21-123)$ \\
\hline Lab blank & -- & 200506807 & na & na & $<10$ & $<10$ & $<10$ \\
\hline $\begin{array}{l}\text { Lab spike, in percent recovered } \\
\text { (acceptable range) }\end{array}$ & -- & 200506807 & na & na & $62.0(37-100)$ & $66.5(31-107)$ & $65.8(21-123)$ \\
\hline
\end{tabular}


Appendix 2. Analytical results for polycyclic aromatic hydrocarbons from samples collected October 5, 2004, from Devils Swamp Lake, Louisiana-Continued.

\begin{tabular}{|c|c|c|c|c|c|c|}
\hline $\begin{array}{c}\text { Sample ID and interval } \\
\text { (centimeters), where applicable }\end{array}$ & $\begin{array}{l}\text { Estimated } \\
\text { deposition } \\
\text { date }\end{array}$ & $\begin{array}{l}\text { Laboratory } \\
\text { set number }\end{array}$ & $\begin{array}{c}\text { C3-252 Isomers, } \\
\text { C3-alkylated } \\
\text { benzopyrene/ } \\
\text { perylenes }\end{array}$ & $\begin{array}{c}\text { C4-252 } \\
\text { Isomers, } \\
\text { C4-alkylated } \\
\text { benzopyrene/ } \\
\text { perylenes }\end{array}$ & $\begin{array}{c}\text { C5-228 Isomers, } \\
\text { C5-benzo(a)- } \\
\text { anthracene/ } \\
\text { chrysenes }\end{array}$ & $\begin{array}{c}\text { C5-252 Isomers, } \\
\text { C5-alkylated } \\
\text { benzopyrene/ } \\
\text { perylenes }\end{array}$ \\
\hline DSL.2 30-35 & 2001 & 200503907 & $<100$ & $<80$ & $<100$ & $<75$ \\
\hline DSL.2 114-116 & 1984 & 200503907 & $<80$ & $<60$ & $<100$ & $<70$ \\
\hline DSL.2 136-141 & 1977 & 200503907 & $<55$ & $<40$ & $<40$ & $<45$ \\
\hline DSL.C & -- & 200506806 & $<12$ & $<12$ & $<12$ & $<12$ \\
\hline DSL.4 0-5 & 2004 & 200503907 & $<70$ & $<60$ & $<90$ & $<60$ \\
\hline DSL.4 30-35 & 1999 & 200503907 & $<70$ & $<50$ & $<80$ & $<60$ \\
\hline DSL.4 50-55 & 1995 & 200503907 & $<90$ & $<55$ & $<90$ & $<70$ \\
\hline DSL.4 80-85 & 1988 & 200503907 & $<65$ & $<50$ & $<65$ & $<55$ \\
\hline DSL.4 99-104 & 1984 & 200503907 & $<45$ & $<30$ & $<55$ & $<35$ \\
\hline DSL.4 107-111 & 1982 & 200506806 & $<18$ & $<18$ & $<18$ & $<18$ \\
\hline DSL.4 130-132 & 1977 & 200504608 & $<120$ & $<60$ & $<65$ & $<65$ \\
\hline DSL.4 136-141 & 1976 & 200504608 & $<120$ & $<75$ & $<80$ & $<65$ \\
\hline DSL.5 58-64 & 1985 & 200504608 & $<270$ & $<150$ & $<140$ & $<170$ \\
\hline DSL.5 69-73 & 1982 & 200504608 & $<940$ & $<470$ & $<290$ & $<120$ \\
\hline DSL.6 45-51 & -- & 200504608 & $<210$ & $<130$ & $<80$ & $<75$ \\
\hline \multicolumn{7}{|l|}{ Sediment-quality guidelines } \\
\hline Threshold effect concentration (TEC) & -- & none & -- & -- & -- & -- \\
\hline Probable effect concentration (PEC) & -- & none & -- & -- & -- & -- \\
\hline \multicolumn{7}{|l|}{ Quality assurance samples } \\
\hline Lab blank & -- & 200503907 & na & na & na & na \\
\hline $\begin{array}{l}\text { Lab spike, in percent recovered } \\
\text { (acceptable range) }\end{array}$ & -- & 200503907 & na & na & na & na \\
\hline Lab blank & -- & 200504608 & na & na & na & na \\
\hline $\begin{array}{l}\text { Lab spike, in percent recovered } \\
\text { (acceptable range) }\end{array}$ & -- & 200504608 & na & na & na & na \\
\hline Lab blank & -- & 200506807 & na & na & na & na \\
\hline $\begin{array}{l}\text { Lab spike, in percent recovered } \\
\text { (acceptable range) }\end{array}$ & -- & 200506807 & na & na & na & na \\
\hline
\end{tabular}




\section{Sources of Polychlorinated Biphenyls to Devils Swamp Lake Near Baton Rouge, Louisiana}

Appendix 2. Analytical results for polycyclic aromatic hydrocarbons from samples collected October 5, 2004, from Devils Swamp Lake, Louisiana-Continued.

\begin{tabular}{|c|c|c|c|c|c|c|c|c|}
\hline \multirow{2}{*}{$\begin{array}{c}\text { Sample ID and interval } \\
\text { (centimeters), where applicable }\end{array}$} & \multirow{2}{*}{$\begin{array}{c}\text { Estimated } \\
\text { deposition } \\
\text { date }\end{array}$} & \multirow{2}{*}{$\begin{array}{l}\text { Laboratory } \\
\text { set number }\end{array}$} & \multicolumn{2}{|c|}{ Calculated values } & \multicolumn{3}{|c|}{$\begin{array}{l}\text { Surrogates, in percent recovered } \\
\text { (acceptable recovery limits) }\end{array}$} & \multirow{2}{*}{$\begin{array}{c}\text { Sample } \\
\text { mass } \\
\text { (grams) }\end{array}$} \\
\hline & & & $\Sigma \mathrm{PAH}_{\mathrm{SOG}}$ & $\begin{array}{l}\text { PAH } 2+3 / \\
\text { comb ratio }\end{array}$ & $\begin{array}{c}\text { 2-Fluoro- } \\
\text { biphenyl } \\
\text { (46-88) }\end{array}$ & $\begin{array}{l}\text { Nitrobenzene- } \\
\text { d5 (46-88) }\end{array}$ & $\begin{array}{c}\text { p-Terphenyl- } \\
\text { d14 } \\
(46-88)\end{array}$ & \\
\hline DSL.2 30-35 & 2001 & 200503907 & 570 & 1.2 & 55 & 44 & 71 & 13.7 \\
\hline DSL.2 114-116 & 1984 & 200503907 & 380 & 1.5 & 55 & 50 & 61 & 12.4 \\
\hline DSL.2 136-141 & 1977 & 200503907 & 410 & .98 & 62 & 58 & 75 & 16.8 \\
\hline DSL.C & -- & 200506806 & 110 & .83 & 65 & 83 & 63 & 20.7 \\
\hline DSL.4 0-5 & 2004 & 200503907 & 360 & 1.1 & 58 & 52 & 62 & 15.4 \\
\hline DSL.4 30-35 & 1999 & 200503907 & 330 & .96 & 61 & 63 & 70 & 17.4 \\
\hline DSL.4 50-55 & 1995 & 200503907 & 370 & .85 & 62 & 55 & 67 & 15.7 \\
\hline DSL.4 80-85 & 1988 & 200503907 & 290 & 1.5 & 57 & 53 & 61 & 16.0 \\
\hline DSL.4 99-104 & 1984 & 200503907 & 320 & .16 & 66 & 78 & 69 & 15.0 \\
\hline DSL.4 107-111 & 1982 & 200506806 & 570 & .28 & 64 & 84 & 56 & 13.8 \\
\hline DSL.4 130-132 & 1977 & 200504608 & 980 & 2.0 & 49 & 42 & 57 & 15.6 \\
\hline DSL.4 136-141 & 1976 & 200504608 & 1,100 & 1.6 & 57 & 59 & 69 & 16.9 \\
\hline DSL.5 58-64 & 1985 & 200504608 & 11,000 & 1.2 & 58 & 54 & 71 & 8.7 \\
\hline DSL.5 69-73 & 1982 & 200504608 & 16,000 & 4.0 & 69 & 76 & 102 & 14.2 \\
\hline DSL.6 45-51 & -- & 200504608 & 2,000 & 1.5 & 67 & 59 & 73 & 14.3 \\
\hline \multicolumn{9}{|l|}{ Sediment-quality guidelines } \\
\hline Threshold effect concentration (TEC) & -- & none & 1,610 & -- & -- & -- & -- & -- \\
\hline Probable effect concentration (PEC) & -- & none & 22,800 & -- & -- & -- & -- & -- \\
\hline \multicolumn{9}{|l|}{ Quality assurance samples } \\
\hline Lab blank & -- & 200503907 & -- & -- & 59 & 55 & 65 & 25.0 \\
\hline $\begin{array}{l}\text { Lab spike, in percent recovered } \\
\text { (acceptable range) }\end{array}$ & -- & 200503907 & -- & -- & 67 & 60 & 69 & 25.0 \\
\hline Lab blank & -- & 200504608 & -- & -- & $\mathrm{nr}$ & $\mathrm{nr}$ & $\mathrm{nr}$ & $\mathrm{nr}$ \\
\hline $\begin{array}{l}\text { Lab spike, in percent recovered } \\
\text { (acceptable range) }\end{array}$ & -- & 200504608 & -- & -- & 59 & 59 & 81 & 25.0 \\
\hline Lab blank & -- & 200506807 & -- & -- & 47 & 56 & 94 & 25.0 \\
\hline $\begin{array}{l}\text { Lab spike, in percent recovered } \\
\text { (acceptable range) }\end{array}$ & -- & 200506807 & -- & -- & 68 & 56 & 74 & 25.0 \\
\hline
\end{tabular}


Appendix 3-Analytical Results for

Major and Trace Elements 
Blank Page 
Appendix 3. Analytical results for major and trace elements from samples collected October 5, 2004, from Devils Swamp Lake, Louisiana.

[In micrograms per gram except as indicated. Concentration in bold exceeds probable effect concentration (MacDonald and others, 2000). ID, identifier; --, not calculated; SRMs, standard reference materials; nr, not reported; <, nondetection at indicated value]

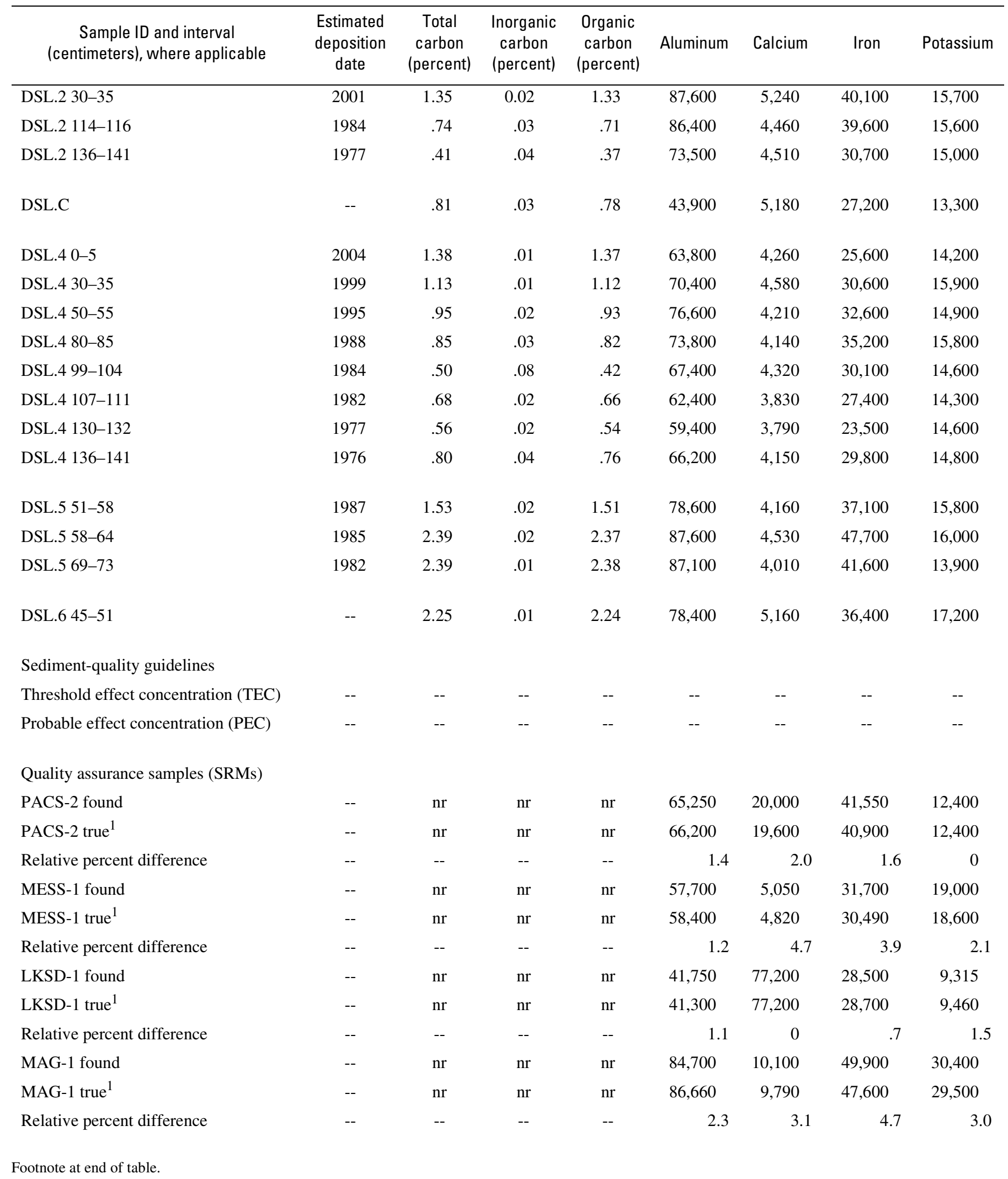


Appendix 3. Analytical results for major and trace elements from samples collected October 5, 2004, from Devils Swamp Lake, Louisiana-Continued.

\begin{tabular}{|c|c|c|c|c|c|c|c|c|}
\hline $\begin{array}{c}\text { Sample ID and interval } \\
\text { (centimeters), where applicable }\end{array}$ & $\begin{array}{l}\text { Estimated } \\
\text { deposition } \\
\text { date }\end{array}$ & Magnesium & Sodium & Phosphorus & Titanium & Arsenic & Barium & Beryllium \\
\hline DSL.2 30-35 & 2001 & 7,290 & 4,070 & 1,110 & 4,260 & 12.7 & 612 & 2.1 \\
\hline DSL.2 114-116 & 1984 & 7,030 & 8,310 & 854 & 4,480 & 15.3 & 564 & 2.1 \\
\hline DSL.2 136-141 & 1977 & 5,780 & 7,760 & 780 & 4,150 & 10.1 & 546 & 1.8 \\
\hline DSL.C & -- & 3,520 & 5,960 & 694 & 3,090 & 12.4 & 710 & 1.9 \\
\hline DSL.4 0-5 & 2004 & 4,800 & 5,720 & 830 & 3,850 & 12.6 & 563 & 1.5 \\
\hline DSL.4 30-35 & 1999 & 5,810 & 6,040 & 922 & 4,350 & 10.2 & 598 & 1.8 \\
\hline DSL.4 50-55 & 1995 & 5,990 & 5,730 & 912 & 4,010 & 10.4 & 555 & 1.8 \\
\hline DSL.4 80-85 & 1988 & 6,440 & 7,010 & 1,390 & 3,900 & 11.7 & 573 & 1.8 \\
\hline DSL.4 99-104 & 1984 & 5,330 & 7,170 & 873 & 3,790 & 8.2 & 529 & 1.7 \\
\hline DSL.4 107-111 & 1982 & 5,070 & 7,060 & 995 & 3,830 & 9.0 & 546 & 1.5 \\
\hline DSL.4 130-132 & 1977 & 4,720 & 7,440 & 742 & 3,630 & 9.6 & 560 & 1.6 \\
\hline DSL.4 136-141 & 1976 & 5,610 & 7,020 & 1,090 & 3,980 & 11.4 & 592 & 1.7 \\
\hline DSL.5 51-58 & 1987 & 6,670 & 5,660 & 1,290 & 4,710 & 17.2 & 657 & 2.1 \\
\hline DSL.5 58-64 & 1985 & 7,780 & 5,500 & 1,560 & 4,710 & 23.2 & 992 & 2.5 \\
\hline DSL.5 69-73 & 1982 & 6,270 & 5,790 & 932 & 4,110 & 18.9 & 695 & 2.0 \\
\hline DSL.6 45-51 & -- & 7,130 & 5,620 & 1,610 & 4,140 & 17.6 & 763 & 2.2 \\
\hline \multicolumn{9}{|l|}{ Sediment-quality guidelines } \\
\hline Threshold effect concentration (TEC) & -- & -- & -- & -- & -- & 9.79 & -- & -- \\
\hline Probable effect concentration (PEC) & -- & -- & -- & -- & -- & 33 & -- & -- \\
\hline \multicolumn{9}{|l|}{ Quality assurance samples (SRMs) } \\
\hline PACS-2 found & -- & 14,850 & 34,600 & 1,013 & 4,675 & 26.9 & 925 & 1.2 \\
\hline PACS-2 true ${ }^{1}$ & -- & 14,700 & 34,500 & 960 & 4,430 & 26.2 & $\mathrm{nr}$ & 1.0 \\
\hline Relative percent difference & -- & 1.0 & .3 & 5.4 & 5.4 & 2.6 & -- & 18.2 \\
\hline MESS-1 found & -- & 9,020 & 18,200 & 705 & 4,210 & 11.0 & 308 & 2.4 \\
\hline MESS-1 true ${ }^{1}$ & -- & 8,690 & 18,500 & 637 & 5,430 & 10.6 & $\mathrm{nr}$ & 1.9 \\
\hline Relative percent difference & -- & 3.7 & 1.6 & 10.1 & 25.3 & 3.7 & -- & 23.3 \\
\hline LKSD-1 found & -- & 10,500 & 14,800 & 751 & 2,885 & 35.9 & 414 & .86 \\
\hline LKSD-1 true ${ }^{1}$ & -- & 10,400 & 14,800 & 698 & 3,180 & 40.0 & 430 & 1.1 \\
\hline Relative percent difference & -- & 1.0 & 0 & 7.2 & 9.7 & 10.8 & 3.8 & 24.5 \\
\hline MAG-1 found & -- & 18,700 & 28,400 & 726 & 4,380 & 10.1 & 502 & 3.2 \\
\hline MAG-1 true ${ }^{1}$ & -- & 18,090 & 28,400 & 711 & 4,500 & 9.2 & 479 & 3.2 \\
\hline Relative percent difference & -- & 3.3 & 0 & 2.1 & 2.7 & 9.3 & 4.7 & 0 \\
\hline
\end{tabular}


Appendix 3. Analytical results for major and trace elements from samples collected October 5, 2004, from Devils Swamp Lake, Louisiana-Continued.

\begin{tabular}{|c|c|c|c|c|c|c|c|c|}
\hline $\begin{array}{c}\text { Sample ID and interval } \\
\text { (centimeters), where applicable }\end{array}$ & $\begin{array}{l}\text { Estimated } \\
\text { deposition } \\
\text { date }\end{array}$ & Cadmium & Cobalt & Chromium & Copper & Mercury & Lithium & Manganese \\
\hline DSL.2 30-35 & 2001 & 1.9 & 12.9 & 84.3 & 29.4 & 0.11 & 43.8 & 965 \\
\hline DSL.2 114-116 & 1984 & 6.0 & 13.3 & 86.4 & 38.5 & .66 & 45.2 & 461 \\
\hline DSL.2 136-141 & 1977 & 2.6 & 11.5 & 69.4 & 35.3 & .65 & 37.5 & 273 \\
\hline DSL.C & -- & .32 & 16.6 & 46.7 & 19.3 & .08 & 23.3 & 1,000 \\
\hline DSL.4 0-5 & 2004 & 5.3 & 10.7 & 58.7 & 23.2 & .08 & 29.0 & 454 \\
\hline DSL.4 30-35 & 1999 & 6.6 & 12.4 & 66.4 & 25.1 & .08 & 35.1 & 575 \\
\hline DSL.4 50-55 & 1995 & 4.0 & 11.5 & 66.1 & 25.6 & .12 & 35.4 & 734 \\
\hline DSL.4 80-85 & 1988 & 3.9 & 11.9 & 74.6 & 33.3 & 1.0 & 38.5 & 839 \\
\hline DSL.4 99-104 & 1984 & 3.1 & 9.8 & 64.0 & 29.4 & .45 & 33.4 & 697 \\
\hline DSL.4 107-111 & 1982 & 5.8 & 10.7 & 72.6 & 29.9 & 1.3 & 33.2 & 487 \\
\hline DSL.4 130-132 & 1977 & 4.3 & 15.2 & 56.2 & 49.0 & .86 & 28.6 & 413 \\
\hline DSL.4 136-141 & 1976 & 7.4 & 12.1 & 79.5 & 70.7 & .98 & 32.4 & 685 \\
\hline DSL.5 51-58 & 1987 & 19.1 & 15.7 & 91.9 & 63.0 & .62 & 43.9 & 771 \\
\hline DSL.5 58-64 & 1985 & 20.8 & 19.0 & 135 & 44.0 & .16 & 50.9 & 850 \\
\hline DSL.5 69-73 & 1982 & 9.5 & 32.1 & 92.8 & 57.0 & .15 & 42.2 & 517 \\
\hline DSL.6 45-51 & -- & 11.9 & 15.7 & 90.4 & 33.0 & .11 & 40.8 & 844 \\
\hline \multicolumn{9}{|l|}{ Sediment-quality guidelines } \\
\hline Threshold effect concentration (TEC) & -- & .99 & -- & 43.4 & 31.6 & .18 & -- & -- \\
\hline Probable effect concentration (PEC) & -- & 4.98 & -- & 111 & 149 & 1.06 & -- & -- \\
\hline \multicolumn{9}{|l|}{ Quality assurance samples (SRMs) } \\
\hline PACS-2 found & -- & 2.3 & 11.8 & 88.4 & 300 & $\mathrm{nr}$ & 30.7 & 440 \\
\hline PACS-2 true ${ }^{1}$ & -- & 2.1 & 11.5 & 90.7 & 310 & $\mathrm{nr}$ & 32.2 & 440 \\
\hline Relative percent difference & -- & 8.6 & 2.6 & 2.6 & 3.4 & -- & 4.8 & .1 \\
\hline MESS-1 found & -- & .7 & 12.1 & 58.2 & 28.2 & $\mathrm{nr}$ & 43.9 & 522 \\
\hline MESS- 1 true ${ }^{1}$ & -- & .6 & 10.8 & 71.0 & 25.1 & $\mathrm{nr}$ & 44.9 & 512 \\
\hline Relative percent difference & -- & 14.2 & 11.4 & 19.8 & 11.6 & -- & 2.3 & 1.9 \\
\hline LKSD-1 found & -- & 1.4 & 10.5 & 28.3 & 43.6 & $\mathrm{nr}$ & 6.5 & 688 \\
\hline LKSD-1 true ${ }^{1}$ & -- & $\mathrm{nr}$ & 11.0 & 31.0 & 44.0 & $\mathrm{nr}$ & 7.0 & 697 \\
\hline Relative percent difference & -- & -- & 5.1 & 9.1 & .9 & -- & 8.2 & 1.4 \\
\hline MAG-1 found & -- & .2 & 22.4 & 106 & 30.7 & $\mathrm{nr}$ & 79.3 & 777 \\
\hline MAG-1 true ${ }^{1}$ & -- & .2 & 20.4 & 97.0 & 30.0 & $\mathrm{nr}$ & 79.0 & 760 \\
\hline Relative percent difference & -- & 0 & 9.3 & 8.9 & 2.3 & -- & .4 & 2.2 \\
\hline
\end{tabular}


Appendix 3. Analytical results for major and trace elements from samples collected October 5, 2004, from Devils Swamp Lake, Louisiana-Continued.

\begin{tabular}{|c|c|c|c|c|c|c|c|c|}
\hline $\begin{array}{c}\text { Sample ID and interval } \\
\text { (centimeters), where applicable }\end{array}$ & $\begin{array}{l}\text { Estimated } \\
\text { deposition } \\
\text { date }\end{array}$ & Nickel & Lead & Scandium & Strontium & Vanadium & Zinc & Antimony \\
\hline DSL.2 30-35 & 2001 & 36.8 & 48.3 & 14.0 & 86.7 & 118 & 134 & 2.6 \\
\hline DSL. 2 114-116 & 1984 & 36.9 & 74.2 & 14.2 & 87.1 & 118 & 170 & 7.2 \\
\hline DSL.2 136-141 & 1977 & 33.4 & 37.9 & 11.7 & 87.7 & 96.0 & 149 & 5.5 \\
\hline DSL.C & -- & 25.8 & 30.7 & 7.4 & 89.8 & 83.4 & 79.9 & .97 \\
\hline DSL.4 0-5 & 2004 & 26.1 & 77.6 & 9.8 & 87.4 & 81.5 & 107 & 3.9 \\
\hline DSL.4 30-35 & 1999 & 28.6 & 62.6 & 11.4 & 91.2 & 94.2 & 122 & 3.6 \\
\hline DSL.4 50-55 & 1995 & 28.7 & 48.2 & 12.0 & 80.5 & 96.3 & 112 & 3.1 \\
\hline DSL.4 80-85 & 1988 & 30.5 & 54.7 & 12.4 & 86.1 & 103 & 143 & 12.0 \\
\hline DSL.4 99-104 & 1984 & 28.3 & 40.4 & 10.6 & 88.4 & 92.4 & 136 & 3.9 \\
\hline DSL.4 107-111 & 1982 & 28.4 & 54.4 & 9.9 & 85.2 & 86.0 & 135 & 5.5 \\
\hline DSL.4 130-132 & 1977 & 35.0 & 78.6 & 9.0 & 88.8 & 75.4 & 158 & 3.0 \\
\hline DSL.4 136-141 & 1976 & 40.2 & 78.0 & 10.7 & 91.0 & 95.0 & 161 & 4.1 \\
\hline DSL.5 51-58 & 1987 & 52.1 & 134 & 13.4 & 83.7 & 116 & 196 & 8.1 \\
\hline DSL.5 58-64 & 1985 & 128 & 176 & 15.4 & 84.6 & 144 & 234 & 13.9 \\
\hline DSL.5 69-73 & 1982 & 158 & 223 & 13.9 & 78.4 & 110 & 371 & 11.3 \\
\hline DSL.6 45-51 & -- & 78.1 & 121 & 13.0 & 109 & 125 & 171 & 10.7 \\
\hline \multicolumn{9}{|l|}{ Sediment-quality guidelines } \\
\hline Threshold effect concentration (TEC) & -- & 22.7 & 35.8 & -- & -- & -- & 121 & -- \\
\hline Probable effect concentration (PEC) & -- & 48.6 & 128 & -- & -- & -- & 459 & -- \\
\hline \multicolumn{9}{|l|}{ Quality assurance samples (SRMs) } \\
\hline PACS-2 found & -- & 37.7 & 176 & 14.7 & 278 & 135 & 367 & 11.4 \\
\hline PACS-2 true ${ }^{1}$ & -- & 39.5 & 183 & $\mathrm{nr}$ & 276 & 133 & 364 & 11.3 \\
\hline Relative percent difference & -- & 4.7 & 3.9 & -- & .7 & 1.5 & .8 & .9 \\
\hline MESS-1 found & -- & 27.3 & 34.8 & 10.9 & 88.3 & 76.2 & 191 & .73 \\
\hline MESS-1 true ${ }^{1}$ & -- & 29.5 & 34.0 & $\mathrm{nr}$ & $\mathrm{nr}$ & 72.4 & 191 & .73 \\
\hline Relative percent difference & -- & 7.7 & 2.3 & -- & -- & 5.1 & 0 & 0 \\
\hline LKSD-1 found & -- & 16.0 & 89.1 & 8.3 & 268 & 49.4 & 327 & .98 \\
\hline LKSD-1 true ${ }^{1}$ & -- & 16.0 & 82.0 & 9.0 & 250 & 50.0 & 331 & 1.2 \\
\hline Relative percent difference & -- & 0 & 8.3 & 8.7 & 6.8 & 1.2 & 1.4 & 20.2 \\
\hline MAG-1 found & -- & 49.2 & 28.1 & 18.6 & 143 & 143 & 137 & .94 \\
\hline MAG-1 true ${ }^{1}$ & -- & 53.0 & 24.0 & 17.2 & 146 & 140 & 130 & .96 \\
\hline Relative percent difference & -- & 7.4 & 15.7 & 7.8 & 2.1 & 2.1 & 5.2 & 2.1 \\
\hline
\end{tabular}


Appendix 3. Analytical results for major and trace elements from samples collected October 5, 2004, from Devils Swamp Lake, Louisiana-Continued.

\begin{tabular}{|c|c|c|c|c|c|c|c|c|c|}
\hline $\begin{array}{c}\text { Sample ID and interval } \\
\text { (centimeters), where applicable }\end{array}$ & $\begin{array}{l}\text { Estimated } \\
\text { deposition } \\
\text { date }\end{array}$ & Bismuth & Cerium & Cesium & Gallium & $\begin{array}{l}\text { Lan- } \\
\text { thanum }\end{array}$ & $\begin{array}{l}\text { Moly- } \\
\text { bdenum }\end{array}$ & $\begin{array}{l}\text { Rubid- } \\
\text { ium }\end{array}$ & Niobium \\
\hline DSL.2 30-35 & 2001 & 0.30 & 77.9 & 7.3 & 19.0 & 42.0 & 1.3 & 96.2 & 21 \\
\hline DSL.2 114-116 & 1984 & .35 & 80.1 & 26.4 & 19.2 & 46.0 & 9.9 & 97.3 & 23 \\
\hline DSL.2 136-141 & 1977 & .42 & 69.5 & 18.4 & 16.1 & 40.3 & 3.1 & 83.3 & 21 \\
\hline DSL.C & -- & .21 & 88.0 & 3.1 & 10.7 & 32.5 & 1.4 & 59.8 & 11 \\
\hline DSL.4 0-5 & 2004 & .22 & 69.0 & 4.2 & 13.6 & 36.8 & .93 & 73.8 & 18 \\
\hline DSL.4 30-35 & 1999 & .24 & 73.4 & 5.0 & 15.8 & 39.7 & 1.0 & 84.9 & 21 \\
\hline DSL.4 50-55 & 1995 & .27 & 68.7 & 8.6 & 16.1 & 38.3 & 1.1 & 84.2 & 18 \\
\hline DSL.4 80-85 & 1988 & .30 & 70.0 & 25.2 & 17.0 & 39.7 & 3.0 & 91.0 & 19 \\
\hline DSL.4 99-104 & 1984 & .36 & 66.7 & 14.7 & 14.6 & 36.8 & 2.0 & 77.1 & 16 \\
\hline DSL.4 107-111 & 1982 & .37 & 62.6 & 11.1 & 14.6 & 34.6 & 2.2 & 75.6 & 16 \\
\hline DSL.4 130-132 & 1977 & .58 & 59.8 & 4.5 & 13.4 & 34.2 & 1.5 & 71.7 & 16 \\
\hline DSL.4 136-141 & 1976 & .35 & 67.9 & 4.6 & 15.9 & 37.1 & 1.4 & 81.5 & 18 \\
\hline DSL.5 51-58 & 1987 & .36 & 80.0 & 5.6 & 18.7 & 43.6 & 2.3 & 95.4 & 21 \\
\hline DSL.5 58-64 & 1985 & .36 & 83.8 & 6.6 & 21.1 & 45.7 & 5.0 & 103 & 25 \\
\hline DSL.5 69-73 & 1982 & .29 & 76.1 & 5.4 & 18.4 & 44.6 & 12.3 & 89.8 & 21 \\
\hline DSL.6 45-51 & -- & .30 & 81.3 & 5.8 & 17.9 & 42.2 & 2.2 & 97.9 & 20 \\
\hline \multicolumn{10}{|l|}{ Sediment-quality guidelines } \\
\hline Threshold effect concentration (TEC) & -- & -- & -- & -- & -- & -- & -- & -- & -- \\
\hline Probable effect concentration (PEC) & -- & -- & -- & -- & -- & -- & -- & -- & -- \\
\hline \multicolumn{10}{|l|}{ Quality assurance samples (SRMs) } \\
\hline PACS-2 found & -- & .34 & 32.0 & 2.1 & 13.6 & 16.0 & 5.3 & 42.0 & 11.0 \\
\hline PACS-2 true ${ }^{1}$ & -- & $\mathrm{nr}$ & $\mathrm{nr}$ & $\mathrm{nr}$ & $\mathrm{nr}$ & $\mathrm{nr}$ & 5.4 & $\mathrm{nr}$ & $\mathrm{nr}$ \\
\hline Relative percent difference & -- & -- & -- & -- & -- & -- & 3.4 & -- & -- \\
\hline MESS-1 found & -- & .33 & 74.4 & 4.2 & 13.5 & 39 & 2.3 & 94.7 & 17.0 \\
\hline MESS- 1 true ${ }^{1}$ & -- & $\mathrm{nr}$ & $\mathrm{nr}$ & $\mathrm{nr}$ & $\mathrm{nr}$ & $\mathrm{nr}$ & $\mathrm{nr}$ & $\mathrm{nr}$ & $\mathrm{nr}$ \\
\hline Relative percent difference & -- & -- & -- & -- & -- & -- & -- & -- & -- \\
\hline LKSD-1 found & -- & .87 & 26.6 & .69 & 8.8 & 15.2 & 9.6 & 23.0 & 4.4 \\
\hline LKSD-1 true ${ }^{1}$ & -- & $\mathrm{nr}$ & 27.0 & $\mathrm{nr}$ & $\mathrm{nr}$ & 16.0 & 10.0 & 24.0 & $\mathrm{nr}$ \\
\hline Relative percent difference & -- & -- & 1.5 & -- & -- & 5.5 & 4.1 & 4.5 & -- \\
\hline MAG-1 found & -- & .36 & 86.5 & 8.4 & 22.3 & 43.4 & 1.1 & 154 & 22.0 \\
\hline MAG-1 true ${ }^{1}$ & -- & .34 & 88.0 & 8.6 & 20.4 & 43.0 & 1.6 & 149 & 12.0 \\
\hline Relative percent difference & -- & 5.7 & 1.7 & 2.4 & 8.9 & .9 & 37.0 & 3.3 & 58.8 \\
\hline
\end{tabular}


Appendix 3. Analytical results for major and trace elements from samples collected October 5, 2004, from Devils Swamp Lake, Louisiana-Continued.

\begin{tabular}{|c|c|c|c|c|c|c|c|}
\hline $\begin{array}{c}\text { Sample ID and interval } \\
\text { (centimeters), where applicable }\end{array}$ & $\begin{array}{l}\text { Estimated } \\
\text { deposition } \\
\text { date }\end{array}$ & Silver & Tantalum & Thallium & Thorium & Uranium & Yttrium \\
\hline DSL.2 30-35 & 2001 & $<2$ & 4.2 & 1.00 & 12.6 & 3.34 & 29.1 \\
\hline DSL.2 114-116 & 1984 & 2.6 & 3.6 & 2.22 & 12.8 & 2.92 & 31.3 \\
\hline DSL.2 136-141 & 1977 & $<2$ & 3.0 & 1.35 & 11.6 & 2.74 & 26.8 \\
\hline DSL.C & -- & $<2$ & .31 & .52 & 9.46 & 2.29 & 23.0 \\
\hline DSL.4 0-5 & 2004 & $<2$ & 2.4 & .80 & 10.6 & 2.76 & 25.9 \\
\hline DSL.4 30-35 & 1999 & $<2$ & 2.7 & .95 & 11.6 & 3.04 & 30.6 \\
\hline DSL.4 50-55 & 1995 & $<2$ & .95 & .94 & 11.5 & 2.88 & 27.3 \\
\hline DSL.4 80-85 & 1988 & 2.1 & 1.2 & 3.34 & 11.7 & 2.88 & 27.0 \\
\hline DSL.4 99-104 & 1984 & $<2$ & .81 & .96 & 10.8 & 2.67 & 25.8 \\
\hline DSL.4 107-111 & 1982 & $<2$ & .83 & 1.51 & 10.6 & 2.72 & 24.2 \\
\hline DSL.4 130-132 & 1977 & $<2$ & .68 & 1.55 & 10.4 & 2.46 & 23.3 \\
\hline DSL.4 136-141 & 1976 & $<2$ & .93 & .92 & 11.0 & 2.73 & 25.9 \\
\hline DSL.5 51-58 & 1987 & $<2$ & 1.4 & 1.26 & 12.4 & 3.10 & 30.7 \\
\hline DSL.5 58-64 & 1985 & $<2$ & 7.2 & 1.92 & 13.2 & 3.35 & 32.2 \\
\hline DSL.5 69-73 & 1982 & $<2$ & 4.9 & 1.92 & 12.4 & 2.96 & 32.4 \\
\hline DSL.6 45-51 & -- & $<2$ & 1.4 & 1.62 & 12.3 & 3.29 & 29.3 \\
\hline \multicolumn{8}{|l|}{ Sediment-quality guidelines } \\
\hline Threshold effect concentration (TEC) & -- & -- & -- & -- & -- & -- & -- \\
\hline Probable effect concentration (PEC) & -- & -- & -- & -- & -- & -- & -- \\
\hline \multicolumn{8}{|l|}{ Quality assurance samples (SRMs) } \\
\hline PACS-2 found & -- & $<2$ & .34 & .62 & 4.19 & 2.44 & 17.4 \\
\hline PACS- 2 true ${ }^{1}$ & -- & 1.2 & $\mathrm{nr}$ & .60 & $\mathrm{nr}$ & $\mathrm{nr}$ & $\mathrm{nr}$ \\
\hline Relative percent difference & -- & -- & -- & 2.5 & -- & -- & -- \\
\hline MESS-1 found & -- & $<2$ & 1.2 & .65 & 12.8 & 3.65 & 25.5 \\
\hline MESS-1 true ${ }^{1}$ & -- & $\mathrm{nr}$ & $\mathrm{nr}$ & $\mathrm{nr}$ & $\mathrm{nr}$ & $\mathrm{nr}$ & $\mathrm{nr}$ \\
\hline Relative percent difference & -- & -- & -- & -- & -- & -- & -- \\
\hline LKSD-1 found & -- & $<2$ & $\mathrm{nr}$ & .35 & 2.05 & 9.61 & 21.9 \\
\hline LKSD-1 true ${ }^{1}$ & -- & .6 & .30 & $\mathrm{nr}$ & 2.20 & 9.70 & 19.0 \\
\hline Relative percent difference & -- & -- & -- & -- & 7.3 & 1.0 & 14.0 \\
\hline MAG-1 found & -- & $<2$ & 1.9 & .76 & 12.60 & 2.81 & 24.6 \\
\hline MAG-1 true ${ }^{1}$ & -- & .1 & 1.1 & $\mathrm{nr}$ & 11.9 & 2.70 & 28.0 \\
\hline Relative percent difference & -- & -- & 52.5 & -- & 5.7 & 4.0 & 12.9 \\
\hline
\end{tabular}

${ }^{1}$ True concentrations in SRM samples from Potts and others (1992). 
Prepared by the USGS Texas Water Science Center:

8027 Exchange Drive

Austin, TX 78754-4733

Information regarding water resources in Texas is available at http: //tx.usgs.gov/ 